\title{
Formation of cryolite and other aluminofluorides: A petrologic review
}

\author{
J. C. BAILEY
}

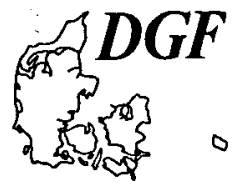

Bailey, J. C.: Formation of cryolite and other aluminofluorides: A petrologic review. Bull. geol. Soc. Denmark, vol. 29, pp. 1-45. Copenhagen, June 10th, 1980. https://doi.org/10.37570/bgsd-1980-29-01

Petrologic reviews are provided for 17 confirmed localities of cryolite, and for occurrences of 19 other aluminofluorides. Four environments can be recognised: granitic, carbonatitic, volcanic and aqueous.

Cryolite, partly replaced by other aluminofluorides, forms at the post-magmatic stage of granite evolu-tion in alkali granite pegmatites, albitised riebeckite granites and hydrothermal bodies. The associated magmatic granites are post- or non-orogenic, late intrusions often associated with regional faulting. They are rich in $\mathrm{Na}$ and $\mathrm{F}$, poor in $\mathrm{Ca}$, and low in normative anorthite, acmite and sodium silicate. High contents of $\mathrm{Rb}, \mathrm{Zr}, \mathrm{Nb}, \mathrm{REE}$ and $\mathrm{Li}$ are characteristic. They equilibrated at $1-2 \mathrm{~kb} \mathrm{P} \mathrm{H}_{2} \mathrm{O}$ in agreement with their epizonal setting. Experiments in the granite- $\mathrm{H}_{2} \mathrm{O}-\mathrm{HF}$ system develop aluminofluorides in coexisting dense vapours. Equivalent fluids cooled to multi-phase inclusions in the Volyn pegmatites, Ukraine, and contain cryolite and elpasolite. Post-magmatic autometasomatism extracts and then redeposits $\mathrm{F}, \mathrm{Na}$ and other elements probably via. fluids containing fluoriferous complex ions. Quartz-feldspar metasomatites in E Siberia are related to regional metamorphism and deep faulting.

Rare carbonatites and silico-carbonatites with high contents of $\mathrm{Na}$ concentrate $\mathrm{F}$ in late hydrothermal solutions and produced cryolite at Goldie, Colorado and Francon quarry, Montreal.

Ralstonite is widely reported, and elpasolite and weberite rarely reported, from fumaroles and HF-metasomatised lavas of basic to intermediate volcanoes. Deposition occurred at $300-100^{\circ} \mathrm{C}$. Thermal springs and surface runoff froin volcanoes carry relatively high $\mathrm{F}$ contents and occasionally form gearksu-tite and creedite by reaction with aluminosilicate materials.

Cryolite is a rare authigenic mineral in sediments of the Green River Formation, W USA. F-rich interstitial brines, developed as in the modern Lake Magadi, Kenya, probably reacted with the host aluminosilicate sediments. Gearksutite and creedite, plus five other recently discovered aluminofluorides, occur within or just. below the oxidation zones, or in the weathering crusts, of some F-rich mineral deposits. Low-temperature precipitated aluminofluorides have been produced synthetically but are un-known in nature.

The only economic aluminofluoride, cryolite, was present as several million tons at Ivigtut, $S$

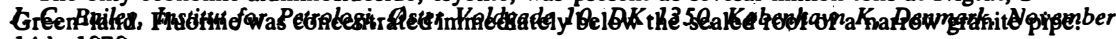
14 th, 1979.

Дж. К. Бэйли: Образование криолита и других алюмофторидов (петрологический обзор) Бюллетень Геологического Общества Дании, т. 29, стр. 1-45. Копенгаген, 1980.

Имеющиеся петрологические обзоры охватывают 17 установленных минерализацић криолита и проявления 19 других алюмофторидов. Различают четыре типа обстановки их образования: гранитный, кафбонатитовый, вулканнческий и водный.

Криолит, частично замещенный другими алюмофторидами, образуется в постмафматическую стадию гранитной эволюции в щелочньх гранитных пегматитах, альбитизированньх рибехитовых гранитах и гидротермальных телах. Связанные с ним магматические граниты представляют собой после - или неорогенитеские интрузии, связанные с региональными тектоническими нарутениями. Эти граниты богаты $\mathrm{Na}$ и $\mathrm{F}$, но бедны $\mathrm{Ca}$; для них характерны низкое содержание нормативных анортита, акмита и натриевого силиката и высокое содержание Rb, Zr, Nb, TR и Li. Они достигают равновесия при гидростатическом давлении 1-2 килобара, в соответствии с их энизональным окружением. Экспериментально в снстеме гранит-Н $\mathrm{H}_{2} \mathrm{O}-\mathrm{HF}$ алюмофториды образуются в совместных густых парах. Жидкости подобного состава, образуюгцне в результате охлаждения многофазовые включения в волынских пегматитах Украины, содержат криолит и эльпазолит. В результате постмагматического автометасоматизма $\mathrm{F}, \mathrm{Na}$ и другие элементы выделяются и затем переотлагаются, вероятно через жидкости, содержащие сложные ионы, несущие фтор. Кварц-голевошпатовые метасоматиты Восточной Сибири связаны с региональным метаморфизмом и глубинными разломами.

В редких карбонатитах и силикокарбонатитах с высоким содержанием Na фтор концентрировался в поздних гидротермальных растворах с образованием криолита в месторождениях Голди (Колорадо) и Франконский Карьер (Монреаль).

Широко распространенный ральстонит и редкие эльпазолит и веберит кристаллизовались в фумаролах и НF-метасоматизированных основных и средних вулканических лавах. Отложение мине- 


\begin{abstract}
ралов происходило при температуре $300-100^{\circ} \mathrm{C}$. Термальные источники и поверхностные потоки вулханов несут относительно высоко содержание фтора и иногда, в результате их взаимодействия с алюмосиликатным материалом, образуется теархсутит.

Криолит является редким аутигенным минералом осадочных пород формации Грин Пивер на западе СЩА Богатые фтором промежуточные рассолы, образовавшиеся подобно рассолам современного озера Магади в Кении, вероятяо взаимодействовали с вмещающими алюмосилихатными осадочными породами. Геархсутит и креедит, а также пять других недавно открытыг алюмофторидов, встречаются в пределах или под основанием зоны окисления и в коре выветривания некоторых месторождений, богатых фтором. Низкотемпературные осажденные алюмофториды были получены синтетически, но неизвестны в природе.

Единственный алюмофторид, имеющий прахтическое значение, криолит, находился в месторождении, измерявшемся несколькими миллионами тонн, в Ивнгтуте, в южной Гренландия. Там фтор концентрировался непосредственно под плотно изолированной крышей узкой гранитной труьки.
\end{abstract}

Дж. К. Бэйли, Институт петрологии, Остер Вольдгаде 10, ДК-1350, Копенгаген К, Дания.

\section{Introduction}

Cryolite and the cryolite deposit of Ivigtut, $\mathrm{S}$ Greenland, have long been known to geologists through the wide distribution of specimens in mineral collections and the importance of cryolite in the electrolytic refining of aluminium. Quarrying at Ivigtut ceased in 1962 after 106 years of production. Although a number of other cryolite occurrences are known (fig. 1), no other economic deposit has been discovered and the needs of the aluminium industry are now met by the manufacture of synthetic cryolite.

Other aluminofluorides (table 1) have received persistent attention from topographical mineralogists, crystallographers and experimentalists, though their rarity precludes any economic applications. In particular, in the last 20 years, Soviet mineralogists have discovered 5 new aluminofluorides and many localities for this mineral group. The present paper reviews the occurrence and formation of cryolite and the other aluminofluorides largely from a petrologic point of view.

Previous ideas on the genesis of the aluminofluorides mainly centred on the Ivigtut cryolite deposit. Among the many workers who studied the deposit, Baldauf (1910) considered that the cryolite formed by the action of fluoriferous gases upon the original granite magma at Ivigtut. Fersman (1940) relates cryolite formation to the boundary of pneumatolytic and hydrothermal processes in the evolution of alkali granite pegmatites. $F$ and other volatiles may have separated from and then been reintroduced into the rest acid melt. However, Berthelsen \& Noe-Nygaard
(1965) found several features suggesting derivation from peralkaline undersaturated magma. Pauly (1974) compared the roof zone setting of the cryolite deposit with the build up of mineralization connected with other acid igneous activity (e.g. Mo at Climax, Colorado and $\mathrm{Sn}$ in the Erzgebirge).

\section{Cryolite}

\section{(1) Ivigtut, S. Greenland}

The Ivigtut cryolite deposit is located within the roof zone of a pipe-like granite intrusion (fig. 2) (Baldauf 1910; Bøggild 1953; Pauly 19601974 and personal communications 1970-1979; Berthelsen 1962; Berthelsen \& Henriksen 1975; Blaxland 1976; Bailey in preparation). The granite is part of the alkaline Gardar Province of S. Greenland and has been dated at $1248 \pm 25$ m.y. The Gardar period was a time of post-orogenic sedimentation and igneous activity closely related to major faulting.

The Ivigtut granite post-dates a nearby nepheline syenite-carbonatite complex (1327 \pm 17 m.y.) and dyke swarms of olivine dolerite, phonolite and trachyte. Mineralised faults and crush zones (sulphides, carbonates, fluorite), often with high levels of radioactivity, $\mathrm{Sr}, \mathrm{Ba}$ and REE, dissect the surrounding region. Just east of the Ivigtut granite, a breccia with fragments of country rock set in a finer cataclastic matrix was probably emplaced by gas drilling. A radiating set of granophyre dykes, some altered with the addition of cryolite, fluorite, siderite and muscovite (table 2, column 1), centre on the granite and 


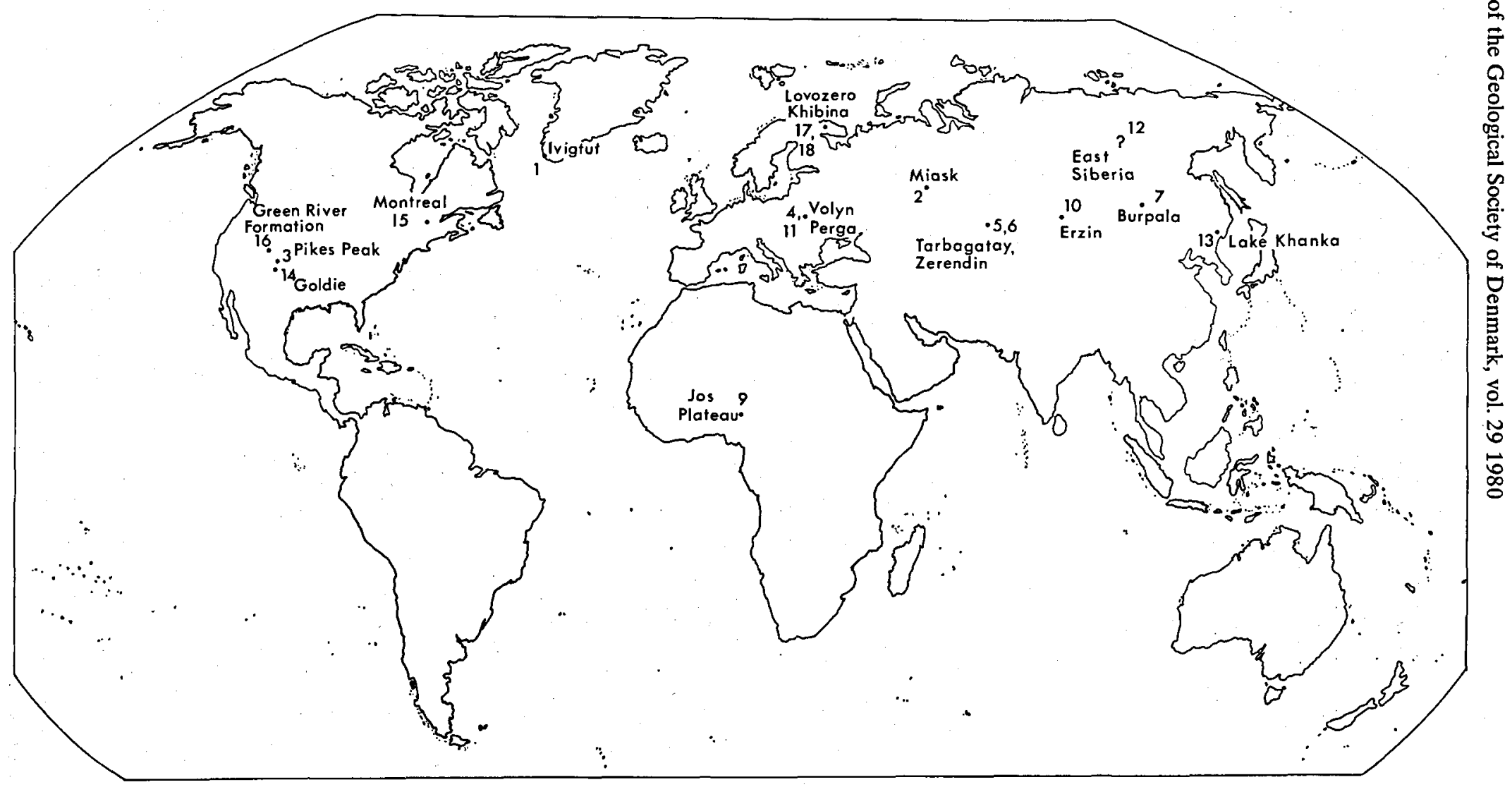

Fig. 1. Location map for confirmed occurrences of cryolite. 
Table 1. List of aluminofluoride minerals.

\begin{tabular}{|c|c|c|c|c|c|c|}
\hline \multirow[t]{2}{*}{ Name } & & \multirow[t]{2}{*}{ Formula } & \multirow[t]{2}{*}{ Symmetry } & \multicolumn{2}{|c|}{ Fluorine wt.\% } & \multirow[t]{2}{*}{ Localities } \\
\hline & & & & ldeal & Observed range & \\
\hline Gyolite & & $\mathrm{Na}_{3} \mathrm{AlF}_{6}$ & $\mathrm{P} \mathbf{1}_{1} / \mathrm{n}$ & 54.30 & $53.35-54.37$ & $1-21$ \\
\hline Cryolithionite & & $\mathrm{Na}_{3} \mathrm{Li}_{3}\left(\mathrm{~A} \mid \mathrm{F}_{6}\right)_{2}$ & la3d & 61.33 & 60.79 & 1,2 \\
\hline Elpasolite & & $\mathrm{K}_{2} \mathrm{~N}_{0 A I F}$ & Po3 & 47.07 & $46.98-47.90$ & $3,4,11,14,22$ \\
\hline Pachnolite & & $\mathrm{NaCaAIF}_{6} \cdot \mathrm{H}_{2} \mathrm{O}$ & $\mathrm{C} 2 / \mathrm{c}$ & 51.33 & $50.51-51.94$ & $1-3,11,12,14,23,24$ \\
\hline Thomsenolite & & $\mathrm{NaCaAlF}_{6} \cdot \mathrm{H}_{2} \mathrm{O}$ & $\mathrm{P}_{\mathrm{J}} / \mathrm{c}$ & 51.33 & $48.60-50.65$ & $1-3,5,7,9-12,21,23$ \\
\hline Corlhintzeite & & $\mathrm{Ca}_{2} \mathrm{AlF}_{7} \cdot \mathrm{H}_{2} \mathrm{O}$ & Triclinic & 51.52 & 52.1 & 24 \\
\hline Jorlite & & $\mathrm{NoS}_{2} \mathrm{Al}_{2}(\mathrm{~F}, \mathrm{OH})_{11}$ & $\mathrm{c} / \mathrm{m}$ & 45.32 & $43.23-45.50$ & 1 \\
\hline Chiolite & & $\mathrm{Na}_{5} \mathrm{Al}_{3} \mathrm{~F}_{14}$ & $\mathrm{P} 4 / \mathrm{mnc}$ & 57.59 & $57.30-57.81$ & $1,2,11$ \\
\hline Weberite & & $\mathrm{Na}_{2} \mathrm{MgAlF}_{7}$ & Imma & 57.76 & $53.05-57.58$ & $1,3,5,11,12,14,21,35$ \\
\hline Ralstonite & & $\mathrm{Na}_{x} \mathrm{Mg}_{x} \mathrm{Al}_{2-x}(\mathrm{~F}, \mathrm{OH})_{6} \cdot \mathrm{H}_{2} \mathrm{O}$ & $\mathrm{Fd} 3 \mathrm{~m}^{21}$ & 55 & $39.36-57.70$ & $1-3,7,11,12,14,21,23,25-36$ \\
\hline Prosopite & & $\mathrm{CaAl}_{2}(\mathrm{~F}, \mathrm{OH})_{8}$ & $\mathrm{C} 2 / \mathrm{c}$ & 31.92 & $29.55-35.01$ & $\mathrm{I}-3,11,14,37-39$ \\
\hline Gearksutite & & $\mathrm{CaAl}(\mathrm{F}, \mathrm{OH})_{5} \cdot \mathrm{H}_{2} \mathrm{O}$ & Monoclinic & 42.68 & $35.00-42.68$ & $1-3,5,7,10,11,14,23,27,40-56$ \\
\hline Tikhonenkovite & & $(\mathrm{Sr}, \mathrm{Ca}) \mathrm{AlF}{ }_{4} \mathrm{OH} . \mathrm{H}_{2} \mathrm{O}$ & $\mathrm{P}_{1} / \mathrm{c}$ & 37.65 & 33.88 & 54 \\
\hline Yaroslavite & & $\mathrm{Ca}_{3} \mathrm{Al}_{2} \mathrm{~F}_{10}(\mathrm{OH})_{2} \cdot \mathrm{H}_{2} \mathrm{O}$ & Orthorhombic & 45.65 & 46.90 & 57 \\
\hline Usovite & & $\mathrm{Bo}_{2} \mathrm{CaMgAl}_{2} \mathrm{~F}_{12}$ & Monoclinic & 39.24 & 39.80 & 58 \\
\hline Calcjarlite. & & $\mathrm{NaCa}_{3} \mathrm{Al}_{3}(\mathrm{OH})_{2} \mathrm{~F}_{14}$ & - & 50.75 & 47.50 & 58 \\
\hline Creedite & & $\mathrm{Ca}_{3} \mathrm{Al}_{2} \mathrm{~F}_{8}(\mathrm{OH})_{2} \mathrm{SO}_{4} \cdot 2 \mathrm{H}_{2} \mathrm{O}$ & $\mathrm{C} 2 / \mathrm{c}$ & 30.90 & $27.00-30.70$ & $5,27,40,48,52,53,59-71$ \\
\hline Chukhrovite & & $\mathrm{Ca}_{3} \mathrm{Al}{ }_{2}(\mathrm{Y}, \mathrm{Ce}) \mathrm{F}_{13} \mathrm{SO}_{4} \cdot 10 \mathrm{H}_{2} \mathrm{O}$ & Cubic & 29.5 & $27.88-28.32$ & $48,57,69$ \\
\hline Beggildite & & $\mathrm{Na}_{2} \mathrm{Sr}_{2} \mathrm{Al}_{2}\left(\mathrm{PO}_{4}\right) \mathrm{F}_{9}$ & Monoclinic & 31.60 & 31.70 & 1 \\
\hline Stenonite & & $\mathrm{Sr}_{2} \mathrm{AICO}_{3} \mathrm{~F}_{5}$ & Monoclinic & 26.59 & 25.84 & 1 \\
\hline
\end{tabular}

1. See Pauly (1965, p. 1862).

Notes: Fluellite, long listed with the aluminofluorides, is a phosphate, $\mathrm{Al}_{2}(\mathrm{~F}, \mathrm{OH})_{3} \mathrm{PO}_{4} \cdot 7 \mathrm{H}_{2} \mathrm{O}$ (Guy \& Jeffrey 1966).

Boldyrevite, occasionally listed as an independent aluminofluoride, is more likely a variety of ralstonite (Stepanov \& Sokolova 1963).

Localities: 1 Ivigtut, Greenland; 2 Miask, Urals; 3 Pikes Peak, Colorado; 4 Volyn, Ukraine; 5 Torbagatay, Kazakhston; 6 Zerendin, Kazakhstan; 7 Burpala, Transbaikal; 8 Lesser Chingo, Manchuria (?); 9 Jos Plateau, Nigeria; 10 Erzin massif, Tuva; 11 Perga,Ukraine; 12 E. Siberia; 13 Lake Khanka, Maritime Province, U.S.S.R.; 14 Goldie deposit, Colorado; 15 Francon quarry, Montreal; 16 Green River Formation, W U.S.A.; 17 Lovozero massif, Kola, U.S.S.R.; 18 Khibino massif, Kola, U.S.S.R.; 19 Yellowstone Park, W U.S.A. (?); 20 Earth, soil (?); 21 Tristan da Cunha, S. Atlantic (?); 22 Nyiragongo, Zolre; 23 Gjerdingen, S. Norway; 24 Hagendorf-Süd, Bavaria; 25 Vesuvius, Italy; 26 Kamehatka, U.S.S.R.; 27 Upper Kayraktin, Kazakhstan; 28 5. Priseo, Italy; 29 Pacaya, Guatemala; 30 Santiaguito, Guatemala; 31 Izalco, El Salvador; 32 Cerro Negro, Nicaragua; 33 Arenal, Costa Rica; 34 El Misti, Peru; 35 Deception Is., South Shetlands; 36 Kilavea, Hawaii; 37 Altenberg, Saxony; 38 Dugway, Utah; 39 Santa Rosa, Mexico; 40 Wagon Wheel Gop, Colorado; 41 Gingin, W. Australia; 42 Hot Springs, Virginia; 43 Vulcano, Italy; 44 Belukho, Iransbaikal; 45 Bukuka, Transbaikal; 46 Marysvale, Utah; 47 Northern Kounrad, Kazakhstan; 48 Karaoba, Kazakhstan; 49 Kalanguy, Transbaikal; 50 Etika, Iransbaikal; 51 Dzhida, Transbaikal; 52 Akmaya, Kazakhstan; 53 Batistay, Kazokhstan; 54 Karasug, Tuva; 55 Manzhinsk, U.S.S.R.; 56 Sor, U.S.S.R.; 57 Siberia; 58 Upper Noiby River, Siberia; 59 Granite, Nevada; 60 Colquiri, Bolivia; 61 Darwin, California; 62 Akchatoy, Kazakhstan; 63 Eastern Kounrad, Kazakhstan; 64 Boinazar, Kazakhstan; 65 Nura-Taldy, Kazakhstan; 66 Selitei, Kazakhston; 67 Shelitovoye, Kazakhstan; 68 Western, Kazakhstan; 69 Dzhaamba, E. Pamir, U.S.S.R.; 70 Santo Eulalia, Mexico; 71 Bergheim, France. (?) unconfirmed localities. 
immediately preceded its emplacement. The granite pipe - only $270 \mathrm{~m}$ in diameter - penetrated a slightly older intrusion breccia, up to $60 \mathrm{~m}$ wide. Its chilled porphyritic microgranite roof arcs over the cryolite deposit and probably acted as a capping to F-rich fluids which became concentrated in the top of the narrow pipe.

The Ivigtut granite has suffered extensive post-magmatic autometasomatism (table 2 , columns 2-4). Approaching the cryolite deposit, fresh roof zone granite passes into hydrothermally altered and leached variants, locally albitised granite and then extensive greisens. Beneath the cryolite deposit, the intensity of greisenization diminishes down to $550 \mathrm{~m}$ depth (the deepest drilling) but the same sequence of autometasomatism can be discerned in virtually every sample.

The fresh granite is a hornblende biotite leucogranite with alkalic affinities. Accessories include fayalite, zircon, magnetite, ilmenite, apatite, fluorite and siderite. Hydrothermally altered granites show sericitised and partly exsolved perthites, and increased biotite, muscovite and quartz contents. In albitised granites, albite ranges from $45-65$ vol. $\%$ and replaces quartz and potash feldspar. Some albitised granites contain abundant late cryolite. During greisenization, the only feldspar is relict microcline; muscovite and quartz contents increase and there is a significant development of mineralised greisens with siderite, fluorite, cryolite, topaz, sulphides, zircon, columbite and cassiterite. Greisens with up to $30 \%$ cryolite extend for tens of metres.

The granite beneath the cryolite deposit is a two-feldspar metasomatised leucogranite. Leaching plus feldspar exsolution, albitization, greisenization and microfracturing occurred in that order. Levels of $\mathrm{Zr}, \mathrm{Nb}, \mathrm{Ta}, \mathrm{Th}, \mathrm{U}, \mathrm{REE}$ and $\mathrm{F}$ are notably high (table 2 , column 5 ).

A large pegmatite sill, up to $9 \mathrm{~m}$ thick, lay above the cryolite deposit and crystallised before the metasomatic activity. It contained a vugh, 1.5-2 $\mathrm{m}$ across, with quartz, siderite, fluorite, muscovite, weberite, cryolite, zircon, columbite, arsenopyrite, molybdenite and other sulphides.

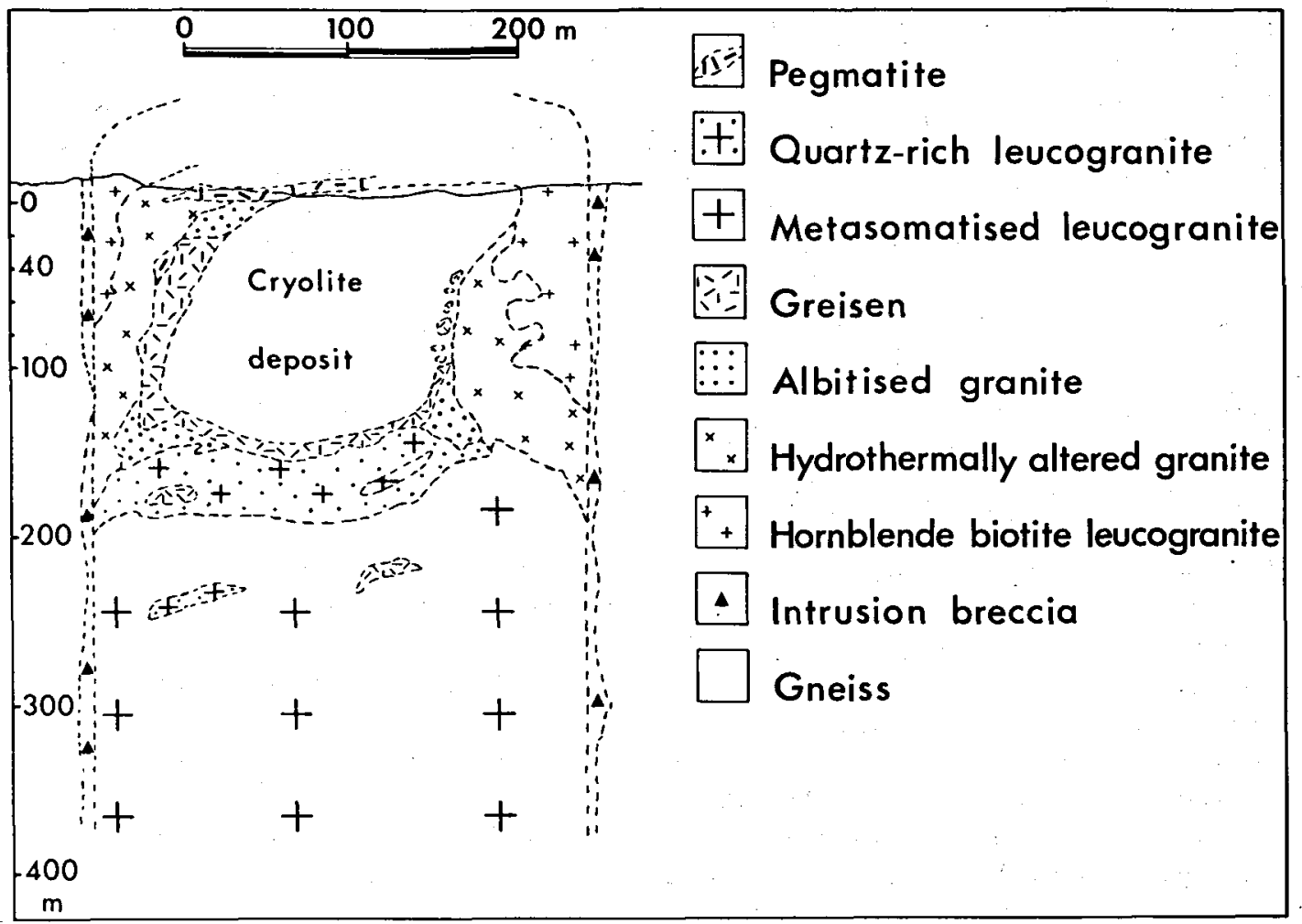

Fig. 2. Geological section through Ivigtut granite and cryolite deposit, S. Greenland (Bailey, in preparation). 
The same minerals, formed interstitially at a late stage, are also scattered through the pegmatite. Lenses and patches of pegmatite also developed in the diffuse granite-greisen contact zone. They exhibit albitization, greisenization and late patches of cryolite, quartz and sulphides. Quartz veins containing cassiterite, sulphides, cryolite and siderite cut the Ivigtut granite, greisen and surrounding gneisses.

The cryolite deposit itself, about $12.10^{6}$ tons, is volumetrically much more important than these earlier pegmatites, and its margins are not defined by any extensive silicate pegmatite material. The upper (mined) part of the body consists of siderite-cryolite with a few percent of sulphides, fluorite and quartz. Locally it contained radioactive, Th-Sr-REE-rich reddish brown fluorite associated with black cryolite. A large mass and occasional veins of pure cryolite also occurred in the siderite-cryolite. Around the western part of the siderite-cryolite is a shell of cryolite containing fluorite, topaz, muscovite, weberite, jarlite and other aluminofluorides. Underlying this is a shell of fluorite with topaz, muscovite and quartz. Beneath the eastern part of the siderite-cryolite is a siderite-quartz shell. Beneath these shells is an extensive unit consisting of quartz with minor amounts of siderite, muscovite and sulphides. Brecciation characterises the borders between the shells and also the contact with the enveloping rocks.

Of the other aluminofluorides, coarsely crystalline masses of chiolite occur in the fluoritecryolite shell at the border with pure cryolite. Weberite occurs as mentioned in a vugh of the pegmatite sill, and is commonly up to a few $\%$ in the fluorite-cryolite. Jarlite occurs in cavities within late barite-rich columnar aggregates in the fluorite-cryolite shell and as inclusions in chiolite. Cryolithionite occurs as dodecahedral crystals up to $17 \mathrm{~cm}$ across and enclosed by coarse grained, pure cryolite. Fissures and cavities within cryolite are filled by secondary phases, roughly in the sequence: thomsenolite, pachnolite, prosopite, ralstonite, fluorite and gearksutite. Secondary cryolite also occurs on such fissures.

The commonest sulphide of the cryolite deposit is sphalerite which is associated with chalcopyrite and galena. The ubiquitous association of these sulphides with siderite lead Karup-Møller \& Pauly (in press) to suggest that immiscible Fe-rich carbonate-sulphide drops were distributed evenly throughout the original fluid body. Sulphides form about $2 \%$ of the siderite-cryolite shell, mainly sphalerite, galena, chalcopyrite and pyrite. The galena is rich in $\mathrm{Ag}$ and $\mathrm{Bi}$ and contains small amounts of various sulphides (Pauly 1960). A pocket of rare $\mathrm{Bi}-\mathrm{Ag}-\mathrm{Pb}-\mathrm{Cu}$ sulphides may have formed when late fluorite-rich material brecciated and mobilised galena-disseminated material from the adjacent siderite-rich shell (Karup-Møller 1973).

Based on quartz morphology and the sphalerite geothermometer, Pauly (1960) estimated maximum temperatures of $510-590^{\circ} \mathrm{C}$ for the siderite-cryolite. Temperatures of $200-300^{\circ} \mathrm{C}$ have been suggested for the fluorite shell (Karup-Møller 1973).

On geological, geochemical and isotopic grounds, the Ivigtut granite can be regarded as a residual acid magma which has ultimately fractionated from mantle-derived basaltic material. However, both $\mathrm{Sr}$ and $\mathrm{Pb}$ isotopic studies (Ulrych 1964; Blaxland 1976) indicate that crustal materials contributed to the formation of cryolite and galena from the metasomatised granites and the cryolite deposit.

\section{(2) Miask, Ilmen Mts., Chelyabinsk district, USSR}

In the southern Urals, megacrystalline cryolite and cryolithionite filled a $1.1 \mathrm{~m}$ drusy cavity in a lens-like vein of granite pegmatite. The locality is sometimes referred to as the cryolite mine or the topaz-cryolite quarry of Gasberg. The quarry was opened about 1840 and the cryolite noted in 1845; excavations have long ceased and the dumps also removed (von Kokscharov 1862; Zavaritsky 1939; Afanas'yev 1949; Stepanov \& Moleva 1962; Stepanov 1963).

According to the general description of the.IImen State Mineralogical Reservation (Zavaritsky \& Kryjanovsky 1937), cross-cutting granitic pegmatites are abundant in the zone of the Variscan granite gneisses. Most are composed of microcline perthite, quartz and mica. Beryl, topaz, tourmaline and phenacite are mainly confined to albitised portions and miarolitic vughs. Aluminofluorides only occur in the single pegmatite.

The cryolite-bearing pegmatite is located among amphibolites and granite gneisses dipping 
$\mathrm{SE}$ at $35^{\circ}$. The pegmatite vein, however, dips $60^{\circ} \mathrm{N}$ and follows a joint system in the metamorphic rocks. It is up to $4 \mathrm{~m}$ thick. The margins are composed of coarsely crystalline granite; then comes a graphic granite zone and finally a core of pegmatitic granite composed of albitised feldspar and amazonite, smoky quartz, and black and white micas. In sheet-like parts of the vein, fine-grained white feldspar and garnet predominate. The pegmatite also contained aquamarine, topaz, columbite, phenacite and the aluminofluorides.

The cryolite was located in a nest up to $1.1 \mathrm{~m}$ in diameter which was separated from the rest of the pegmatite by a margin of quartz, cryolite and white mica. The nest lay in albitised granite. Approaching it the abundance of topaz fell rapidly.

Intergrowths of cryolite with cryolithionite (up to. $15-20 \mathrm{~cm}$ in diameter) are reminiscent of graphic texture. The cryolite, notably at the contact with the pegmatite, was replaced by chiolite, green fluorite and second generation cryolithionite. All these phases were replaced by veinlets and aggregates of pachnolite, thomsenolite intergrown with ralstonite, and prosopite. Earthy gearksutite filled voids in prosopite and, at the supergene stage, developed together with halloysite.:

(3) St. Peters Dome pegmatite area, Pikes Peak-Mount Rosa, Colorado

Cryolite and other aluminofluorides occur in three alkali granite pegmatites at the Eureka tunnel and Cryolite mine, St. Peters Dome district, Colorado (Cross \& Hillebrand 1883 1885; Landes 1935; Frondel 1948; Pauly 1954; Gross \& Heinrich 1966). Cryolite masses were also found in several small quartz-microcline veins north and west of St. Peters Dome (Cross \& Hillebrand 1885 , p. 41 ).

The pegmatites and their parent Mount Rosa riebeckite granite are the final intrusions of the southern part of the Pikes Peak batholith (table 2, column 7) (Gross \& Heinrich 1965; Barker et al. 1975). The batholith is 1040 m.y. in age, anorogenic, intruded at shallow level, composite and generally subalkalic. Biotite granite and biotite-hornblende granite are dominant; a more sodic differentiation trend including quartz syenite, fayalite and the Mount Rosa riebeckite granite is present in minor amounts. In this sodic series, average $\mathrm{F}$ contents increase from $0.30 \%$ in quartz syenite to $0.63 \%$ in the Mount Rosa granite and presumably reach even higher values in the derivative pegmatites. The Mount Rosa granite forms a small irregular sheet less than $50 \mathrm{~m}$ thick. Its mineralogy and textural variations are quite complex; there are considerable pegmatitic areas. The major minerals are microcline perth-. ite, quartz, albite-oligoclase, riebeckite and astrophyllite. $\mathrm{F}$ is carried by riebeckite, astrophyllite, biotite, muscovite, fluorite and pyrochlore; careful search by Gross \& Heinrich (1965) failed to reveal cryolite and thomsenolite as in the Nigerian riebeckite granites.

Pegmatites from the biotite granites are characterised by quartz and amazonite crystals, zircon, biotite, siderite, and minor topaz, allanite, cassiterite and genthelvite. The younger Mount Rosa quartz-microcline-riebeckite pegmatites contain radioactive zircon, fluorite, astrophyllite, thorite and lesser pyrochlore, rutile, $\mathrm{Nb}$ rutile, columbite, bertrandite and aluminofluorides. The latter include cryolite, pachnolite, elpasolite, ralstonite, thomsenolite, prosopite, weberite and gearksutite. Masses of aluminofluorides up to $2 \mathrm{~m}$ across were found on the walls of the Eureka tunnel. Cryolite apparently occurred as fracture fillings in the original quartz-microcline-zircon pegmatite. It alters to the other aluminofluorides. Elpasolite lines solution cavities in massive pachnolite (Frondel 1948).

The aluminofluorides have been assigned to the hydrothermal replacement stage of the pegmatites along with albite, astrophyllite, fluorite, sulphides, thorite and bertrandite (Gross \& Heinrich 1966). The complex pegmatites which contain the aluminofluorides occur in the pegmatite zone furthest away from the Mount Rosa granite. Elements diagnostic of these pegmatites include $\mathrm{Zr}, \mathrm{Th}, \mathrm{Ti}, \mathrm{Nb}, \mathrm{Ta}, \mathrm{Ce}$ and $\mathrm{Y}$.

(4) Volyn chamber pegmatites, N.W. Ukraine In the Volyn (Volhynia) granite chamber pegmatites of the Ukraine (fig. 3), cryolite occurs in multi-phase fluid inclusions and as solid inclusions, in topaz and quartz.

The Volyn pegmatites lie in the southwestern part of the Korostensky igneous complex which was formed at the platform stage of the Ukrainian basement about 1900-1600 m.y. ago. The complex consists of hornblende-biotite rapakivi 
Table 2. Chemical composition of granites and other materials related to cryolite occurrences.

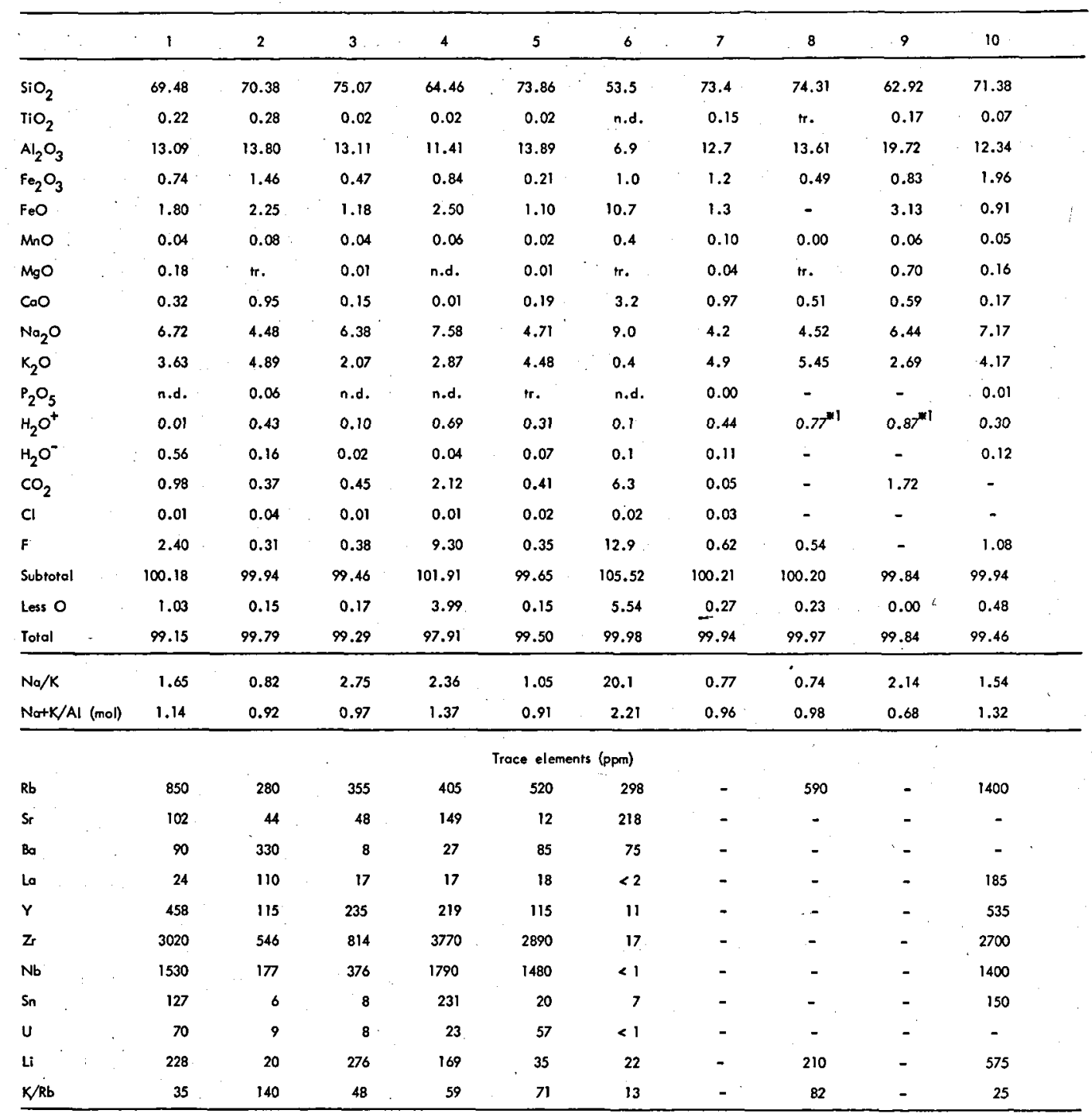

- not determined, n.d. not detected, $\pi$. trace, 1 loss on ignition

1 Cryolite-beoring metasomatised granophyre dyke, Ivigtut, S. Greenland, sample 1029/ER/60 (Bailey, in preparation).

2 Hornblende biotite leucogranite, Ivigtut, S. Greenland, ov. of 8 analyses (Bailey, in preparation).

3 Albitised granite, Ivigtut, S. Greenland, sample $J 4136.18$ (Bailey, in preparation).

4 Cryolitised greisen, Ivigtut, S. Greenland, sample 20158.4 (Bailey, in preparation).

5 Metasomatised leucogranite beneath cryolite deposit, Ivigtut, 5. Greenland, ov, of 16 analyses (Bailey, in preparation).

6 Cryolite deposit, Ivigtut, 5. Greenland (Bailey, in preparation). Total includes $1.0 \% 5$.

7 Mount Rosa riebeckite granite, Colorodo (Borker et al. 1976, Table 1, sample S7I-MI).

8 Orthoclase-perthite-quartz-albite-zinnwaldite graphic pegmatite from Pisarevskaya Guta, Volyn, Ukraine (Gavrusevich 1932). F, traces and K/Rb on a different Volynia pegmatite (Stavrov \& Bykova 1961).

9 Albitised pegmatite, Volyn, Ukraine (Kalyuzhny et al. 1973, analysis 3).

10 Albitised riebeckite granite, Kaffo valley, Liruei complex, Nigerio (Bowden \& Turner 1974, Table 3, column 3 and Table 4). Sample also contains $0.05 \%$ S, 55 ppm Go, 75 ppm Yb. 
Table 2 (continued).

\begin{tabular}{|c|c|c|c|c|c|c|c|c|c|c|}
\hline & 11 & 12 & 13 & 14 & 15 & 16 & 17 & 18 & 19 & 20 \\
\hline $\mathrm{SiO}_{2}$ & 73.39 & 73.97 & 72.28 & 68.90 & 73.86 & 13.74 & $\sim 1$ & 45.5 & 27 & 73.44 \\
\hline $\mathrm{IiO}_{2}$ & 0.22 & 0.18 & 0.27 & 0.17 & 0.20 & - & - & 0.27 & 0.34 & 0.22 \\
\hline $\mathrm{Al}_{2} \mathrm{O}_{3}$ & 13.18 & 11.75 & 11.37 & 11.18 & 13.75 & 10.23 & $\sim 10$ & 19.7 & 6.6 & 13.61 \\
\hline $\mathrm{Fe}_{2} \mathrm{O}_{3}$ & 1.40 & 0.81 & 1.82 & 2.34 & 0.78 & 0.25 & 0.09 & 0.2 & 2.9 & 0.92 \\
\hline $\mathrm{FeO}$ & 1.43 & 1.53 & 2.06 & 3.19 & 1.13 & 0.21 & - & 2.0 & - & 1.38 \\
\hline $\mathrm{MnO}$ & 0.04 & 0.01 & 0.09 & 0.08 & 0.05 & - & - & 0.25 & 0.03 & 0.08 \\
\hline $\mathrm{MgO}$ & 0.05 & 0.45 & 0.10 & 0.10 & 0.26 & 0.75 & $\sim 12$ & 0.8 & 2.8 & 0.47 \\
\hline $\mathrm{CaO}$ & 1.26 & 0.95 & 0.76 & 0.10 & 0.72 & 51.74 & 9.3 & 2.5 & 6.7 & 1.30 \\
\hline $\mathrm{Na}_{2} \mathrm{O}$ & 3.52 & 4.50 & 4.58 & 6.44 & 3.51 & 0.13 & $\sim 8$ & 8.6 & 2.4 & 3.13 \\
\hline $\mathrm{K}_{2} \mathrm{O}$ & 4.84 & 4.25 & 4.93 & 4.23 & 5.13 & 0.82 & 0.7 & 4.2 & 1.1 & 4.76 \\
\hline $\mathrm{P}_{2} \mathrm{O}_{5}$ & - & 0.00 & 0.02 & 0.02 & 0.14 & - & $<1$ & 0.12 & 0.3 & 0.12 \\
\hline $\mathrm{H}_{2} \mathrm{O}^{+}$ & 0.22 & 0.14 & $0.35^{* 1}$ & $0.44^{* 1}$ & 0.47 & 0.84 & - & 3.5 & $42.3^{* 1}$ & 0.42 \\
\hline $\mathrm{H}_{2} \mathrm{O}^{-}$ & 0.13 & $1.12^{* 1}$ & n.d. & 0.80 & - & - & - & - & - & 0.16 \\
\hline $\mathrm{CO}_{2}$ & - & - & 0.10 & 0.03 & - & 0.21 & - & 11.0 & - & - \\
\hline $\mathrm{Cl}$ & - & - & - & - & - & - & - & 0.03 & - & - \\
\hline$F$ & 0.44 & 0.82 & 0.56 & 2.57 & - & 35.24 & 49.7 & 0.31 & 0.1 & - \\
\hline Subtotal & 100.12 & 100.48 & 99.29 & 100.59 & 100.00 & 114.16 & & 98.98 & & 99.99 \\
\hline Less 0 & 0.16 & 0.34 & 0.24 & 1.10 & 0.00 & 15.14 & & 0.14 & & $0 . \infty 0$ \\
\hline Total & 99.96 & 100.14 & 99.05 & 99.49 & 100.00 & 99.02 & & 98.84 & & 99.99 \\
\hline $\mathrm{No} / \mathrm{K}$ & 0.65 & 0.95 & 0.83 & 1.36 & 0.61 & 0.14 & $\sim 10$ & 1.83 & 1.95 & 0.59 \\
\hline $\mathrm{Na}+\mathrm{K} / \mathrm{Al}$ (mol) & 0.84 & 1.02 & 1.13 & 1.36 & 0.82 & 0.11 & $\sim 1.4$ & 0.95 & 0.78 & 0.76 \\
\hline \multicolumn{11}{|c|}{ Trace elements (ppm) } \\
\hline $\mathrm{Rb}$ & - & - & 680 & 690 & - & - & - & - & - & - \\
\hline Sc & - & - & - & - & - & - & 2000 & 400 & 245 & - \\
\hline Ba & - & - & - & - & - & - & 5000 & 1600 & 300 & - \\
\hline La & - & - & - & - & - & - & - & - & - & - \\
\hline Y & - & - & - & - & - & - & - & - & - & - . \\
\hline z & - & - & 1700 & 2100 & - & - & - & 440 & 60 & - \\
\hline Nb & - & - & - & - & - & - & - & 840 & - & - \\
\hline$S_{n}$ & - & - & - & - & - & - & - & - & - & - \\
\hline$u$ & - & - & - & - & - & - & - & - & 5.19 & - \\
\hline $1 i$ & - & - & 90 & 280 & - & 200 & - & - & 43 & - \\
\hline $\mathrm{K} / \mathrm{kb}$ & - & - & 60 & 51 & - & - & - & - & - & - \\
\hline
\end{tabular}

- not determined, n.d. not detected, I loss on ignition

11 Biotite microcline opogranite, Large massif, N.W. Tarbagatoy, Kazakhstan (Mineev 1968, Table 4, column 4 ).

12 Pergo gronite, N.W. Ukraine, somple P-17 (Zinchenko 1968). Tot ol includes $0.05 \% \mathrm{SO}_{3}$.

13 Riebeckite opogranite gneiss, E. Siberio (Kudrin 1972, Table 1, column 5).

14 Amphibole opogneissic-schist, E. Siberio (Kudrin 1972, Table 1, column 9).

is Average alkali granite (Nockolds 1954).

16 Fluorite-mica ore containing cryolite, Lake Khanka, U.S.S.R. (Rub 1960, Tabie 46, column I). Includes $0.2 \% \mathrm{~B}_{2} \mathrm{O}_{3}$.

17 Aluminofluoride nodule in Goldie corbonatite, Colorado (Heinrich 1977, Table 3).

18 Dawsonite-bearing silico-carbonatite sill, Monireal Island, Quebec (Jambor et ol. 1976, Table 63.1, F-9).

19 Rich oil shale, Mahogony bed, Green River Formation, W. USA (Desborough et al. 1976, Table IV, sample C154). Includes total 5 1.75\%,

B 60 ppm, $\vee 150$ ppm, As 35 ppm, Th 7.19 ppm.

20 Average tin gronile (Klominsky \& Groves 1970). 


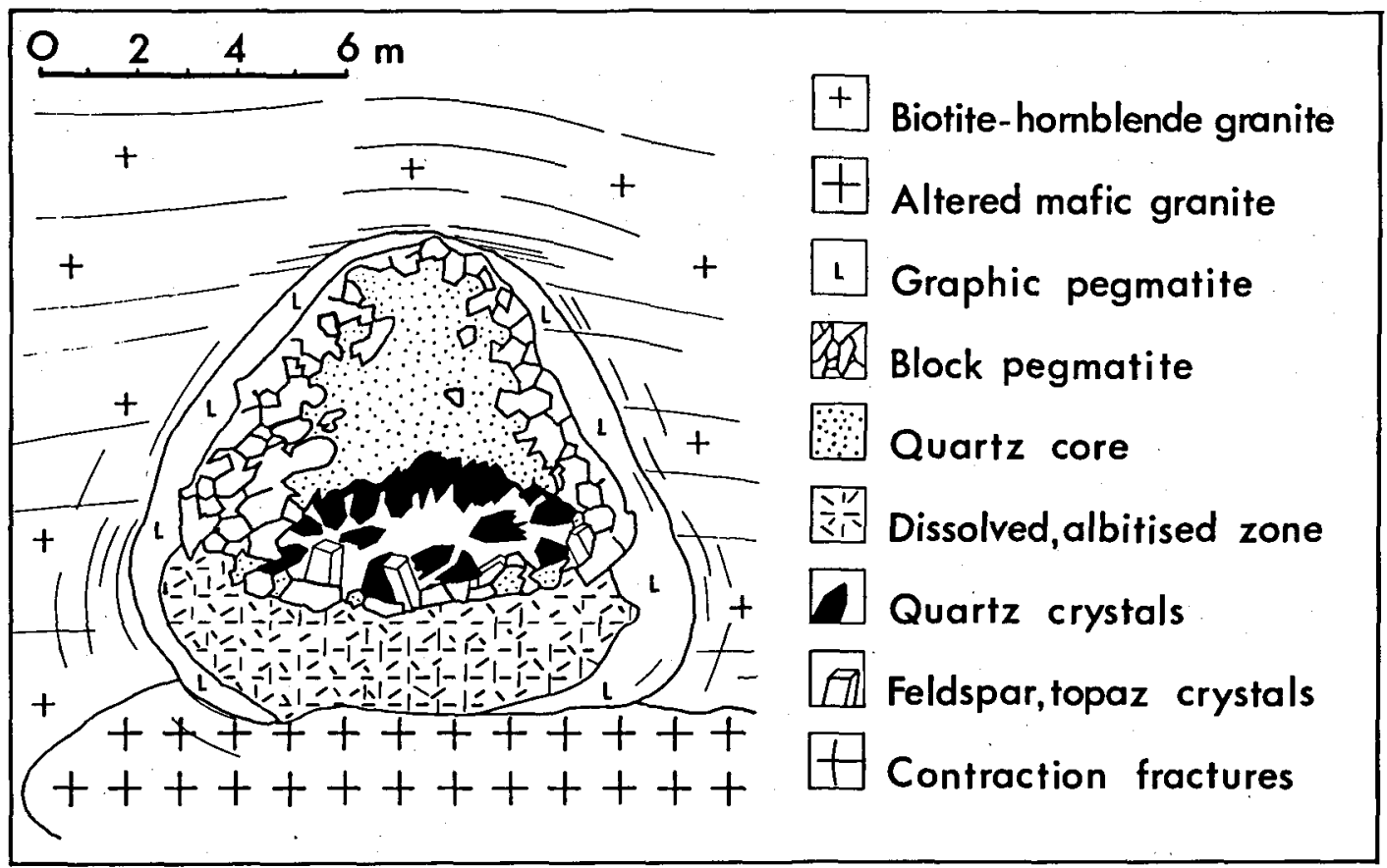

Fig. 3. Schematic geological section through a Volyn chamber pegmatite, Ukraine (after Zakharchenko 1971).

granites and associated gabbros, anorthosites and alkali granites and was associated with a major period of faulting. Characteristic accessories for the rapakivi granites are zircon, fluorite, topaz, apatite, allanite and titanomagnetite. Chemically, they exhibit high $\mathrm{Fe} / \mathrm{Mg}$ ratios and high contents of alkalis, Sn, Mo, REE and F (0.13-0.2\%) (Ivantishin et al. 1964; Galetskii \& Zinchenko 1972; Tolstoy et al. 1973).

The pegmatites are confined to the margins of the rapakivi granites next to the gabbroic rocks, in an area which is $100-1000 \mathrm{~m}$ wide and about $20 \mathrm{~km}$ long. Near this contact, rising volatiles were preferentially concentrated in granites free from gabbro contamination. Prolonged cooling of roof-zone granites above a deep granite magma root and below the unconsolidated gabbros lead to enhanced magma-volatile separation. This was also encouraged by formation of a rigid roof which held back the pressure of the overlying rocks and created a low-pressure focus for rising volatiles. As the crystallization front of the granite magma slowly descended segregation of pegmatite magma periodically repeated itself (Kalyuzhny \& Gigashvili 1972). The grain size of the host granite, and the contents of $F$, fluorite and biotite all increase gradually into the pegmatites indicating closed-system crystallization (Stavrov \& Bykova 1961; Muzhanovsky et al. 1970). However, in the late stages of the pegmatites the system became open as a result of contractional fracturing (table 3 ). The pegmatites may contain cavities up to 400 cubic metres. in volume and are mined for quartz, fluorite and gemstones.

A great variety of fluid inclusions have been described in remarkable detail from the pegmatites. I have attempted to place them in a simplified evolutionary sequence: silicate-rich inclusions, dense saline brines, and dilute hydrothermal solutions (Bailey 1977). Increase in $\mathrm{H}_{2} \mathrm{O}, \mathrm{CO}_{2}$ and carbonates, $\mathrm{H}_{2} \mathrm{~S}$ and sulphates, $\mathrm{H}_{2} \mathrm{O} / \mathrm{Cl}, \mathrm{Cl} / \mathrm{F}, \mathrm{Ca}^{2+}$ and $\mathrm{Fe}^{3+} / \mathrm{Fe}^{2+}$ can be discerned in the evolution, which appears to exhibit a continuous gradation from granite melt to dilute hydrothermal solutions. A similar scheme is offered by Zakharchenko (1971) (table 3).

Kalyuzhnaya et al. (1973) emphasised that the Volyn pegmatites undergo variable metasomatism during the later stages. They distinguish albitised pegmatites with a predominance of $\mathrm{Na}_{2} \mathrm{O}(5.05-6.46 \%), \mathrm{Li}, \mathrm{Be}, \mathrm{Zr}, \mathrm{Y}, \mathrm{Nb}$, 
Table 3. Development stages of the Volyn cavity pegmatites, Ukraine (after Zakharchenko 1971, Kalyuzhny \& Gigashvili 1972).

\begin{tabular}{|c|c|c|c|c|c|}
\hline Stage & $\mathrm{T}^{\circ} \mathrm{C}$ & $\mathrm{pH}$ & Inclusions & Main processes & Moin minerals \\
\hline \multicolumn{6}{|c|}{ PRE-QUARTZ INVERSION } \\
\hline $\begin{array}{l}\text { Formation of } \\
\text { pegmatite zones }\end{array}$ & $700-600$ & $\begin{array}{l}9.5 \\
10 \\
6.8\end{array}$ & $\begin{array}{l}M+G+D M \\
\text { hom } \rightarrow M \\
G+L+D M+M \\
\text { hom } \rightarrow V M M\end{array}$ & $\begin{array}{l}\text { Development of zones: } \\
\text { graphic, pegmatoid, } \\
\text { feldspar, blocky quartz }\end{array}$ & $\begin{array}{l}\text { Graphic and blocky quartz, } \\
\text { orthoclase, intermediate K-feldspar }\end{array}$ \\
\hline Chamber formation & & & & $\begin{array}{l}\text { Chamber formation, } \\
\text { contraction, albitization }\end{array}$ & $\begin{array}{l}\text { "Honeycomb" quartz, microcline, } \\
\text { albite } 1\end{array}$ \\
\hline \multicolumn{6}{|c|}{ POST-QUARTZ INVERSION } \\
\hline Acid I & $600-<00$ & $5.0-6.0$ & $\begin{array}{l}G+L+D M \\
\text { hom } \rightarrow G\end{array}$ & $\begin{array}{l}\text { Continued albitization, } \\
\text { opening of pegmatites }\end{array}$ & $\begin{array}{l}\text { Ice-like quartz, albite I, } \\
\text { topaz }\end{array}$ \\
\hline Alkaline I & $>500-400$ & $7.5-9.2$ & $\begin{array}{l}G+L+D M \\
\text { hom } \rightarrow S G\end{array}$ & $\begin{array}{l}\text { Early microclinization, } \\
\text { end of cavity formation } \\
\text { leaching, recrystallization }\end{array}$ & $\begin{array}{l}\text { Smoky quartz and morion, } \\
\text { microcline I }\end{array}$ \\
\hline Acid II & $500-300$ & $6.5-4.2$ & $\begin{array}{l}\text { G+L+DM } \\
\text { hom } \rightarrow L\end{array}$ & $\begin{array}{l}\text { Albitization, fluorine } \\
\text { metasomatism, quartzifi- } \\
\text { cation, kaolinization }\end{array}$ & $\begin{array}{l}\text { Spotty quartz, cleovelondite, } \\
\text { topaz, phenacite, beryl, fluorite, } \\
\text { protolithionite, columbite, cryolite, } \\
\text { tourmaline, molybdenite, siderite }\end{array}$ \\
\hline Alkaline II & $350-250$ & $7.0-8.0$ & $\begin{array}{l}G+L \\
\text { hom } \rightarrow L\end{array}$ & $\begin{array}{l}\text { Regeneration of quartz, } \\
\text { crystallization of } \\
\text { carbonates, } \mathrm{Fe}^{2+} \rightarrow \mathrm{Fe}^{3+} \\
\text { late microclinization }\end{array}$ & $\begin{array}{l}\text { Colourless rock crystal, microcline II, } \\
\text { montmorillonite-muscovite, fluorite, } \\
\text { siderite, bertrandite, cassiterite, } \\
\text { goethite, hematite }\end{array}$ \\
\hline Acid III .. . & $<250$ & $7.0-5.5$ & $\begin{array}{l}\mathrm{L}+\mathrm{G} \\
\text { hom } \rightarrow \mathrm{L}\end{array}$ & $\begin{array}{l}\text { Kaolinization, } \\
\text { silicification }\end{array}$ & $\begin{array}{l}\text { Opal, adularia, earthy fluorite, } \\
\text { kaolinite, pyrite }\end{array}$ \\
\hline
\end{tabular}

Primary inclusions now consist of $M$ - melt, G - gas, $L$ - liquid and DM - daughter minerals, and homogenise to $M$ - melts, VMM - very mobile melts, $G$ - gas, $S G$ - superdense gas and $L$ - liquids.

$\mathrm{Rb}$ and $\mathrm{Cs}$ and microclinised pegmatites enriched in $\mathrm{K}_{2} \mathrm{O}(2.03-5.45 \%), \mathrm{Ca}, \mathrm{Be}, \mathrm{Ba}$ and $\mathrm{Sr}$ (table 2 , columns 8,9 ). The normative proportions of these two types are plotted in fig. 7E.

Cryolite occurs as (a) accidental pre-inclusion crystals (Kalyuzhny et al. 1962), (b) daughter minerals $(<10 \%)$ in multi-phase inclusions in topaz and quartz (Lemmlein et al. 1962; Lyakhov 1967; Lazarenko 1974) and (c) solid inclusions in quartz (Lyakhov 1967; Kalyuzhny \& Gigashvili 1972). Lemmlein et al. (1962) found an Ivigtut cryolite assemblage - cryolite, quartz, muscovite and fluorite (plus an unknown phase) - in inclusions in topaz. Homogenization under pressure formed a hydrous silicate melt at $700^{\circ} \mathrm{C}$. However, Voznyak (1971) considered that these daughter minerals were in fact accidental solid inclusions, and that homogenization occurred at $400-370^{\circ} \mathrm{C}$. Trapping of the solids took place under boiling of the mineral-forming solutions.

In the most recent evolutionary scheme for the pegmatites (Kalyuzhny \& Gigashvili 1972) (table 3 ), cryolite is assigned to the second acid stage when low $\mathrm{pH}$ values and low oxygen activity prevailed. Topaz, phenacite and cleavelandite are the dominant phases and form as crystals in the cavity void or develop metasomatically in neighbouring feldspar blocks. Zoned crystals of quartz almost stop growing and only in a few crystals are found thin zones of spotty quartz with inclusions of cryolite. Most of the quartz, together with the topaz, formed during the alteration of feldspars.

Cryolite occurrences (a) and (b) may carry up to $15 \%$ elpasolite, in addition to the more abundant halite and sylvite. Kalyuzhny (1956) records that slow heating of elpasolite inclusions in topaz gave an incongruent decomposition over $135-170^{\circ} \mathrm{C}$ to three different (?) fluoride minerals of lower refractivity. Lyakhov (1967) found that elpasolite homogenises at $230-330^{\circ} \mathrm{C}$.

Dontsova et al. (1972) considered that fractionation of oxygen isotopes in Volynian phases was related only to decreasing temperature and mineral-structure controls in a closed system. However, according to carbon isotope studies, the $\mathrm{CO}_{2}$ of the pegmatites was formed by both granitic volatiles and endogene fluids (Mamchur et al. 1975). Similarly, Naydenov et al. (1972) found that early pegmatite zones with only $4-6 \%$ at- 
mospheric Ar crystallised under closed conditions, whereas the later cavity minerals contained $30-42 \%$ atmospheric Ar.

(5) Tarbagatay, E Kazakhstan

Cryolite and other aluminofluorides occur in pegmatoid bodies within albitised riebeckite apogranites of the Large massif, N. W. Tarbagatay, E. Kazakhstan (table 2, column 11) (Beus et al. 1962; Mineev 1963 1968; Vlasov 1968, p. 95).

These apogranites lie at the northern end of the coeval Akzhaylyau massif. All rocks have been dated at $300 \pm 9$ m.y.; they intrude Lower Carboniferous sandy-argillaceous rocks. Most of the Akzhaylyau massif consists of biotite granites with lesser granodiorites, quartz syenite and pegmatites. At its northern edge are three outlying cupolas of metasomatically altered granites which are related to a regional fault zone.

The host granite for the cryolite (Large massif, $4.5 \mathrm{~km}^{2}$ ) consists of porphyritic biotite-microcline microgranites (plagioclase $\mathrm{An}_{15-12}$ ) in its central parts. The main accessories are fluorite, zircon, monazite, ilmenite and bastnäsite. These granites are slightly albitised and grade into metasomatic derivatives: riebeckite-albite granites, and albite-rich leucogranites (plagioclase $\mathrm{An}_{6-2}$ ) where the mafic minerals are destroyed and leached out. Common accessories are zircon, gagarinite and Ce-pyrochlore. The most highly metasomatised rocks occur in the exocontact zone.

Within the medium grained riebeckite apogranites of the southern part of the Large massif occur pegmatoid bodies composed mainly of albite but also containing microcline, quartz and riebeckite plus considerable quantities of altered gagarinite, bastnäsite, zircon and thorite, and sometimes also cryolite, partly altered to other aluminofluorides. In the centre of the massif, some veins and nests, up to $30 \mathrm{~cm}$ in diameter, are completely composed of cryolite, partly replaced by thomsenolite, weberite and gearksutite. Here the associated minerals are lithium micas, zircon, rutile and gagarinite. In the contact zone of the massif, accessory cryolite and thomsenolite were noted in riebeckitic and astrophyllitic metasomatites.

The typical fluoride phase of the metasomatic granites is gagarinite, the rare-earth analogue of thomsenolite. It was first found in 1958 in intensely albitised granites and associated quartz-microcline veins in Kazakhstan, and is generally accompanied by riebeckite, pyrochlore, bastnäsite and zircon (Stepanov \& Severov 1961). Disseminated fluorite is not especially widespread and only reaches significant percentages in parts of the exocontact zones and in pegmatites of the Akzhaylyau massif. Gearksutite was found with opal and secondary fluorite on the walls of old ditches and shafts along cracks in albitised rocks. The characteristic supergene fluorides of the exocontact zones are nodular creedite and gearksutite.

The formation of the riebeckite and aegirine apogranites together with their rare-metal mineralization was due to the process of intensive post-magmatic alkali-haloid metasomatism. Metasomatism occurred as a widespread diffusive process but was also concentrated along fractures and in the contact zones of the massifs. The most active components were $\mathrm{Na}, \mathrm{K}, \mathrm{Fe}^{3+}$ and $\mathrm{F}$. According to Mineev (1968), $\mathrm{AlF}_{6}{ }^{3-}$ was only one of several complex fluoriferous ions $\left(\mathrm{FeF}^{3-}, \mathrm{YF}_{6}{ }^{3-}\right.$, $\mathrm{BeF}_{4}{ }^{2-}, \mathrm{TaF}_{6}{ }^{-}, \mathrm{TaOF}_{4}^{-}$) which combined with alkalis and rare metals to promote the rare-metal mineralization. The introduced $\mathrm{F}$ and rare metals were probably derived from the deeper zones of the massif which consist of microclinised apogranite improverished in these components.

\section{(6) Zerendin massif, E Kazakhstan}

According to Ginzburg et al. (1970), cryolite has been found in the Zerendin massif of Kazakhstan. Ginzburg (1979, personal communication) has kindly reported that this massif, like locality 5, is located in E Kazakhstan. The cryolite occurs as an accessory mineral in metasomatic riebeckite granites. No detailed publication has been made yet.

\section{(7) Burpala massif, N Transbaikal}

Small broken veinlets and nests of cryolite occur in thin vein-like bodies of alkali granite in the Burpala massif (Ganzeev et al. 1969; Efimov \& Ganzeev 1972; Ganzeev, personal communication, 1978).

The vein-like bodies cut pulaskite, with a low content of nepheline, from the main intrusive phase of the massif. They consist of microcline, quartz, albite, aegirine and riebeckite. Together 
with cryolite are found plumbobetafite, zircon, catapleiite, elpidite, astrophyllite, bafertisite, neptunite, polylithionite, thorianite and (?) gagarinite. The secondary minerals are montmorillonite, bastnäsite, gearksutite, ralstonite and thomsenolite. The mineral paragenesis is considered analogous to that of the Kazakhstan apogranites (Cryolite (5) above).

Ganzeev \& Sotskov (1976) found $1.0 \mathrm{ppm} \mathrm{La}$, $3.2 \mathrm{ppm} \mathrm{Ce}, 0.5 \mathrm{ppm} \mathrm{Sm}$ and $4700 \mathrm{ppm} \mathrm{Sr}$ in the Burpala cryolite.

\section{(8) Lesser Chinga, Manchuria (North East}

China) (unconfirmed)

Two cycles of granitic activity were distinguished in Lesser Chinga according to Wittheft (1936). The younger cycle has three related types of pegmatites: (a) tourmaline-mica pegmatite, (b) feldspar-quartz types and (c) quartz veins with minerals of the type cryolite, fluorite and muscovite.

\section{(9) Younger Granites, Jos Plateau, Nigeria}

Cryolite and thomsenolite are common accessory minerals in riebeckite-albite granites from at least five of the Jurassic ring complexes of Nigeria (Amo, Jos-Bukuru, Liruei, Rop and Shere) (Mackay et al. 1949; Beer 1951 1952; Mackay \& Beer 1952; Jakobson et al. 1958; Buchanan et al. 1971).

The Kaffo granite of the Liruei complex (fig. 4) (table 2 , column 10) contains up to $6 \%$ cryolite. It is the final intrusion of the complex and was emplaced as a gently domed sheet. Bowden \& Turner (1974) consider the cryolite to have an interstitial and vein-like character in this granite and Bowden (personal communication in Blaxland, 1976) relates its presence to extensive or complete recrystallization following metasomatism by F-rich, late-stage hydrothermal fluids. Fig. 15, Plate VI of Jacobson et al. (1958) shows cryolite as a broken ring of small inclusions within large quartz phenocrysts. According to Borley et al. (1976), the peralkaline Kaffo albite-riebeckite granite is an albitised, low temperature intrusion. $\mathrm{F}$ and $\mathrm{Na}_{2} \mathrm{O}$ contents vary from $0.08-2.16 \%$ and $3.73-7.45 \%$, respectively, and show a clear positive correlation. It is not clear, however, how these elements are distributed between albite, cryolite and Na-F-rich amphiboles. Isotopically, the $\delta^{18} \mathrm{O}$ values are similar to those of normal plutonic granites and albitization was probably a cognate (autometasomatic) process occurring at temperatures close to those of final consolidation of the granite (perhaps $600^{\circ} \mathrm{C}$ ). Low $\delta^{18} \mathrm{O}$ values for coexisting riebeckitic-arfvedsonites and aegirines may be related to special features of their crystal chemistry.

Pauly \& Aho (1959) (fig. 4) divided the Kaffo granite into two main types: orthoclase granite and albite-orthoclase granite. The orthoclase granite contains little or no cryolite. The albite-orthoclase granite is more variable both in grain size and mineral proportions; notably, cryolite (a) was consistently present in the two centrally placed drill cores $(1284,-7)$ where contents increased with height and (b) was from $3-6 \mathrm{vol} . \%$ at the $20 \mathrm{~m}$ depth in the four centrally placed cores $(1284,-6,-7,-9)$ suggesting a cryolite-rich zone at this level. Flotation tests did not yield usable contents of cryolite or pyrochlore. Pyrochlore occurs in all samples from $0.1-0.8 \%$.

In general, igneous activity in the Nigerian ring complexes began with the extrusion of voluminous rhyolites and the later granite emplacement was controlled by ring-fracturing and major block subsidence. Amphibole-fayalite granites merge into the more siliceous biotite granites and riebeckite granites which may be emplaced in any order or merge into each other (Jacobson et al. 1958).

Magmatic products have frequently suffered a considerable history of local albitization and greisenization. The degree of albitization is correlated with the contents of heavy rare-earths, $\mathrm{Nb}$ and $\mathrm{Sn}$ and the morphology of columbite and zircon crystals (Williams et al. 1956; Pavlenko et al. 1960; Bowden \& van Breemen 1972). Characteristic accessories of albite-riebeckite granites are pyrochlore, cryolite, thomsenolite, astrophyllite and zircon but fluorite, thorite, ilmenite and topaz are also found. Cryolite, astrophyllite, riebeckite and aegirine are mineralogical reflections of the peralkaline character of these granites.

At the present time, the evidence from $\mathrm{Sr}$ - and $\mathrm{Pb}$-isotopes, the chemistry of the Nigerian granitic basement and melting studies has been taken to suggest that the Jurassic granite complexes were derived by progressive melting of the basement (Bowden 1970; Freeth 1972; Bowden \& 


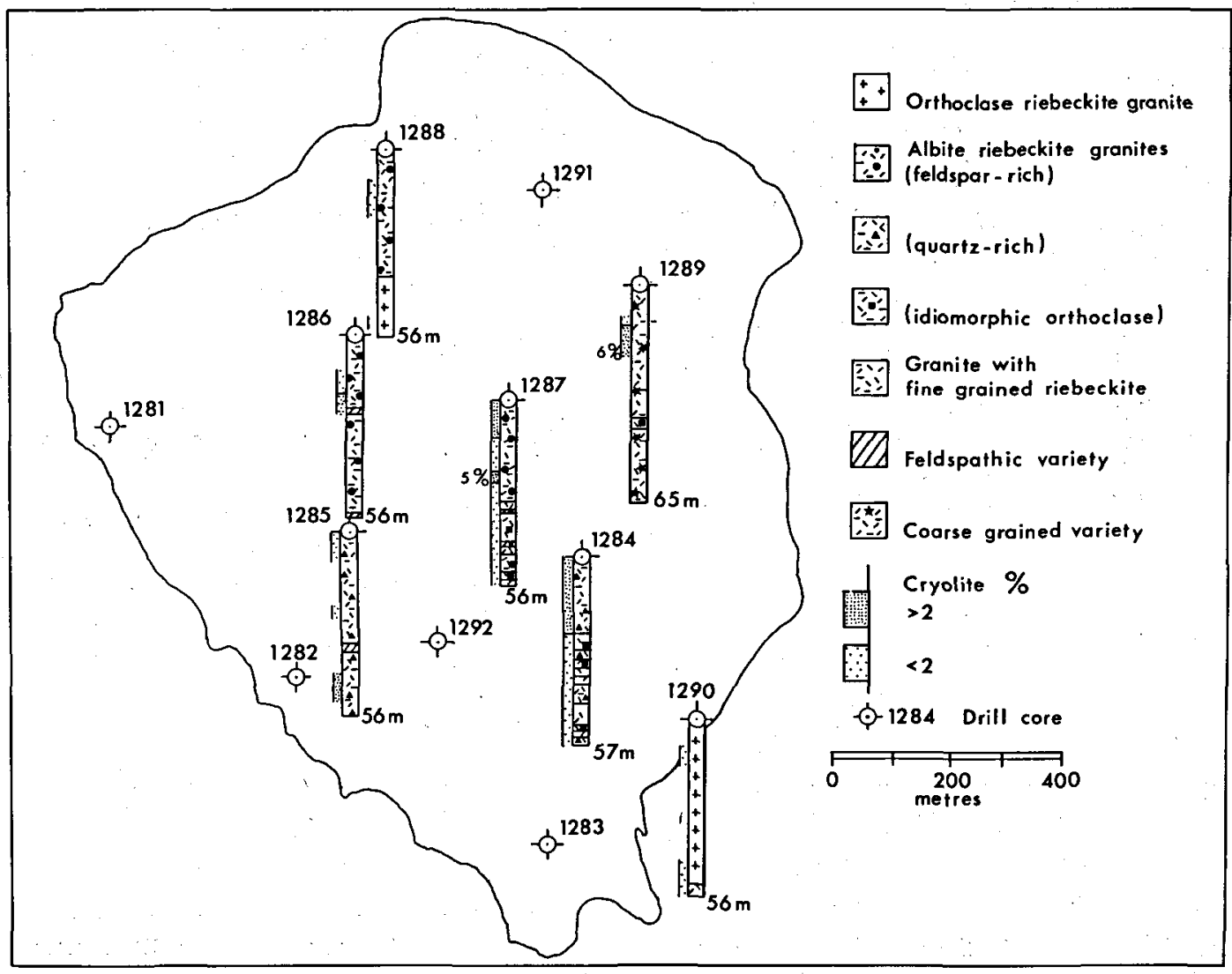

Fig. 4. Distribution of rock types and cryolite contents in drill cores through the Kaffo granite, Liruei ring complex, Nigeria (afier Pauly \& Aho 1959).

van Breemen 1972; Brown \& Bowden 1973; Bowden \& Turner 1974). The same evidence, however, has suggested a lower crustal or even upper mantle origin for the granites (Wright 1970; Eborall \& Wright 1974).

\section{(10) Erzin massif, S.E. Tuva, USSR}

In 1959 cryolite, thomsenolite, gearksutite and gagarinite were discovered in metasomatised rocks of the Erzin alkali granite - quartz syenite stock (fig. 5) (Pavlenko et al. 1960; Kudrin et al. 1965; Kudrin \& Kudrin 1968; Ginzburg \& Fel'dman 1977).

The Erzin stock, about $1.5 \mathrm{~km}^{2}$, is located in the Mongol-Tuva alkali province (Pavlenko 1974). During Hercynian time, granites of the youngest intrusive complex were injected along a deep-seated regional fault. In the first phase of the complex, biotite leucogranite plutons developed. These were followed by intrusions of alkaline and nepheline syenites, 1 to $60 \mathrm{~km}^{2}$ in area. Finally, stocks of alkaline and subalkaline granites, $1-2 \mathrm{~km}^{2}$ in area, were emplaced. The Erzin stock is confined to the junction of the regional fault and a fracture feathering from it, and was emplaced into Precambrian limestones.

Inside the stock, unaltered rocks - biotite alaskite $\left(\mathrm{An}_{20-25}\right)$ according to Pavlenko et al. (1960) but diopsidic quartz syenite according to Kudrin \& Kudrina (1968) - only occur in the footwall contact zone. Pegmatites (0.1-1.5 m wide) occur along the hanging wall contact and pegmatite veins cut the massif and enclosing rocks. Near the contact, there is formation of greisen, quartzfluorite and quartz veins, and skarn. Nearly all the stock has undergone intense autometasomatism. Four stages can be recognised: microclinization, albitization, Li-mica formation and quartzification. Characteristic minerals of these stages are: (a) plagioclase $\left(\mathrm{An}_{5-9}\right)$, hydromicas, (b) platy albite $\left(\mathrm{An}_{0-5}\right)$, riebeckite, aegirine, magnetite, columbite, ferrithorite, zircon, fluor- 


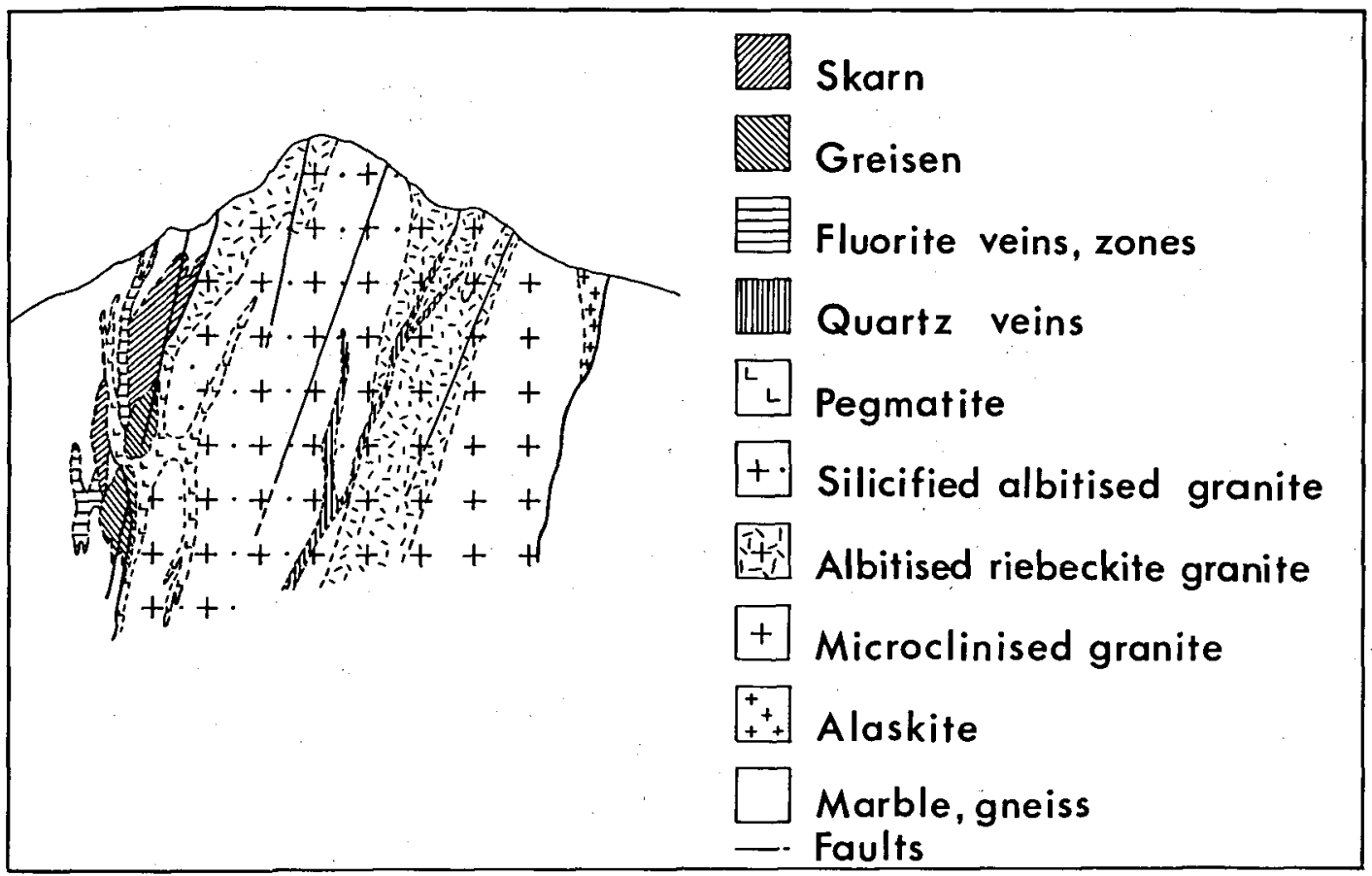

Fig. 5. Geological section through the Erzin massif, Tuva (after Pavlenko et al. 1960).

ite, (c) Li-biotite, protolithionite, zinnwaldite, cryophyllite and (d) quartz crystals with concentric rings of platy albite inclusions. The later stages are largely restricted to the central areas of the stock but also occur in metasomatic veins along periodically active fractures.

$\mathrm{Ca}$ was lost during microclinization of plagioclase and this inhibited the later formation of fluorite. The high activity of $\mathrm{Na}$ and $\mathrm{Fe}$ during stage (b) metasomatism was responsible for the appearance of cryolite and gagarinite instead of fluorite, siderite instead of calcite, and also for albite, riebeckite, arfvedsonite, aegirine and astrophyllite.

Cryolite I, thomsenolite and gagarinite are confined to stage (b) riebeckitic rocks, but form after the feldspars and riebeckite, i.e. at the end of the Na stage. The content of cryolite and thomsenolite ranges up to $5-8 \%$ but averages $2-3 \%$. These fluorides are unstable in stages (c) and (d) and gradually disappear from the rocks. Cryolite II is more rare; together with occasional siderite it lines thin cracks and together with sulphides, columbite and malacon it forms a few quartz-rich veins which cut all minerals including stage (d) quartz. It is still confined to riebeckitic zones. Powdery supergene gearksutite forms on cryolite. Fluorite is virtually confined to contact zone marbles.

During progressive albitization, columbite crystals change from platy to prismatic and acicular, and then become corroded. Zircon crystals lose their prismatic habit and become bipyramidal; their colour deepens, fractures become more common and inclusions appear, e.g. thorite. The $\mathrm{Zr} / \mathrm{Hf}$ ratios of zircons fall from 21-55 to 14-19 (Pavlenko et al. 1957). $\mathrm{HfO}_{2}$ contents increase from $1.06-3.00$ to $1.85-4.50 \%$, and values of $\mathrm{Y}, \mathrm{Th}, \mathrm{Sn}$ and $\mathrm{Ba}$ also increase. However, the $\mathrm{Nb} / \mathrm{Ta}$ ratio of accessory tantalo-niobates is unchanged (7.5-24) (Pavlenko et al. 1960).

(11) Perga granite, N. W. Ukrainian crystalline shield

Cryolite and other aluminofluorides occur as dispersed impregnations and later veins in quartzo-feldspathic metasomatic rocks (Perga granites) of the northwestern part of the Ukrainian crystalline shield (fig. 6) (Zinchenko 1968; Yurk et al. 1974; Gurov et al. 1975a).

The Perga (or Perzhansky) granite has been 


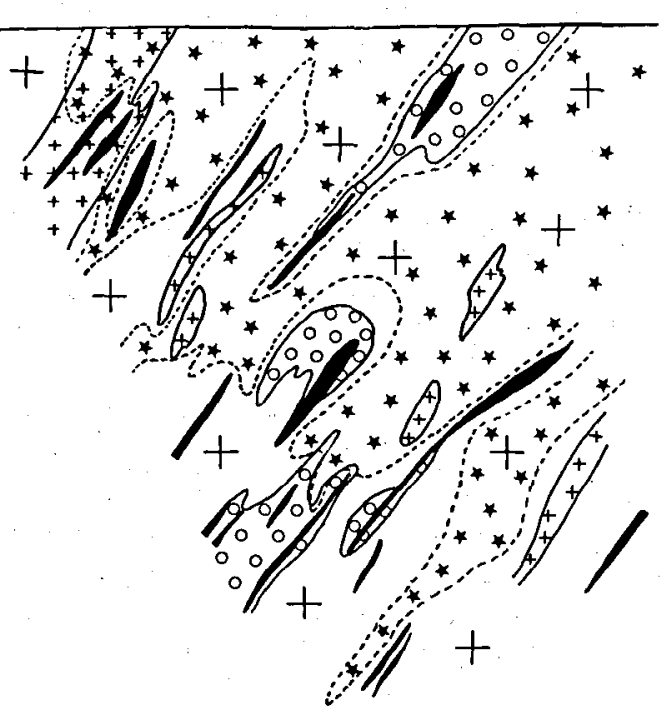

Metasomatic granitoids

Oog

Intensely metasomatised
granitoids

$\square$

Rare-metal

feldspar metasomatites

$+$

Fine-grained

granitic metasomatites

Dispersed

aluminofluorides

Fig. 6. Geological section through metasomatic granites, Perga, Ukraine (after Gurov et al. 1975a).

dated at $1200-1300$ m.y. and is a younger phase of the Korostensky igneous complex described as Cryolite locality 4 above (Gorokhov 1964). The metasomatic rocks were developed in a narrow tectonic zone (Sushchano-Perzhansky zone) subparallel to the plunge of the shield. They vary in composition from granitic metasomatites to quartz-albite-microcline rocks and microclinites with a little quartz and biotite. Multi-stage metasomatism (notably albitization and greisenization) and tectonic movements are characteristic. These processes were followed by $F$ metasomatism during which the aluminofluorides replaced the earlier quartz, feldspars, aegirine, mica and siderite. Fluorite is virtually absent reflecting the low $\mathrm{CaO}$ contents of the rocks (generally $0.15-0.40 \%$ ) and the location of $\mathrm{CaO}$ in acid plagioclases. Values up to $0.95 \% \mathrm{CaO}$ are occasionally found in cryolite-bearing granites. Intervening areas of siderophyllitic greisens contain higher $\mathrm{Ca}$ contents and fluorite. The cryolitebearing granites have high contents of alkalis, aluminium and fluorine (0.07-1.20\%) (table 2, column 12) (fig. 7E).

Dispersed concentrations of fluorides are relatively widely developed and are represented by small nests scattered through the rocks. Lenses of feldspathic metasomatites (fig. 6) possess aureoles of more intensely metasomatised apogra- nites with enhanced aluminofluoride contents, notably weberite and prosopite.

The subsequent veins of aluminofluorides are highly irregular frequently forking out and wedging out. They were intruded after and are closely associated with a group of quartz and amazonite-quartz veins. Occasionally, there are more persistent veins which are 5-8 $\mathrm{m}$ in length and $3-5 \mathrm{~cm}$ thick with bulbous bodies up to $10-15 \mathrm{~cm}$ thick containing quartz, cryolite and other fluorides. Cryolite is the earliest to form; it is often overgrown by pachnolite and thomsenolite which are corroded and replaced by weberite. Ralstonite and gearksutite are later still. Weberite is the most widely occurring fluoride and is typically intergrown . with prosopite, thomsenolite, chiolite and fluocerite. Prosopite elsewhere appears to be a primary hydrothermal phase like the cryolite; it is partly replaced by weberite, fluorite and elpasolite, and by gearksutite under supergene conditions. Only cryolite and weberite are fairly widespread (Mel'nik \& Rasumeeva 1969; Gurov \& Gurova 19701973 1974; Gurov et al. 196919701971 1972 1975a; Yurk et al. 1970 1974). Associated minerals include fluocerite, phenacite, genthelvite, siderite, aegirine, riebeckite, ferrimuscovite, columbite, bastnäsite, fluorite, hematite, molybdenite and galena (Zinchenko 1968; Gurov \& Marchenko 1970; Gurov 
et al. 1975b). Cryolite contains $0.45 \% \mathrm{~K}, 2.8$ ppm Cs, 10 ppm Rb, 30 ppm Mn, 50-100 ppm Ti, 40-50 ppm Cu and 2-5 ppm Ag (Zinchenko 1968).

Two-phase fluid inclusions in cryolite homogenise at $470-420^{\circ} \mathrm{C}$ in greisenised apogranite and $440-370^{\circ} \mathrm{C}$ in veins from apogranites, quartzofeldspathic metasomatites and microclinites. Lower temperature inclusions, $335-275^{\circ} \mathrm{C}$ and $230-195^{\circ} \mathrm{C}$, are probably related to hydrothermal replacement of cryolite by the other aluminofluorides (Yurk et al. 1974).

\section{(12) East Siberia, USSR}

Feldspar and feldspar-quartz metasomatites, related to regionally metamorphosed and folded rocks in $\mathrm{E}$ Siberia, contain cryolite, other fluorides and Ta-Nb ores (Arkhangel'skaya 1968 1974; Kudrin 1972; Ginzburg \& Fel'dman 1977).

The metasomatites have developed along a zone of activation at the contact of Archaean and Lower Proterozoic structures and have been dated at 1786-1919 m.y. The zone is characterised by widespread palingenesis, dislocation metamorphism and alkali metasomatism. The metasomatites form a plate-like body, 500-600 $\mathrm{m}$ thick and many $\mathrm{km}$ long, which is conformable with a gently dipping fracture within the activation zone. The surrounding metasediments are folded and have reached greenschist to amphibolite facies. Inside the metasomatites are xenolithic relics of incompletely replaced schists, quartzites, gneisses and granites.

The metasomatites are structurally variable banded, pseudo-stratified, pseudo-gneissose, streaky and reticulate; they show variable porphyroblastic textures and replacive relations between all the rock-forming minerals. They contain up to $2-4 \% \mathrm{~F}$, generally $0.05-1.0 \%$, but very little $\mathrm{Ca}$ and $\mathrm{Mg}$ (table 2, columns 13,14 ). Agpaitic coefficients reach 1.2 or more and high $\mathrm{Na} / \mathrm{K}$ ratios are typical.

Metasomatic zonation is expressed by (a) rear zones in the core of the activation zone which consist of aegirine and aegirine-amphibole rocks with the composition of alkali granosyenites, (b) intermediate zones comprising amphibole metasomatites which are compositionally alkaline granites, (c) the frontal (peripheral) zones of granite-like biotite metasomatites and (d) an outer aureole around the metasomatic bodies proper.

Each zone has its own assemblage of fluorides. In the rear zones there is cryolite and ralstonite, as well as alteration products of cryolite (pachnolite and thomsenolite). In the intermediate zones are cryolite and gagarinite. The peripheral zones have retained some of the $\mathrm{Ca}$ of the original rocks and typically possess rare-earth fluorite, normal fluorite and gagarinite. Fluorite and chevkinite are found in the outer aureole. In a narrow band between the peripheral and intermediate zones, at the onset of albitization, fluocerite appears. $\mathrm{Mg}$ - and Ca-bearing sodic fluorides (weberite, gagarinite, neighborite $\left(\mathrm{NaMgF}_{3}\right)$ ) only occur locally where Na-rich solutions avoided the amphibole metasomatites and reached rocks of the frontal zones which had retained some $\mathrm{Ca}$ and Mg.

Cryolite is restricted to areas with sodic amphiboles - Fe-arfvedsonite, riebeckite and ferrihastingsite. REE-Pb-bearing pyrochlore and zircon are typical accessories. Cryolite and the secondary pachnolite and thomsenolite occasionally constitute $2-10 \%$ of the rocks and are potential by-products of the mining (Ginzburg et al. 1970). Cryolite contents of apogneissic schists $(0.6-1.4 \%)$ tend to be higher than apogranitic gneisses (0.0-0.3\%) (Kudrin 1972, Fig. 5). Isolated pegmatitic areas with quartz, feldspar and amphibole may also contain cryolite, gagarinite and zircon.

The $\mathrm{Ta}-\mathrm{Nb}$ deposit is defined by the presence of pyrochlore which is fairly evenly scattered through the metasomatic rocks. However, contents of $\mathrm{REE}$ and $\mathrm{Pb}$, along with the percentage of pyrochlore, tend to increase into the rear amphibole-aegirine zone.

According to homogenization temperatures of fluid inclusions in the rock-forming minerals of the metasomatites, temperatures varied from $300-350^{\circ} \mathrm{C}$ in the frontal zones up to $500-600^{\circ} \mathrm{C}$ in the rear zones.

(13) Lake Khanka, Maritime Province, USSR Near Lake Khanka, about 120 km north of Vladivostok, cryolite is occasionally found in mica-fluorite ores formed by the greisenization of limestone xenoliths in granite (Govorov 1958; Rub 1960).

The mica-fluorite ores occur as lenses and pipes at the margin of Mid Palaeozoic leucogra- 
nite intrusions associated with complexes of biotite granite and hybrid rocks of syenitic to basic composition. During granite evolution F contents increased; they reach $0.5-0.54 \%$ in the liquid phase of fluid inclusions in quartz. Fluid inclusions in the mica-fluorite ores also show abundant $F$ with all other anions negligible (Rub 1972).

The earliest stage of post-magmatic alteration of the leucogranites produced muscovite-quartz greisen veins and albite-oligoclase veins related to albitization in the apical parts of the intrusions (Govorov 1958). Marbles and skarns then formed at the contacts of the granite with limestone. Subsequent autometasomatism of the granite produced simple muscovite-quartz greisens but a later F-richer pulse converted these to quartz-topaz greisens and converted xenoliths of limestone to the mica-fluorite rock type. In this greisen type, unusually low amounts of $\mathrm{Si}$ were introduced along with the alkalis, $\mathrm{Al}, \mathrm{F}, \mathrm{B}, \mathrm{H}_{2} \mathrm{O}$ and rare metals $(\mathrm{Sn}, \mathrm{W}, \mathrm{Be})$.

Mineralogically, the mica-fluorite ores consist of fluorite $(55-75 \%)$, micas $(25-40 \%)$, tourmaline, phenacite, chrysoberyl, calcite, scapolite, cassiterite, sellaite and graphite; there is occasional cryolite, topaz, quartz, euclase, beryl, corundum, diaspore and apatite. Cryolite occurs as anhedral grains, $0.01-0.3 \mathrm{~mm}$ or rarely 0.8 $\mathrm{mm}$ across. It is closely associated with $\mathrm{Li}$ micas or more seldom with fluorite and topaz which it replaces. It is perhaps significant for the formation of the cryolite that relatively high amounts of $\mathrm{K}(0.23-2.60 \%)$ and $\mathrm{Na}(0.10-0.67 \%)$ (usually impoverished in greisens) were introduced and lead to the formation of K-micas (muscovite) and Na-brittle micas (ephesite).

(14) Goldie carbonatite, Texas Creek, Fremont County, Colorado

The Goldie carbonatite is part of an extensive dyke halo around the mesozonal-catazonal McClure Mountain - Iron Mountain alkalic complex of south-central Colorado (Heinrich \& Dahlem 1970; Heinrich 1977). The complex is probably close to $600 \mathrm{~m}$.y. in age. It consists of peridotite, gabbro, hornblende syenite, ijolite and nepheline syenite and possesses a dyke halo of cogenetic lamprophyres (mainly camptonites) and carbonatites up to $27 \mathrm{~km}$ from the complex.

The three main carbonatitic types are: (a) sö- vites and dolomitic sövites with few accessories, (b) feldspathic carbonatites which grade into feldspathic Th-REE veins and (c) sövites rich in barite and fluorine minerals, or late amethyst (Heinrich \& Shappirio 1966).

The Goldie carbonatite veins were intruded alongside and altered a lamprophyre sill which occupied a fracture for at least $250 \mathrm{~m}$ (Heinrich \& Quon 1963; Heinrich 1977). The lamprophyre contains microphenocrysts of olivine and titanian augite set in a hornblende-magnetite-plagioclase matrix. Six carbonatite veins, about $10-80 \mathrm{~cm}$ in width and 1-100 $\mathrm{m}$ in length, occur above and below the sill. The lamprophyre and carbonatite veins are locally separated from country gneisses by aplites and fenites. The aplites are partly replaced by hematite and calcite. The fenites consist of riebeckite, aegirine and potash feldspar and vein and replace the gneisses. The carbonatite veins (type (c)) consist of radioactive, hematite-stained, coarse calcite with local masšes of barite and green fluorite. Minor niobian rutile and replacive albite occur.

On breaking all rock types of the deposit a fetid gas of fluorinated hydrocarbons $\left(\mathrm{C}_{5}\right.$ and $\mathrm{C}_{6}$ hydrocarbons, $\mathrm{F}_{2}, \mathrm{HF}$ and $\mathrm{F}_{2} \mathrm{O}$ ) is emitted. The fluorine was derived from structurally degraded radioactive fluorite; the hydrocarbon gases may represent primary inclusions (Heinrich \& Anderson 1965).

Aluminofluorides occur in four of the Goldie carbonatite veins but are only abundant in two. They occur as nodules and bands replacing the carbonatite. The nodules are up to $25 \mathrm{~cm}$ long and irregular to ellipsoidal in form (table 2, column 17). Crude zoning of the nodules can be ideally approximated to: (a) cryolite core, (b) weberite + ralstonite, pachnolite, euhedra and groups of prosopite, (c) prosopite needles in comb-structure, (d) aggregates of calcite, purple fluorite and diaspore and (e) rims of secondary hematite, purple fluorite and sericite. Elpasolite and gearksutite are less certainly identified. Apparently only cryolite can occur as nearly monomineralic nodules.

Heinrich (1977) distinguishes three main stages in the formation of the Goldie carbonatites: (a) marginal fenite and main carbonatite, (b) aluminofluorides - cryolite to prosopite, (c) purple fluorite stage. Cryolite formation is due to reaction between late residual carbonatitic fluids 
rich in $\mathrm{Na}$ and $\mathrm{F}$ and primary carbonatitic calcite. The Ca released by this reaction formed pachnolite, prosopite and fluorite later in the replacement sequence. Heinrich (1977) considers that the Goldie carbonatites offer direct evidence for the importance of $\mathrm{Na}, \mathrm{F}$ and gaseous carbon compounds in carbonatitic fluids. These primary components are usually lost during degassing and fenitization.

The related amethyst-bearing silico-carbonatites occur at the greatest distance from the McClure Mountain - Iron Mountain complex and were emplaced violently. They exhibit a multi-stage development from magmatic feldspar-rich and carbonate-rich phases to hydrothermal overgrowths, comb-structure veins and smoky and amethystine quartz (Heinrich \& Shappirio 1966). These late-stage mobile components may have been retained because of the fairly deep level of the emplacement.

An interesting contrast is provided by carbonatite dykes, $6 \mathrm{~km}$ to the southwest, which are associated with the Gem Park mafic-ultramafic complex. They have been divided into the following types (with median F contents): dolomite-pyrochlore $(0.03 \%)$, dolomite-apatite $(0.04 \%)$, dolomite-blue amphibole-pyrochlore $(0.11 \%)$ and dolomite-barite-monazite $(0.04 \%)$. Aluminofluorides have not been reported (Parker \& Sharp 1970).

(15) Francon quarry, Montreal Island, Quebec, Canada

Colourless to yellow cryolite, more commonly crystalline than massive, occurs in cavities with calcite, weloganite ( $\mathrm{Sr}-\mathrm{Zr}$ carbonate) and dawsonite in a silico-carbonatite sill at the Francon quarry, St-Michel, Montreal Island (Sabina et al. 1968).

A related sill from the same quarry has been described by Jambor et al. (1976). It is $2 \mathrm{~m}$ thick with a $4-5 \mathrm{~cm}$ thick chilled margin against the host Ordovician limestones. Vesicles and cavities form several percent of the sill and are normally lined with quartz, calcite, plagioclase and dawsonite $\left(\mathrm{NaAl}\left(\mathrm{CO}_{3}\right)(\mathrm{OH})_{2}\right)$. The chilled selvages are essentially microcrystalline intergrowths of dawsonite and feldspar with $5-10 \%$ dawsonite pseudomorphs probably after analcime, plus minor albite. In the centre of the sill the same pseudomorphs are set in a fine grained matrix of orthoclase and dawsonite, with occasionally dolomite, aegirine-augite, siderite and analcime (partly after albite) and accessory amounts of magnetite, pyrochlore, zircon and apatite. Fluorite and cryolite are minor constituents. In one part of the quarry, the percentage of carbonate decreases and the sill approaches alkali syenite in composition.

The composition of the sill is given in table 2, column 18. The high contents of $\mathrm{Zr}, \mathrm{Nb}$ and $\mathrm{Sr}$ are held by weloganite, zircon, pyrochlore and strontianite (Steacy \& Jambor 1969).

The cryolite-bearing cavity assemblage and a dawsonite-fluorite-sphalerite assemblage only occur in small areas of particular sills in the quarry. The most common cavity assemblage is quartz-calcite-dawsonite \pm strontianite, weloganite, dresserite, fluorite and analcime (Sabina 1976). Weloganite and dresserite ( $\mathrm{Ba}-\mathrm{Al}$ carbonate) (Jambor et al. 1969) are only known from this locality.

The alkali sills of the Francon quarry are believed to be satellitic bodies related to the Mesozoic plutonic intrusions of Mount Royal, part of the Monteregian alkalic province (Clark 1972; Philpotts 1974). A close comparison to the silico-carbonatite sill is afforded by a dawsonite-fluorite-bearing feldspathic dyke in downtown Montreal (Stevenson \& Stevenson 1975). The Oka carbonatite is also located in the Monteregian province.

(16) Green River Formation, Wyoming-Utah-Colorado

Sparse amounts of authigenic fluorides - fluorite, cryolite, and neighborite $\left(\mathrm{NaMgF}_{3}\right)$ - occur locally in the Eocene trona-rich Green River Formation of western USA (Chao et al. 1961; Milton 1971 1977).

In Colorado, cryolite forms beds and lenses a few $\mathrm{mm}$ in thickness. It also occurs in dolomitic oil shales of Colorado along with dawsonite and nahcolite $\left(\mathrm{NaHCO}_{3}\right)$. Fluorine (700-2100 ppm) is located in anhedral grains $(5-10 \mu \mathrm{m}$ in diameter) of fluorite and cryolite in rich oil shales (table 2, column 19) (Desborough et al. 1976). Other F-rich minerals in the Green River Formation include magnesioarfvedsonite and fluorapatite (Milton 1971 1977).

The origin of the Green River Formation is still under discussion (see p. 36). Most hypotheses 
invoke the influx and evaporation of alkaline spring and river waters rich in $\mathrm{Na}, \mathrm{Ca}, \mathrm{Mg}, \mathrm{CO}_{3}$ and $\mathrm{Cl}$, and related to nearby alkalic volcanism. Freshwater facies with oil shales, saline alkaline facies, sandstones and volcanic tuffs all occur. The dominance of oil-shale hydrocarbons and iron sulphides, and the absence of primary sulphates, indicate reducing conditions during sediment accumulation.

(17) Lovozero massif, Kola Peninsula, USSR

In the cracks of slightly weathered villiaumite (NaF)-bearing nepheline syenites of the Lovozero agpaitic massif were found white porcelain-like crystals which represent a cryptocrystalline mixture of supergene cryolite and opal. The presence of cryolite was confirmed by X-ray studies (Semenov, personal communication in Stepanov 1963, p. 47).

According to Dorfman et al. (1967), Semenov only found cryolite in a single sample. These authors were unable to confirm its presence in other samples and consider it to be very rare (see $p$. 36).

(18) Khibina massif, Kola Peninsula, USSR Cryolite and dawsonite occur in siderite-rich veinlets cutting foyaite from the Khibina alkaline massif (Kozyreva et al. 1976). They are associated with burbankite and pyrite. The colourless cryolite occurs as aggregates, up to $1 \times 1 \mathrm{~cm}$, in the central zone of the veinlets and as pseudo-cubic crystals, up to $1 \mathrm{~mm}$ in size, in small vughs. It contains minor and trace element levels of $\mathrm{Mn}, \mathrm{Ca}, \mathrm{K}, \mathrm{CO}_{2}, \mathrm{Mg}, \mathrm{Fe}, \mathrm{Zn}, \mathrm{Sr}, \mathrm{Ti}, \mathrm{Pb}, \mathrm{Zr}$ and Mo. The aggregates of thread-like dawsonite crystals are generally found in the centre of large cryolite aggregates.

The formation of cryolite and dawsonite in the carbonatised rocks of this massif is connected with the dissolution of the nepheline and alkali feldspar by fluocarbonate solutions (Kozyreva et al. 1976) (see p. 36). Dawsonite appears to have formed after the cryolite.

(19). Yellowstone Park, W USA (unconfirmed) According to Day (1887, p. 693), a new discovery of cryolite in Yellowstone Park had recently been made. No details were then available, and the report seems never to have been confirmed.
(20) Earth, soil (unconfirmed)

The mineralogical manual of Lewis \& Hawkins (1931, p. 48) records that cryolite occurs "on rocks, walls, earth; in earth of some caves; in soil". There is no mention of cryolite localities known at that time or of the igneous milieu.

Modern papers and soil abstract journals carry no mention of cryolite in soil (McIntyre 1945; Robinson \& Edgington 1946; Allmann \& Koritnig 1973). Addition of $F$ to soils in superphosphate, $\mathrm{BaSiF}_{6}$ or alkali metal fluorides probably results in ultimate combination as $\mathrm{CaF}_{2}$, apatite or substitution for $\mathrm{OH}^{-}$ions in $\mathrm{Al}(\mathrm{OH})_{3}$ (Bower \& Hatcher 1967). It is known, however; that the addition of $\mathrm{F}^{-}$ions releases $\mathrm{Al}$ from the structure of the amorphous mineral allophane $\left(\mathrm{Al}_{2} \mathrm{SiO}_{5} \cdot \mathrm{nH}_{2} \mathrm{O}\right)$ - which is common in volcanic soils - with formation of $\mathrm{AlF}_{6}{ }^{3-}$ ions which may eventually yield cryolite (Birrell 1961).

Modern accounts of cave mineralogy, e.g. Davies (1958), Bridge (1968 1973) and cave abstract journals carry no reference to cryolite or other aluminofluorides.

(21) Tristan da Cunha, South Atlantic (unconfirmed)

A mineral which could be cryolite or weberite from its optical properties is mixed with hierarite $\left(\mathrm{K}_{2} \mathrm{SiF}_{6}\right)$ in yellow warty fumarolic crusts on trachyandesite lava from Tristan da Cunha (Baker et al. 1964). Ralstonite, cryptohalite and (?) thomsenolite also occur.

\section{Sallent, Spain (discredited)}

According to Heinrich $(1977$, p. 44), correspondence with a Spanish mineralogist revealed that no Spanish mineral collection contained cryolite from this locality and recent collecting at Sallent had failed to find cryolite.

\section{Evaporite deposits, Bashkir ASSR, USSR (discredited)}

According to Mineralogical Abstracts (1949, p. 445), cryolite was reported from the Lower Permian lagoonal evaporites of Bashkiria by Strakhov \& Borneman-Starynkevich (1946). Examination of the original article, however, indicates that cryolite is not even mentioned, by name or formula. 


\section{Aluminofluorides outside cryolite localities}

Cryolithionite, jarlite and chiolite have not been found in cryolite-free localities.

Elpasolite

Elpasolite was found in:

(22) sublimates within the crater of the Nyiragongo volcano, East African Rift, Zaire (Herman et al. 1960). Stalactites of aphthitalite $\left(\mathrm{K}_{3} \mathrm{Na}\left(\mathrm{SO}_{4}\right)_{2}\right)$ in concentric layers and crusts are composed of gypsum, thenardite and accessory elpasolite, halite, sylvite, hierarite, $\mathrm{KCaF}_{3}$, $\mathrm{KMgF}_{3}$ and amorphous sulphates.

Nyiragongo has extruded nephelinites which are extremely alkaline $\left(\mathrm{Na}_{2} \mathrm{O}\right.$ and $\mathrm{K}_{2} \mathrm{O}$ about $6 \%$ ) and undersaturated (Pouclet 1973). The exceptionally high $\mathrm{K} / \mathrm{Na}$ ratios compared with other basaltic eruptions presumably explain the development of elpasolite (a $\mathrm{K}-\mathrm{Na}$ aluminofluoride) rather than ralstonite (a $\mathrm{Na}-\mathrm{Mg}$ aluminofluoride) which is more abundant in basaltic environments.

Pachnolite.

Pachnolite has been found:

(23) together with thomsenolite, ralstonite, gearksutite and other fluorides (sellaite, fluorite, gagarinite, neighborite) in miarolitic cavities from the elpidite soda granite (ekerite) of Gjerdingen in the Oslo alkali igneous province, Norway (Sæbø 1966; Raade 1972; Raade \& Haug, personal communication, 1977). This late fluoride assemblage was not found in cavities of ordinary biotite granite (Drammen granite) or of syenite; instead a zeolite and carbonate assemblage occurs. $\mathrm{Ti}$ and $\mathrm{Zr}$ are characteristic elements of the ekerite cavity minerals. The host ekerite is a peralkaline granite and carries aegirine and/or riebeckitic arfvedsonite (Dietrich et al. 1965).

(24) as transparent, thick tabular crystals, up to $0.3 \mathrm{~cm}$ long, in the complex granite pegmatite at Hagendorf-Süd, Bavaria (Mücke 1977).

Thomsenolite - see Pachnolite (23)

Carlhintzeite

(24) Carlhintzeite was recently described from a single museum specimen from the Hagendorf granite pegmatites, Bavaria; the exact locality is unknown (Dunn et al. 1979). It is associated with rockbridgeite, pyrite, strengite and apatite and is younger than the first three of these phases. It formed during the hydrothermal alteration of the primary triphylite, the precursor of the secondary phosphate minerals.

Weberite - see Ralstonite (35)

Ralstonite

Ralstonite exists outside (confirmed) cryolite localities:

(21) in warty crusts associated with halite, hierarite and (?) cryolite or weberite on trachyandesite lava from Tristan da Cunha, South Atlantic (Baker et al. 1964). Fluorite and thomsenolite were also tentatively identified. The bleached lava, though without aluminofluorides, was reproduced by attack with HF fumes over about 8 hours.

(25) as small crusts and stalactites in fumarole deposits on basalt from Vesuvius, Italy (Carobbi 1936; Carobbi \& Cipriani 1951). It occurs in mixtures with merkellite, halite, erythrosiderite and other minerals.

(26) in fumarole deposits $\left(170-98^{\circ} \mathrm{C}\right)$ and $\mathrm{HF}$ metasomatised basalts $\left(300-200^{\circ} \mathrm{C}\right)$ from Klyuchevsky volcano, Kamchatka, USSR (Naboko 19411957 1959a, b). The Klyuchevsky fumarolic gases contain $2 \% \mathrm{~F}$ on a dry, air-free basis, which is higher than other Kamchatka volcanoes.

During HF metasomatism of basalts, $\mathrm{Si}$ and $\mathrm{Fe}$ volatilise in $\mathrm{F}$ compounds, and $\mathrm{Na}$ and $\mathrm{K}$ are slightly volatilised appearing in fumarolic sublimates as malladrite $\left(\mathrm{Na}_{2} \mathrm{SiF}_{6}\right)$ and hierarite $\left(\mathrm{K}_{2} \mathrm{SiF}_{6}\right)$. Other elements are retained in the basalt which is bleached white to a loose mass of fluorides (ralstonite, fluorite and others). Analyses of two bleached rocks recorded 22.4 and $43.4 \mathrm{wt} . \% \mathrm{~F}$.

(27) as pseudomorphs after creedite, fluellite or sellaite in clay gouge of the oxidised zone of the Upper Kayraktin W-Bi ore body, Central Kazakhstan (Stepanov \& Moleva 1962). Associated minerals include gearksutite, nontronite and jarosite.

(28) in fumarolic fractures of autometasomatised alkali trachytic tuff associated with opal, maghemite and other minerals at $S$. Prisco, Caserta, Italy (Di Girolamo \& Franco 1968).

(29-33) in fumaroles from five localities in 
Central America: Pacaya and Santiaguito, Guatemala; Izalco, El Salvador; Cerro Negro, Nicaragua and Arenal, Costa Rica (Stoiber \& Rose 1969 1974) (see p. 33).

(34) in fumaroles $\left(125-100^{\circ} \mathrm{C}\right)$ of the El Misti strata volcano, S. Peru, together with sulphur, anhydrite and gypsum (Birnie \& Hall 1974). A juvenile source is indicated for the parent water of the condensates, according to deuterium and oxygen isotope analyses.

(35) in fumeroles $\left(>150^{\circ} \mathrm{C}\right)$ from the basalt-andesite volcano of Deception Island, South Shetlands (Viramonte et al. 1976). These fumaroles are zoned, with fluorite in the hottest zones and weberite and then ralstonite in outer, cooler zones.

(36) as a common phase along with sulphur, opal, gypsum and thenardite $\left(\mathrm{Na}_{2} \mathrm{SO}_{4}\right)$ in incrustations around the vents and fumaroles of Kilauea volcano, Hawaii (Naughton et al. 1976).

\section{Prosopite}

Prosopite exists away from cryolite occurrences as follows: (37) Altenberg, Saxony (Scheerer 1854; Gemitz 1876; Pudovkina \& Pyatenko 1970). Prismatic crystals of prosopite occur on the walls of cracks in quartz porphyry and quartzite in the Altenberg tin deposit of the Erzgebirge. Prosopite is almost completely replaced by nacrite, fluorite or both of these minerals. The deposit is characterised by intense F-rich greisenization and hydrothermal alteration of a granite stock and enclosing quartz porphyry (Baumann \& Schlegel 1967).

(38) Dugway, Utah (Hillebrand 1899). Prosopite crystals occur with quartz, fluorite and native silver in cracks in slate and (?) trachytic rock. The green prosopite is mixed with supergene copper minerals.

(39) Santa Rosa, Zacatecas, Mexico (Dunn \& Fryer 1976). The blue prosopite, associated with azurite and containing $1.39 \% \mathrm{Cu}$, is of gem quality and constitutes a possible substitute for turquoise.

Schlaggenwald, Czechoslovakia and Mt. Bischoff, Tasmania are regarded as insecurely established occurrences (Stepanov 1963, pp. 81-82).

\section{Gearksutite}

Gearksutite, in addition 'to occurring at many cryolite localitities, has been recorded from:
(23) see Pachnolite.

(27) see Ralstonite.

(40) hydrothermally altered rhyolitic wall rocks next to the upper oxidised portion of a small fluorite-barite vein near Wagon Wheel Gap, Colorado (Larsen \& Wells 1916). The vein is closely associated with high temperature $\left(57-66^{\circ} \mathrm{C}\right)$ springs almost certainly related to the Miocene volcanism of this area (Emmons \& Larsen 1913) (table 4, column 6).

(41) clayey greensand containing glauconite and F-rich phosphatic nodules at Gingin, Western Australia (Simpson 1920).

(42) a clay bed in limestone probably after interaction with $\mathrm{F}$-bearing hot spring water between Hot Springs and Warm Springs, Virginia (Henderson 1929).

(43) volcanic ash of the island Vulcano, Italy (Bernauer 1941). Gearksutite occurs as veinlets, nodules, earthy masses and as pseudomorphs after plagioclase or volcanic glass.

$(44,45)$ cavities of quartz veins with kaolin at the Belukha and Bukuka wolframite deposits, Transbaikal. The mineral was originally called paragearksutite (Smolyaninov \& Isakov 1946); it has more alumina and less fluorine than gearksutite, but X-ray data are similar (Korzhinskiy et al. 1960).

(46) oxidised breccia zones of fluorite-bearing, $\mathrm{U}$ ore bodies in quartz monzonite, Marysvale, Utah (Gruner et al. 1951).

(47-51) a number of Mo-W, Sn and fluorite deposits where it occurs directly below the zone of oxidation in spaces among unaltered pyriteand fluorite-containing ore in association with halloysite, montmorillonite and creedite. It also occurs in the oxidation zone of these deposits with halloysite, creedite, hydrohematite, limonite and nontronite, sometimes with supergene fluorite, chukhrovite, anglesite, brochantite, ilsemanite and other minerals. Examples in the USSR are: Northern Kounrad, Karaoba, Upper Kayraktin and many other deposits in central Kazakhstan (Chukhrov 1960; Ermilova et al. 1960; Stepanov \& Moleva 1962) and the Beluka and Bukuka (see Gearksutite $(44,45)$ ), Kalanguy, Etika and Dzhida deposits in Transbaikal (Soloviev \& Levando 1958; Grigoriev \& Dolomanova 1959; Povilyatis 1960).

At Dzhida (51), there is a characteristic association of quartz-hübnerite veins with the 
gearksutite (Korzhinsky et al. 1960). Replacement of muscovite and fluorite by gearksutite resulted from greisen reactions, with subsequent hydrothermal deposition of quartz and even of heulandite and aragonite. The mineralization is thought to be associated with Mesozoic intrusions of alaskite granites and granite porphyries (Povilyatis 1960).

$(52,53)$ the weathering crust of granito-pyroxenic skarns with $\mathrm{W}, \mathrm{Pb}$ and $\mathrm{Zn}$ mineralization in association with nontronite, creedite, supergene fluorite, limonite and halloysite in deposits of Akmaya and Batistay in central Kazakhstan (Ermilova 1963a).

(54) the oxidised zone of a fluorite-bearing iron ore body at Karasug, Tuva (Khomyakov et al. 1964) (see Tikhonenkovite).

(55) from quartz-fluorite veins of the Manzhinsk fluorite deposit where it is associated with calcite, viseite and kaolinite (Arkhipchuk 1971). The veins and concretions of gearksutite occur as dense white masses formed during the terminal stages of hydrothermal mineralization at $<130^{\circ} \mathrm{C}$.

(56) among the quartz-fluorite formations of the Sor Cu-Mo deposit, USSR (Sotnikov et al. 1971). Fluorite impregnation is confined to potash feldspar and albitised metasomatites. During the final, second phase of the ore-forming process clay-like masses show the following evolution: gel-like concretions - allophane, fluorite-gearksutite, quartz, pyrite, fluorite-halloysite, quartz, fluorite and pyrite.

\section{Tikhonenkovite}

(54) Tikhonenkovite was discovered in fissures and druses in limonite-hematite ores, with gearksutite, fluorite, celestite, strontianite, and barite in the oxidation zone of siderite-rich ores of Karasug in the western part of the Tannu-Ola Range, Tuva (Khomyakov et al. 1964).

\section{Yaroslavite}

(57) Yaroslavite was first located in the oxidation zone of banded sellaite-tourmaline-fluorite ore in a fluorite-rare metal deposit in Siberia (Novikova et al. 1966). It occurs as oval or spherical aggregates with radiating fibrous structure on fluorite in solution cavities of sellaite.

\section{Usovite}

(58) Usovite was discovered in a fluorite vein near the Upper Noiby River in the Yenisei region of Siberia (Nozhkin et al. 1967; Povarennykh et al. 1974). The usovite is intergrown with fluorite. The vein also contains phengite, zeolites and halloysite and is related to metasomatic feldspathic formations and alkali syenites.

\section{Calcjarlite}

(58) Calcjarlite was discovered in association with phengite, thorite, usovite, daphnite, zeolites, halloysite and hydromica in Proterozoic quartz-mica schists at the Upper Noiby River in the Yenisei Range, USSR (Nozhkin et al. 1970; Povarennykh 1973). It was first reported as jarlite. The calcjarlite forms colourless radial aggregates in usovite.

\section{Creedite}

Away from cryolite localities, creedite has been found:

(27) see 62-68.

(40) in white halloysite clay or associated with fluorite at Wagon Wheel Gap, Creede Quadrangle, Mineral County, Colorado (Larsen \& Wells 1916; Foshag 1921) (see Gearksutite (40)).

(48) see $62-68$.

$(52,53)$ in the weathering crust of granito-pyroxenic skarns with $\mathrm{Pb}-\mathrm{Zn}$ or $\mathrm{W}$ mineralization in association with nontronite, halloysite, gearksutite, supergene fluorite, limonite and chrysocolla in the central part of Kazakhstan at Batistay, Akmaya and elsewhere (Miroshnichenko 1955).

(59) with halloysite and wad from the oxidised zone of a fluorite-quartz-gold vein deposit at Granite, Nevada (Foshag 1932).

(60) in vughs and as massive cement for brecciated quartzite, shale and sulphides in faults which cut the main vein system of the tin mine at Colquiri, Bolivia (Herzenberg 1949; Frenzel 1953; Campbell 1947; Cook 1975). The primary phase of mineralization involved hydrothermal replacement of the host sediments by chlorite, cassiterite, fluorite, quartz and sulphides of $\mathrm{Sn}$, $\mathrm{Zn}, \mathrm{Fe}, \mathrm{As}, \mathrm{Cu}$ and $\mathrm{Pb}$. Subsequent brecciation lead to the development of cavity deposition of siderite, pyrite, magnetite and marcasite. The creedite-bearing zone, less than $100 \mathrm{~m}^{2}$, occurs at the 205 and $236 \mathrm{~m}$ levels. Well-crystallised vughs of creedite indicate primary deposition from a 
late, third pulse of hydrothermal activity. The creedite is associated with limonite, clay and pyrite.

(61) in association with pyrite, galena, fluorite, carbonates and clay minerals at Darwin, California (Pabst 1952). It occurs embedded in pyrite and also lines vughs.

$(27,48,62-68)$ in considerable abundance in central Kazakhstan in vein and stockwork deposits of Mo-W (Ermilova \& Moleva 1953). It occurs in fractures within unaltered ores immediately below the oxidation zone and rarely within it. It is associated with halloysite, gearksutite, nontronite, limonite, gypsum and sometimes with supergene fluorite, fluellite, ralstonite, chukhrovite and other minerals. Localities include: Akchatay and Karaoba (Ermilova et al. 1960), Eastern Kounrad (Chukhrov 1960), Upper Kayraktin (Stepanov \& Moleva 1962), Bainazar, Nura-Taldy, Seltei (Smol'yaninova 1966), Shelitovoye, Western and others (Ermilova 1963b). Individual localities have their own type of creedite crystals though the causes for this are undetermined (Smol'yaninova 1966).

At Eastern Kounrad (63), creedite and gearksutite formed as supergene minerals following Mo and $\mathrm{W}$ mineralization which was associated with a granite mass (Chukhrov 1960). The presence of pegmatite dykes, greisens, microcline rocks and quartz \pm molybdenite \pm W-bearing veins is typical for this area.

(69) from the oxidation zone of the Upper Cretaceous Dzhaamba (eastern Pamir, USSR) fluorite deposit associated with conglomerates, sandstones, gravels, limestones and argillaceous schists (Khamatova et al. 1970). Coarse concretions of creedite $(25 \times 10 \mathrm{~cm})$ occur impregnated on the surface of iron hydroxides.

(70) at Santa Eulalia, Mexico, where a limestone replacement deposit with $\mathrm{Pb}, \mathrm{Zn}$ and $\mathrm{Ag}$ ores probably formed at high to intermediate temperatures under near-surface conditions (Ridge 1972). In the process of withdrawal from this old mine, ore extraction from the pillars has occasionally revealed pockets of unusual minerals. A moderately large pocket of pinkish purple, well crystallised creedite was found in one pillar. It is often associated with gypsum and galena. The size and morphology of the creedite crystals are similar to the Colquiri locality (Cook, personal communication, 1978).
(71) as white spots on heavily corroded fluorite in a vein cutting silicified chalk at Bergheim, Haut-Rhin, France (Weil et al. 1975). It is accompanied by jarosite, barite and a little galena. The sulphur for this assemblage was provided by the oxidation of pyrite which is locally abundant.

\section{Chukhrovite}

Chukhrovite has been found:

(48) in 1950 in the oxidation zone of the molybdenite-wolframite vein deposit at Karaoba, central Kazakhstan (Ermilova et al. 1960). The Mo-W ores occur in the greisen aureole of alaskites and acidic effusives of Devonian age. Chukhrovite is intimately intergrown with hydrohematite and halloysite, and associated with gearksutite, creedite and supergene REE-rich fluorite. Oxidation of sulphides such as pyrite has dissolved the primary fluorite of the deposit which carries up to $3 \%$ REE.

(57) with yaroslavite in Siberia (Novikova 1973) (see Yaroslavite).

(69) in the oxidation zone of the Dzhaamba fluorite deposit, eastern Pamir (Khamatova et al. 1970) (see Creedite (69)).

\section{Bøggildite}

(1) Bøggildite was discovered in 1950 as salmon pink, columnar aggregates in greisen close to the altered margin of the cryolite deposit at Ivigtut, Greenland (Pauly 1956). Crystals up to $12 \mathrm{~mm}$ in length occur. It is accompanied by sericite, fluorite, albite, quartz, zircon, sphalerite, pyrite and chalcopyrite. This phosphate fluoride may be considered to compositionally lie between tavistockite - $\mathrm{CaCa}_{2} \mathrm{Al}_{2}\left(\mathrm{PO}_{4}\right)_{2}(\mathrm{OH})_{6}$ - and jarlite $\mathrm{NaSr}_{2} \mathrm{Al}_{2}(\mathrm{~F}, \mathrm{OH})_{11}$.

\section{Stenonite}

(1) Stenonite was located at Ivigtut, Greenland, in the contact zone between the siderite-cryolite ore and masses rich in fluorite (Pauly 1962). Cryolite underwent replacement by jarlite, weberite and stenonite. The original sulphides were recrystallised and the siderite partly altered to pyrite and hematite. These processes occurred from and below $200^{\circ} \mathrm{C}$. Stenonite is perhaps better regarded as a carbonate-fluoride than an aluminofluoride. 


\section{Classification of aluminofluoride occurrences}

A) Granitic

B) Carbonatite and silico-carbonatite

C) Volcanic

D) Aqueous environment
Albitised riebeckite granites and other metasomatised granitic rocks.

Alkali granite pegmatites and their fluid inclusions.

Hydrothermal bodies.

Fumarole deposits and metasomatised lavas.

Hot springs.

Volcanic ash fields.

Alkaline lake sediments.

Oxidation zones.

Weathering crusts.

\section{A. Granitic occurrences}

\section{Experimental considerations}

The association of cryolite with granites has been regarded as characteristic for this mineral (Kogarko 1966 1968; Evtyukhina et al. 1967; Stormer \& Carmichael 1970). These authors found by thermodynamic calculations and by experiment that cryolite is stable in $\mathrm{SiO}_{2}$-volatile-rich environments with low $\mathrm{Ca}$, relatively low $\mathrm{Na}$ but high alkali/alumina ratios. With increasing $\mathrm{Ca}$ and $\mathrm{Na}$, the complex anion $\mathrm{AlF}_{6}{ }^{3-}$ dissociates, $\mathrm{Na}-\mathrm{F}$ (villiaumite) and $\mathrm{Ca}-\mathrm{F}$ (fluorite) bonds are developed, and $\mathrm{Al}$ is linked with oxygen. Low silica activity favours villiaumite which is characteristic of agpaitic nepheline syenites.

In fact, cryolite has not yet been synthesised in granitic melts. Experiments in the granite- $\mathrm{H}_{2} \mathrm{O}-\mathrm{HF}$ system at $1000 \mathrm{~kg} / \mathrm{cm}^{2}$ (Glyuk \& Anfilogov 1973) formed topaz crystals in the melts due to reaction between the HF and biotite or feldspars. Much of the $\mathrm{Al}$ and alkalis produced by these reactions was transferred into the coexisting vapour which quenched to give crystals of $\mathrm{Na}_{2} \mathrm{SiF}_{6}, \mathrm{~K}_{2} \mathrm{SiF}_{6}$ and a powdery mixture probably of different fluorides, aluminofluorides and silicofluorides. Similar experiments by Kovalenko (1977) showed that at 0.9-1.7 wt.\% F the coexisting fluid contained $2-2.5 \mathrm{wt} \%$ solids, mainly $\mathrm{SiO}_{2}, \mathrm{Na}_{2} \mathrm{O}, \mathrm{K}_{2} \mathrm{O}$ with minor $\mathrm{Al}_{2} \mathrm{O}_{3}$. It quenched to silicate glass at $800^{\circ} \mathrm{C}$ but $\mathrm{K}$ and $\mathrm{Na}$ fluorides at $600^{\circ} \mathrm{C}$. The $\mathrm{Na}_{2} \mathrm{O} / \mathrm{K}_{2} \mathrm{O}$ ratio increased from 1.2 to 2 during this temperature fall.

Wyllie \& Tuttle (1961) investigated the same system at 2.75 kbar and also recorded white crusts on the walls of quenched capsules. Quartz and different $\mathrm{Na}-\mathrm{Al}$ fluorides, probably hydrated, were tentatively identified. Similar crusts were not significant in $\mathrm{F}$-free runs.

In agreement with these experiments, topaz is occasionally recorded as a magmatic phase in F-rich granites and rhyolites (Kovalenko 1973; Shawe \& Van Alstine 1976, Fig. 10; Eadington \& Nashar 1978) and cryolite is confined to the hydrothermal stage of granite pegmatites or to post-magmatic metasomatised granites.

Fluorine is only weakly partitioned into the vapours coexisting with granite melts, the coefficient being about $0.1-0.2$ at $1 \mathrm{~kb}$ pressure (Hards 1976). Thus, only rarely will F-rich vapours be generated and cool to dense saline hydrothermal solutions. Natural examples appear to be rare but do occur in fluid inclusions in the Volynia pegmatites (Cryolite (4)). The presence of cryolite, elpasolite and fluorite in Volynia inclusions agrees with the mineralogical observations in laboratory experiments. Butuzov et al. (1971) found that when natural feldspar with up to $2.5 \%$ $\mathrm{Na}$ was grown in a F-rich melt, then chiolite developed within fluid inclusions as a captive mineral.

Above $10-12$ wt. $\% \mathrm{~F}$ in the granite- $\mathrm{H}_{2} \mathrm{O}-\mathrm{HF}$ system at $1000 \mathrm{~kg} / \mathrm{cm}^{2}$, the granite melt and the coexisting supercritical hydrous solution coalesce into a supercritical hydrous fluoride melt (Glyuk \& Anfilogov 1973). No crystals appeared in this melt down to the lowest temperature investigated $-575^{\circ} \mathrm{C}$. At lower $\mathrm{F}$ contents the solidus is already reached at $640-740^{\circ} \mathrm{C}$. The Ivigtut cryolite 

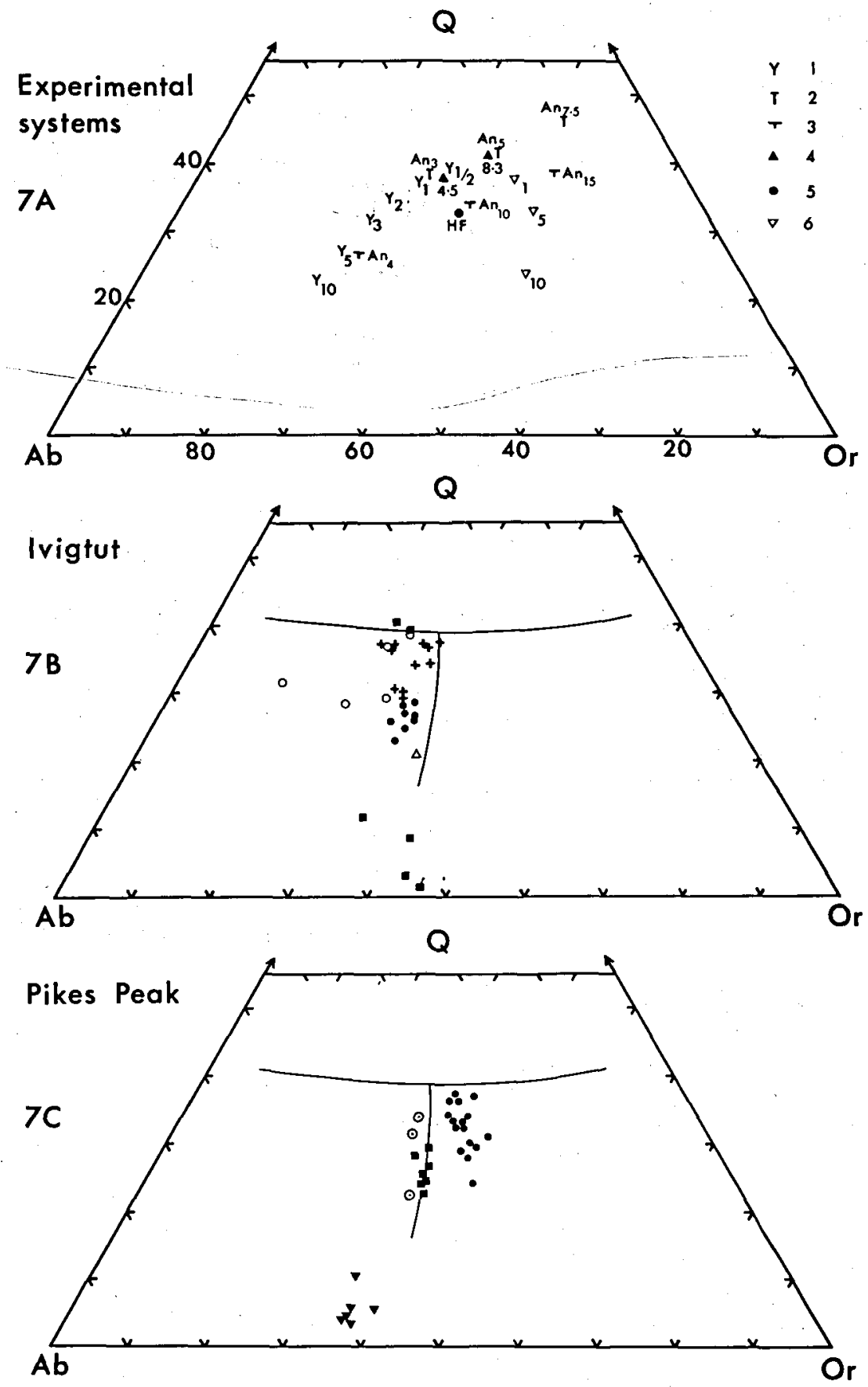

Fig. 7, $Q-A b-O r$ normative diagrams. Where modal descriptions were available, cryolite and fluorite were computed and their components removed prior to calculation of CIPW norms.

7A. Q-Ab-Or diagram for experimentally determined ternary minima. $1-1 / 2,1,2,3,5$ and $10 \mathrm{~kb} P_{\mathrm{H} 2 \mathrm{O}}$, Tuttle \& Bowen $1958 ;$ Luth et al., 1964. Minima in An-bearing systems: 2-1 kb $P_{\mathrm{H} 2 \mathrm{O}}$ James \& Hamilton 1969; 3-7 kb $P_{\mathrm{H} 2 \mathrm{O}}$. Winkler et al. 1975. Minima in Ac and Ns-bearing systems: 4 - Carmichael \& Mackenzie 1963. Minima in HF-bearing system: 5-2 kb with $0.5 \mathrm{~m}$ HF, von Platen 1965. Anhydrous minima: 6-1, 5 and $10 \mathrm{~kb} P_{\text {tot }}$ Luth 1969.

7B. Ivigtut, S. Greenland (Bailey, in preparation). $\square$ trachyte, granophyre dykes; $\bullet$ hornblende biotite leucogranite; + metasomatised leucogranite; o albitised granite; $\triangle$ pegmatite. $Q-A b-O r-A n_{3}$ phase relations at $P_{\mathrm{H} 2 \mathrm{O}}=1 \mathrm{~kb}$ from James \& Hamilton 1969.

7C. Pikes Peak batholith, Colorado (Barker et el. 1975, Fig. 12). • fayalite-free granite; $\square$ fayalite granite; $\bigcirc$ Mount Rósa granite; $\Delta$ quartz syenite. 

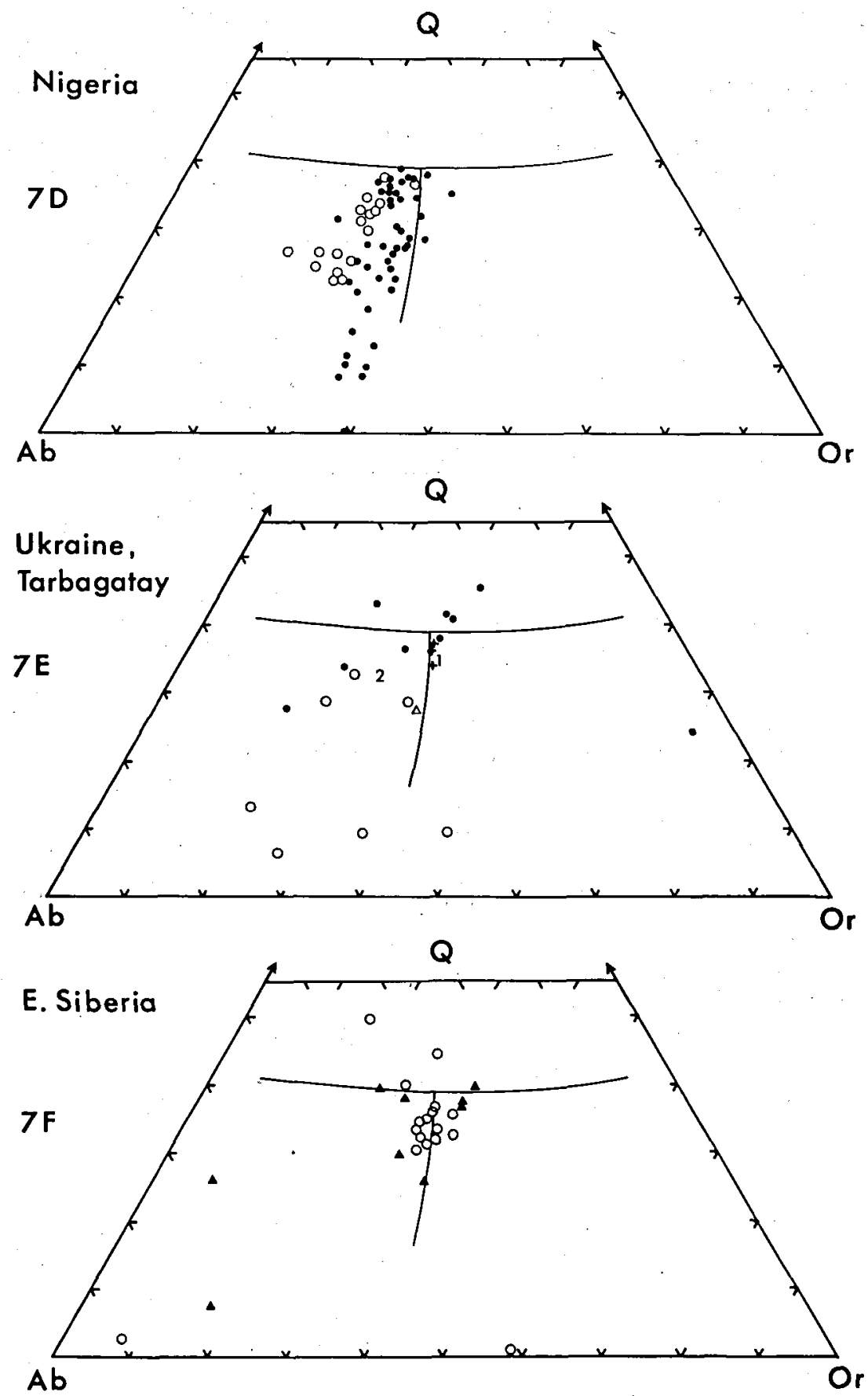

7D. Younger Granites, Nigeria. • granites, quartz syenites, syenites (Freeth 1972, Fig. 1); o Kaffo albite riebeckite granite (Borley et al. 1976).

7E. Ukraine and Tarbagatay granites. • cryolite-bearing Perga granites (Zinchenko 1968; Gurov et al. 1975a); $\triangle$ granite pegmatite, Volyn (Gavrusevich 1932); o albitised pegmatites, Volyn (Kalyuzhnaya et al., 1973); + Large albitised riebeckite granite, Tarbagatay, E. Kazakhstan (Mineev 1968, Table 4); 1 Average alkali granite (Nockolds 1954); 2 Average riebeckite-albite granite (Vlasov 1966, Table 29).

7F. East Siberia metasomatites (Arkhangel'skaya 1968, Table 4; Kudrin 1972, Table 1). A unaltered and slightly altered country rocks; o metasomatites. 
deposit may have initially corresponded to such a hydrous fluoride melt. Its bulk $\mathrm{F}$ content is $\mathbf{1 2 . 9}$ wt.\% (table 2, column 6). Crystallization probably began below $510-590^{\circ} \mathrm{C}$ (Pauly 1960). Characterization of the body as hydrothermal or pegmatitic (i.e. a volatile-rich silicate melt) is probably meaningless at these high $\mathrm{F}$ levels where silicate melts cool and evolve continuously into hydrothermal solutions. Some fluid inclusions in Volynia pegmatites and in rich ore greisens may also be representatives of the transitional silicate-hydrothermal fluids long predicted by granite experimentalists (cf. Bailey 1977, pp. 20-23, 34).

A considerable body of experimental data agrees with the observed phenomenon of $\mathrm{F}$ release and re-concentration in epizonal, residual magma bodies (Bailey 1977). Differential degassing at the magmatic stage releases $\mathrm{CO}_{2}, \mathrm{HCl}$ and $\mathrm{H}_{2} \mathrm{O}$ rather than HF. Small amounts of released $\mathrm{HF}$ are readily resorbed at higher levels in magma columns, especially those rich in alkalis. Crystallization concentrates $\mathrm{F}$ in interstitial melts until saturation is reached when a more intensive degassing begins. Any $\mathrm{F}$ or Na lost, however, is probably resorbed by nearby hotter melts and will delay their completion of crystallization by $36-150^{\circ} \mathrm{C}$ according to different experimentalists. Thus F-rich residual magmas may still exist when other parts of the intrusion are undergoing post-magmatic metasomatism whose initial stages will release more $F$. Emplacement at epizonal levels is critical since at greater depths degassing of $\mathrm{F}$ is restricted while at shallower levels $\mathrm{F}$ escapes more easily from intrusions which themselves become rapidly solidified.

Magmatic granites associated with cryolite The magmatic granites associated with, though not containing, cryolite fall into a well-defined petrologic type. Geologically, they were emplaced in a post-orogenic (platform) or non-orogenic setting, well within continental interiors. Country rocks are typically granites, gneisses or metasediments. Cryolitic granites are late intrusions of major granitic cycles or extensive basic-salic igneous complexes. Regional faulting was prevalent and in some cases controlled the locus and mechanics of emplacement. Intrusions were emplaced at shallow levels in pipes, dykes, stocks, cupolas or sheets and may be as- sociated with comagmatic volcanics. Chilled margins, pegmatites, aplites and hydrothermal veins are common along with porphyritic textures. Contact alteration, where it occurs, is metasomatic rather than thermal. In agreement with this epizonal setting, granite phase relations indicate pressures of $1-2 \mathrm{~kb}$ at the time of formation or re-equilibration of the melts (fig. 7). Ages range from Precambrian to Jurassic with no marked concentration at any particular period.

Chemically, the granite magmas are siliceous, with high alkali and fluorine contents, and distinctly low $\mathrm{Mg}$ and $\mathrm{Ca}$ contents (table 2). Fe-rich mafics are prevalent, e.g. ferruginous biotite, riebeckite, fayalite and siderite, though volumetrically poor. Plagioclases are oligoclase or albite. The high contents of alkalis, large ionic lithophile elements, volatiles and in some cases peralkaline phases (riebeckite, arfvedsonite, astrophyllite, aegirine) define the alkali granite clan. Associated syenites and alkali basalts confirm this status. Peralkalinity indices range from about $0.8-1.1$, generally higher than the value of 0.82 ior average alkali granite (table 2, column 15) (Nockolds 1954). $\mathrm{Na} / \mathrm{K}$ ratios range from $0.65-0.82$, significantly higher than 0.61 for the average alkali granite. The cryolitic granites may thus be assigned to a sodic group within the alkali granite clan.

The high $\mathrm{Na} / \mathrm{K}$ ratios are reflected in the normative $A b / O r$ ratios (fig. 7). Increases in normative anorthite, or acmite plus sodium silicate, displace minimum melts and the two-feldspar thermal valley towards lower $\mathrm{Ab} / \mathrm{Or}$ ratios on the $\mathrm{Q}-\mathrm{Ab}-\mathrm{Or}$ triangle; these features are absent. $\mathrm{High} \mathrm{Ab} / \mathrm{Or}$ ratios are also consistent with water vapour pressures equalling or approaching the total pressure and this agrees with the presence of hydrous phases and post-magmatic alteration.

$F$ contents of the magmatic granites are distinctly high $(0.3-0.8 \%)$. Typical alkali granites contain $0.1-0.2 \%$ and calcalkaline granites generally less than or about $0.1 \% \mathrm{~F}$ (Bailey 1977).

The genesis of magma series which eventually gave rise to cryolite-bearing granitic materials has been variously explained. Barker et al. (1975) emphasised the association of alkali granites with gabbros, anorthosites and syenites. They recognise this association in three cryolite-bearing regions: the Pikes Peak batholith, the Younger Granites of Nigeria and the Gardar province; the 
Korostensky complex, Ukraine, may also be added. Barker et al. (1975) proposed a model for the Pikes Peak batholith in which alkali basalt magma reacts with granulite facies lower crust to produce the quartz syenite parent for the sodic series, and this liquid in turn reacts with amphibolite facies intermediate crust to produce the main granite series of the batholith. Bowden \& Turner (1974) also invoke crustal melting by basic magmas to generate the Younger Granites of Nigeria, though this viewpoint was not accepted by Eborall \& Wright (1974).

In the Gardar province of $S$. Greenland, the low initial ${ }^{87} \mathrm{Sr} /{ }^{86} \mathrm{Sr}$ ratios of the salitic intrusives (including the Ivigtut granite) suggest that crustal processes were unimportant in their formation and that fractional crystallization of mantle-derived basaltic magmas was a more plausible mechanism (Upton 1974; Blaxland 1976). In this model, $\mathrm{Na} / \mathrm{K}$ ratios are controlled by melting and fractionation processes in the mantle. Consistent with the fractionation model is the trend of quartz syenites and alkali granites, and volcanic equivalents, along the two-feldspar thermal valley in $\mathrm{Q}-\mathrm{Ab}-$ Or diagrams (fig. 7).

In the Mongol-Tuva province, which embraces the Erzin massif (Cryolite (10)), Pavlenko (1974) suggested that the granitic and alkaline rocks were developed by palingenesis of sialic crust with later modifications due to metasomatism.
Cryolitic metasomatic granites and hydrothermal veins

Post-magmatic alteration of alkali granites is a widespread and critical process in the appearance of cryolite. Cryolitic pegmatites show analogous alterations.

Zarayskiy \& Zyryanov (1973) studied the open-system interaction. (diffusive metasomatism) of fluoride solutions of $\mathrm{Na}$ and $\mathrm{K}$ on biotite and riebeckite granite at $500-600^{\circ} \mathrm{C}$ and $1 \mathrm{~kb}$ pressure for 96 hours. Elpasolite (30-75 vol.\%) was widely developed following attack by $\mathrm{K}$ - or K-Na fluoride solutions but no aluminofluorides appeared after reaction with $\mathrm{Na}$ fluoride solutions. Instead, F was taken up by alkali amphiboles, biotite and fluorite.

Table 4 gives a simplified scheme of post-magmatic metasomatism. During stage 1 , and to some extent stage 2, leaching of many elements, including $\mathrm{F}$, takes place and these are added to elements already in the residual fluids responsible for the metasomatism. Elements are mainly leached from micas, amphiboles and calcic plagioclase. F probably combines with various elements to form complex ions with alkaline properties, e.g. $\mathrm{Sn}(\mathrm{OH}, \mathrm{F})_{6}{ }^{2-}, \mathrm{KBeF}_{3}, \mathrm{NaAlF}_{4}$ (Shcherba 1970).

With falling temperature, pressure and $\mathrm{pH}$, the early fluoriferous complexes decompose and $\mathrm{F}$ is released into vapours or hydrothermal solutions,

Table 4. Simplified scheme of post-magmatic alteration of granites related to cryolite occurrences (based on Beus et al. 1962, Mineev 1968, Kudrin \& Kudrina 1968, Bailey in preparation).

\begin{tabular}{llll}
\hline Stage & Precipitation of & Mobilization of & Approximate pH \\
\hline I Microclinization & $\mathrm{K}, \mathrm{Rb}$ & $\mathrm{Na}, \mathrm{Si}, \mathrm{Li}, \mathrm{Al}, \mathrm{F}, \mathrm{Fe}$ & $9-8$ \\
2 Albitization & $\mathrm{Na}, \mathrm{Fe},(\mathrm{F})$, & $\mathrm{Si}, \mathrm{Li}, \mathrm{Al}, \mathrm{K}, \mathrm{F})$ & $8-6$ \\
& $\mathrm{Ga}, \mathrm{W}, \mathrm{Zr}, \mathrm{Nb}, \mathrm{REE}$ & & $6-4$ \\
3 Greisenization & $\mathrm{F}, \mathrm{Si}, \mathrm{K}, \mathrm{Al}, \mathrm{Li}$ & $\mathrm{Na}$ & $6-8$ \\
& $\mathrm{Sn}, \mathrm{Mo}, \mathrm{Zr}, \mathrm{Be}$ & & \\
4 Late olbitization & $\mathrm{Na}$ & $\mathrm{K}$ & \\
5 Late microclinization & $\mathrm{K}$ & -
\end{tabular}

At Ivigtut and Erzin, greisenization may be divided into early mica formation and late formation of quartz,

fluorite and sulphides. Stages 4 and 5 are of minor importance. 
or is precipitated as cryolite, fluorite, muscovite, Li-micas, gagarinite or pyrochlore. Some F is precipitated during albitization in riebeckite, but the bulk of $\mathrm{F}$ held in albitised cryolitised granites was probably precipitated at the close of albitization (Ivigtut; Nigeria, Erzin). Kalyuzhny \& Gigashvili (1972), however, consider that cryolite (and fluorite and topaz) crystallised contemporaneously with albite in the most acid stage of alteration ( $\mathrm{pH} 6.5-4.2)$ of the Volyn pegmatites. In the Q-Ab-Or diagrams (fig. 7), albitised granites and pegmatites generally plot in a field extending from the parent granite towards the $\mathrm{Ab}$ corner.

Cryolite at Ivigtut and Perga, as well as cryolite II at Erzin, also appears after the stage of greisenization. At Erzin, cryolite I was unstable during greisenization and in general this Na-poor environment should be unfavourable for cryolite development. Greisenization releases large masses of $\mathrm{Na}$, due to muscovitization of feldspars, and this $\mathrm{Na}$ is available for combination with $\mathrm{F}$ at the subsequent sodic stage. Fluorine, meanwhile, is extensively precipitated at the greisen stage in micas, fluorite, topaz etc. and only in exceptional circumstances will excess $F$ pass into the late sodic stage and form cryolite. Such abnormal conditions must have prevailed at Ivigtut where several million tons of cryolite crystallised in the unique cryolite deposit after metasomatic activity had ceased.

The $\mathrm{P}-\mathrm{T}-\mathrm{pH}$ conditions of the later metasomatic (i.e. diffuse) stages (stages 3-5) overlap those of hydrothermal veining activity. It is not uncommon for accessory disseminations of cryolite, as well as aggregates, stringers and veins of cryolite, to be present in a single host rock. Cryolite-bearing hydrothermal veins are recorded from Ivigtut, Perga, Erzin, Nigeria and Tarbagatay. The typical Ivigtut vein assemblage of cryolite, quartz, siderite and sulphides is also found at Perga and Erzin.

Spatial separation of the metasomatic stages is limited within pegmatite bodies and no longer occurs when post-magmatic fluids become isolated as minute fluid inclusions. The non-dispersion of the late F-rich fluids of cryolitic alkali granite pegmatites often leads to the metre-sized development of aluminofluoride masses, mainly cryolite but also with large crystals of chiolite and cryolithionite. The aluminofluorides were formed after albitization in the Ivigtut and Miask pegmatites but contemporaneously with albitization in the Mount Rosa and Volyn pegmatites.

Some of the Volyn inclusions have trapped and preserved the crystallization history of hydrous F-rich solutions on a microscopic scale and show that these cool to multi-phase inclusions with a vapour bubble, a dilute solution and a high percentage of daughter crystals including cryolite, elpasolite and fluorite.

The Ivigtut cryolite deposit also represents an originally homogenous and dominantly isolated body, possibly of hydrous fluoridic "melt", which subsequently underwent a complex, closed-system crystallization history. The massive nature of the cryolite and the poverty of hydrous phases, aqueous growth textures and voids in the deposit all point to exceptionally low water contents in this parental melt. Immiscible drops of an Fe-rich carbonate-sulphide "melt" may have been distributed throughout the original fluoridic melt (Karup-Møller \& Pauly, in press). After crystallization of the early large units of quartz and siderite-cryolite, residual melt pockets in the latter cooled to a pure cryolite mass and to a Th-REE-Sr-rich fluorite-black cryolite mass. Later fluorite-, muscovite- and topaz-rich zones demonstrate aqueous replacement and growth textures (i.e. a build-up of $\mathrm{H}_{2} \mathrm{O}$ at this stage), exhaustion of $\mathrm{Na}$ before $\mathrm{F}$, temperatures of $200-300^{\circ} \mathrm{C}$ and mobilization of earlier sulphide assemblages. At even lower temperatures, hydrated aluminofluorides, baryto-celestite and other rare minerals appeared and finally local kaolin formation took place.

\section{Other aluminofluorides}

The formation conditions of the other aluminofluorides at cryolite localities are inadequately studied. Simpson (1920) generalised that the anhydrous alkali aluminofluorides were followed by hydrous varieties and then basic hydrous gearksutite. In fact, anhydrous elpasolite forms later than pachnolite at Pikes Peak, and replaces prosopite at Perga. At Ivigtut and Miask, cryolite, cryolithionite and chiolite - all anhydrous - did form early in the aluminofluoride history. The sequence of later $\mathrm{OH}-$ and $\mathrm{H}_{2} \mathrm{O}$-bearing aluminofluorides is highly varied; two or more generations or habits may be present. Some probably formed by alteration of the earlier 
aluminofluorides, whereas others crystallised as overgrowths or primary phases from hydrothermal solutions (prosopite at Perga). Gearksutite develops as earthy masses filling closed voids or as a supergene weathering crust.

The anhydrous formation of chiolite, cryolithionite and weberite has been studied (Holm 1963; Stinton \& Brown 1975; Craig et al. 1978) but these experiments are hardly relevant to natural environments. Reproduction under hydrous conditions of individual minerals and alteration processes at cryolite localities, combined with an assessment of fluid inclusion data, is required.

\section{Lake Khanka and East Siberia}

The cryolite occurrences at Lake Khanka and East Siberia are less directly related to the autometasomatism of parent granites. The metasomatised limestone xenoliths at Lake Khanka provide clear evidence that cryolite may form in Ca-rich environments; analogies with carbonatite localities might be suggested. Na activity was atypically high during greisenization of the xenoliths."

The East Siberian metasomatites developed at temperatures just below the formation of granite melts and melts in fact may be present at no great depth. Significantly, Kovalenko (1977) reported that in the presence of $\mathrm{H}_{2} \mathrm{O}$ and $\mathrm{HF}$ at $1000 \mathrm{~atm}$. the onset of melting in a granite involves considerable loss of alkalies, particularly sodium, to the coexisting fluid. The amount of $\mathrm{Na}_{2} \mathrm{O}$ entering the fluid increases from 0.7 to $1.6 \mathrm{wt} \%$ as $\mathrm{F}$ contents increase from 0.83 to $1.67 \mathrm{wt} . \%$. The high $\mathrm{Na}, \mathrm{Fe}$ and $\mathrm{F}$ activity of the $\mathrm{E}$. Siberian metasomatising fluids, and the low Ca contents of the rocks, indicate that formation of cryolite and the other aluminofluorides followed a very similar pattern to that in albitised riebeckite granites (Kudrin 1972).

\section{Cryolite-fluorite competition}

The competition for $F$ between cryolite and fluorite in various cryolite-bearing series has been followed using a $\mathrm{Ca}-\mathrm{Na} / 10-\mathrm{F}$ triangle (fig. 8). During magmatic differentiation there is a trend of increasing $\mathrm{Na} / \mathrm{Ca}$ and $\mathrm{F} / \mathrm{Ca}$ ratios. This trend continues into the autometasomatic derivatives and their cryolite-bearing varieties which approach the position of pure cryolite in the triangle. The appearance of cryolite is thus consistent with the chemical evolution of highly fractionated alkali leucogranites, especially their metasomatic derivatives.

The Ivigtut granitic rocks are notable for attaining the highest $\mathrm{Na} / \mathrm{Ca}$ ratios and $\mathrm{F}$ contents. The cryolite deposit is more calcic than many of the associated metasomatites due to the significant presence of fluorite.

Although fig. 8 emphasises that an evolutionary path exists from magmas to cryolite-bearing derivatives, it should be noted that most of the localities considered also contain paths which approach the composition of fluorite on the triangle, e.g. Na-poor, fluorite-bearing Ivigtut greisens. The critical condition is that fluorite development is kept to a minimum in these generally Ca-poor systems, and that excess $\mathrm{F}$ and $\mathrm{Na}$ are available to locally form cryolite.

\section{Tin granites: a comparison}

The worldwide "tin" granites are also typically epizonal leucogranites with high F-Li-Rb contents and well developed autometasomatism (Klominsky \& Groves 1970; Tischendorf 1973) (table 2, column 20). However, they are virtually restricted to the Phanerozoic and are usually more intimately related to orogenic structures and magmatism. They have calc-alkaline affinities with higher $\mathrm{Ca}$ and $\mathrm{Mg}$ but lower Na contents. The average $\mathrm{Na} / \mathrm{K}$ ratio and peralkalinity index are low -0.59 and 0.76 , respectively. Characteristic accessories are muscovite, topaz, fluorite and cassiterite. Sn and $B$ contents are probably higher. Greisenization and hydrothermal alteration (kaolins) seem more dominant than albitization.

\section{B. Carbonatite and silico-carbonatite}

Carbonatites are dominantly composed of carbonates of $\mathrm{Ca}$ and $\mathrm{Mg}$, occasionally $\mathrm{Fe}, \mathrm{Mn}$ or $\mathrm{Na}$. Silicates (feldspar, pyroxene etc.) and accessories may also be present. The main F-bearing phases, generally in minor or accessory amounts, are fluorite, fluor apatite, pyrochlore, bastnäsite and phlogopite. Whole-rock F levels are normally of the order of $0.05-0.3$ wt.\%. Experimental evidence confirms the ability of apatite and fluorite 


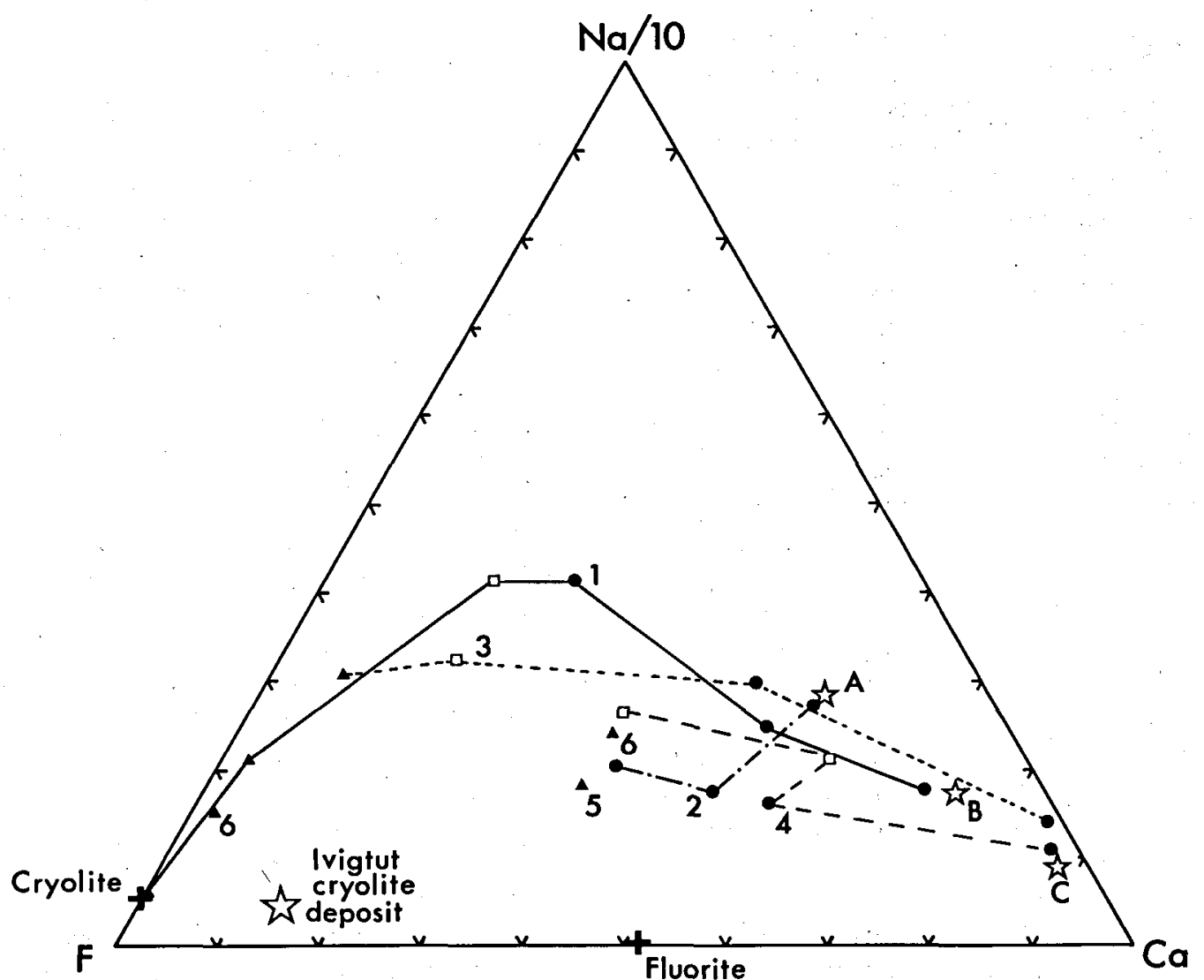

Fig. 8. Ca-Na/10 - F relations of cryolite-bearing granitic series. 1 Ivigtut, 2 Pikes Peak sodic series, 3 Nigerian Younger Granites, 4 N.W. Tarbagatay, 5 Perga granite, 6 E. Siberia (see text for sources of data). Granites are divided into magmatic (circles), metasomatic (squares) and cryolite-bearing metasomatic (triangles). Stars - average alkali granite $(A)$, granite $(B)$ and granodiorite $(C)(N o c k o l d s$ 1954; F from Bailey 1977).

to crystallise from F-bearing carbonatitic systems (Wyllie 1966).

In carbonatites from Africa and India, late-stage hydrothermal quartz-fluorite deposits occur (Deans 1966; Deans et al. 1972). Fractionation in the Jacupiringa carbonatite, Brazil, yielded a rest fluid rich in $F$ and produced small veinlets of apatite, magnetite and sulphides (Melcher 1966). Fenitised country rocks near carbonatite complexes generally show only slight increases in the levels of $F$ which is held in amphiboles and fluorite. The main added components are usually $\mathrm{Na}$ and $\mathrm{Fe}$. However, at Alnö in Sweden some fenitised wallrocks contain 20-25\% fluorite (von Eckermann 1948).

Three outstanding examples of carbonatitic magmas rich in $\mathrm{Na}$ are also rich in $\mathrm{F}$. Two of them carry cryolite.

(1) The Oldoinyo Lengai volcano of Tanzania recently erupted lavas of $\mathrm{Na}-\mathrm{K}$ carbonate with high levels of $\mathrm{F}$ (1.84 and $2.69 \%$ in two analyses). The groundmass contains minute crystals of fluorite (Dawson 1966). A study of the $\mathrm{Na}_{2} \mathrm{CO}_{3}-\mathrm{K}_{2} \mathrm{CO}_{3}-\mathrm{CaCO}_{3}$ system lead Cooper et al. (1975) to suggest that these lavas probably separated immiscibly from nephelinitic magma. These authors consider that alkali carbonatite liquids only develop when the activity of silica is too low for silicate formation and the magma is dry. In the normally wet carbonatites, alkalis not held by silicates will be lost in a hydrous fluid phase and may cause fenitization.

(2) The silico-carbonatite sill at Francon quarry, Montreal (see Cryolite (15)) averages $9 \% \mathrm{Na}_{2} \mathrm{O}$ and $0.3 \%$ F. Cryolite and fluorite crystallised from cavities in related sills of this quarry. Jambor et al. (1976) consider that the Francon sill initially consisted of albite and anal- 
cime phenocrysts in a $\mathrm{K}$-rich melt highly charged with $\mathrm{Na}, \mathrm{CO}_{3}$ and $\mathrm{H}_{2} \mathrm{O}$. On cooling, at least part of the volatiles were trapped and reacted with the silicates to form the abundant dawsonite. Dawsonite is thought to be a primary autohydrothermal mineral precipitated from the residual volatiles. Lower temperature hydrothermal solutions, it appears, were locally enriched in fluorine and produced cryolite-bearing assemblages in some cavities.

(3) The Goldie carbonatite, Colorado, evolved to produce late fluids rich in $\mathrm{Na}$ and $\mathrm{F}$ which reacted with the primary calcite to yield cryolite and other aluminofluorides (see Cryolite (14)).

\section{Volcanic occurrences}

The HF contents of volcanic gases and fumarole condensates are normally about $10-300 \mathrm{ppm}$ whereas most volcanic hot springs only contain $F$ levels of 0.1-12 ppm (White \& Waring 1963; Sugiura et al. 1963; Mahon 1964). HF, however, commonly forms about $0.1-3 \mathrm{wt}$.\% of the "active" volcanic gases and is one of the most reactive gaseous species. HF concentrations rose to $21 \mathrm{wt} . \%$ of the active gases in exhalations from the Valley of Ten Thousand Smokes, Alaska. Also acid spring waters near active volcanoes may contain up to $0.5-0.6 \mathrm{wt} . \% \mathrm{~F}$, the $\mathrm{F}$ being derived from volcanic steam which itself can give rise to condensates with $2 \% \mathrm{~F}$ (Mahon 1964; Roberson \& Barnes 1978).

Much of the gaseous fluorine from volcanoes is dispersed into the atmosphere and surface runoff, but some is concentrated in fumarole deposits and metasomatised lavas. Fluorite is probably the most common fluoride of fumarole deposits, though a number of rare fluoride species, e.g. the silicofluorides malladrite and hierarite and the fluoborates avogadrite and ferruccite which are confined to this environment, are occasionally found. Among the aluminofluorides, ralstonite is quite widely distributed whereas elpasolite and weberite are only known from single localities; suggested cryolite and thomsenolite occurrences on Tristan da Cunha need to be confirmed.

The presence of silicofluorides and aluminofluorides among the exhaled products of volcanoes is in agreement with their presence in the vapour phase and quenched crusts of experiments in the granite- $\mathrm{H}_{2} \mathrm{O}-\mathrm{HF}$ system (Wyllie \& Tuttle 1961; Glyuk \& Anfilogov 1973).

Stoiber \& Rose (1974) described a generalised zoning pattern for incrustations around fumaroles (fig. 9). Fluorite and cryptohalite $\left(\left(\mathrm{NH}_{4}\right)_{2} \mathrm{SiF}_{6}\right)$ are assigned to zone $\mathrm{C}\left(150-250^{\circ} \mathrm{C}, \mathrm{pO}_{2}\right.$ $\left.10^{-11}-10^{-5}\right)$ and ralstonite to zone $\mathrm{E}\left(<100^{\circ} \mathrm{C}\right.$, $\mathrm{pO}_{2} 10^{-7}-1$ ). Within the fumarole vent, zone $\mathrm{A}$ at $400-900^{\circ} \mathrm{C}$ is characterised by $\mathrm{pO}_{2} 10^{15}-10^{-5}$, low $\mathrm{Cl} / \mathrm{SO}_{4}$ ratios and the presence of thenardite $\left(\mathrm{Na}_{2} \mathrm{SO}_{4}\right)$.

If fumarole gases and minerals were in equilibrium at $500^{\circ} \mathrm{K}$ (zone $\mathrm{C}$ ), then sulphates would be likely stable phases. The presence of $\mathrm{NaCl}, \mathrm{KCl}$ and $\mathrm{CaF}_{2}$ probably reflects the quenching of the sulphur gases, while the haloid gases $(\mathrm{HCl}, \mathrm{HF})$ remain active and in equilibrium. In lower temperature zones, e.g. zone $\mathrm{E}$, dilute $\mathrm{H}_{2} \mathrm{SO}_{4}$ liquid aerosols coat the wallrock and cause acid alteration with formation of sulphur and gypsum. Hydrated and hydroxyl-bearing compounds, such as ralstonite, also become stable, and probably result from halogen acid alteration of the wallrock.

Similar low temperatures of formation were assigned to ralstonite-bearing HF metasomatised basalts $\left(200-300^{\circ} \mathrm{C}\right)$ and fumarole deposits $\left(98-170^{\circ} \mathrm{C}\right.$ ) of Kamchatka (Naboko 1959b).

For Hawaiian volcanoes, Naughton et al. (1976) pointed out that F-rich incrustations were

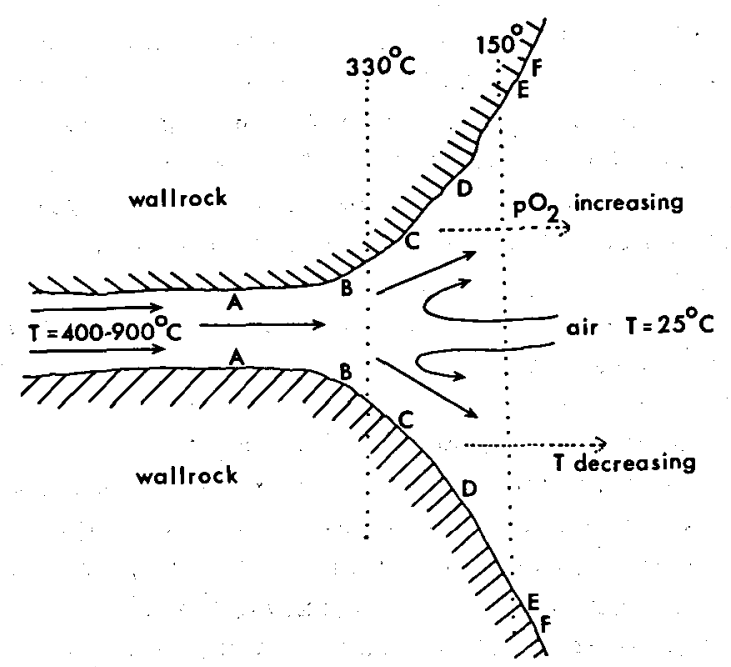

Fig. 9. Schematic section of a fumarole showing incrustation zones A to F. Fluorine minerals characterise zones $C$ (fluorite, cryptohalite) and E (ralstonite). Redrawn after Stoiber \& Rose (1974, Fig. 2). 
only observed in a few cases where fumarolic emission was strong enough to exclude air. A single high temperature reduced condensate contained $21.25 \mathrm{wt} . \% \mathrm{~F}$ (on a water-free basis) whereas eight high temperature oxidised condensates averaged only 0.97 wt. $\% \mathrm{~F}$. This contrast was in semi-quantitative agreement with compositions, computed under the assumption of thermodynamic equilibrium at $827^{\circ} \mathrm{C}$, for condensates in reduced (13.40 wt.\% F) and oxidised ( 2.24 wt.\% F) environments. Below $300^{\circ} \mathrm{C}$, water soluble condensates are dominated by sulphates; $\mathrm{F}$ contents only range from $0.007-0.113 \mathrm{wt}$.\%.

Incrustations collected from drill holes in Hawaiian lava lakes contained $0.007-43.93$ wt. $\%$ $F$, the amount increasing in the more reduced samples. Ralstonite was identified in these incrustations and also from F-metasomatised basalt scraped from the walls of the drill holes. Experimental interaction of vapour from an aqueous solution of $\mathrm{HF}(48 \%)$ with tholeiitic basalt at $140^{\circ} \mathrm{C}$ yielded mainly ralstonite in the dry reaction product.

The absence of ralstonite from the high temperature inner zones of fumaroles is supported by the experiments of Di Girolamo \& Franco (1968) who found that ralstonite was transformed to topaz at $750^{\circ} \mathrm{C}$ and to mullite at higher temperatures.

It should be emphasised that $\mathrm{HCl}$ contents of volcanic gases and deposits are nearly always greater than those of HF. Only locally do -fluorides play a more active role as at certain volcanoes in Kamchatka.

Volcanic steam, hot springs and the surface runoff of volcanoes form a link between the volcanic and aqueous environments and are considered on p. 35.

\section{Aqueous environments}

Rock-, and mineral-water interaction

There is experimental and natural evidence that aluminofluorides, particularly the hydrated varieties, may develop by the interaction of aqueous solutions with rocks and minerals, the fluorine being supplied by any of these materials.

During the interaction of $\mathrm{F}^{-}$-bearing solutions with clay minerals, alumina hydrates and allophane, large amounts of $\mathrm{F}$ are taken up. Up to
$50 \%$ of the $\mathrm{OH}^{-}$ions may be replaced, the amount increasing with temperature. Evidence exists that the $\mathrm{F}$ : (a) replaces $\mathrm{OH}$ in the lattices, (b) breaks up the clay structure and releases $\mathrm{OH}^{-}$ and $\mathrm{Al}^{3+}$ into solution where cryolite and $\mathrm{K}_{3} \mathrm{AlF}_{6}$ may be formed in highly fluorinated products or (c) is loosely adsorbed. In alumina hydrates diaspore and gibbsite - hydrogen bonding appears to strongly inhibit exchange (Romo \& Roy 1957; Birrell 1961; Huang \& Jackson 1965; Semmens \& Meggy 1966). Only intense fluorination leads to the substitution of $\mathrm{O}^{2-}$ ions by $\mathrm{F}^{-}$ ions and the breaking of Al-O-Si oxygen bridges with formation of a silicofluoride (Fijal \& Tokarz 1975). F adsorption at low, i.e. normal, concentrations (2-16 ppm) may be largely by exchange with $\mathrm{OH}$ of $\mathrm{Al}(\mathrm{OH})_{3}$, rather than with crystal lattice $\mathrm{OH}$ of clay minerals (Bower \& Hatcher 1967).

In experiments designed to investigate hydrothermal alteration, Leonard (1927) reacted feldspars with $\mathrm{Al}_{2} \mathrm{~F}_{6}$ and $\mathrm{Na}_{2} \mathrm{SiF}_{6}$ in the presence of water vapour at $350^{\circ} \mathrm{C}$ and 1 atmosphere. Silica and cryolite were obtained. Reaction of only $\mathrm{Al}_{2} \mathrm{~F}_{6}$ and $\mathrm{Na}_{2} \mathrm{SiF}_{6}$ under these $\mathrm{P}-\mathrm{T}$ conditions failed to produce cryolite. With the same fluorides, cryolite also developed at $400^{\circ} \mathrm{C}(8$ atmos.) and $575^{\circ} \mathrm{C}$ (10 atmos.) from microcline. Leonard concluded that a hydrothermal (or perhaps hypothermal) origin can be assigned to cryolite.

Michel-Lévy \& Wyart (1948) found that during interaction of $\mathrm{Na}_{2} \mathrm{SiF}_{6}+\mathrm{Al}_{2} \mathrm{O}_{3}+\mathrm{SnCl}_{2}+$ $\mathrm{H}_{2} \mathrm{O}$ with sandstone at $500^{\circ} \mathrm{C}$ and about 4000 $\mathrm{kg} / \mathrm{cm}^{2}$ chiolite formed in preference to cryolite when more $\mathrm{Al}_{2} \mathrm{O}_{3}$ was used. Quartz and topaz also developed.

Emel'yanova \& Zigareva (1960) reacted an aqueous solution of $\mathrm{H}_{3} \mathrm{BO}_{3}$ (about $14 \%$ ) and $\mathrm{NaCl}$ or $\mathrm{NaF}$ (about $3 \%$ ) with topaz, pyrophyllite, or kaolinite, and the oxides of the elements in tourmaline at $350-600^{\circ} \mathrm{C}$ and $400-3000$ atmos. to produce tourmaline, fayalite, chiolite, nepheline and ralstonite. Similar experiments by Voskrenskaya (1976) formed cryolite, cryolithionite, weberite and elpasolite.

Beryl is unstable in $\mathrm{Al}^{3+}-\mathrm{F}^{-}$-carbonate solutions breaking down to aluminofluoride minerals or, at low F activity, to aluminosilicate minerals (Klyakhin \& Lebedev 1974).

Low-temperature $\left(40^{\circ} \mathrm{C}\right)$ laboratory digestion 
of shales with hydrofluoric acid forms ralstonite, $\mathrm{K}_{2} \mathrm{SiF}_{6}, \mathrm{Al}_{2} \mathrm{OF}_{4} .3 \mathrm{H}_{2} \mathrm{O}$ and $\mathrm{K}_{3} \mathrm{AlF}_{6}$ (Hitchon et al. 1976). Kukovskii (1962) treated the palygorskite of a bentonite deposit with HF for 48 hours to yield hydrous $\mathrm{Mg}$ and $\mathrm{Al}$ fluorides, fluellite and ralstonite.

Most of the above experiments were undertaken with F-rich solutions or acids. Table 5 shows that river, sea and groundwater have very low F (and Al) contents. Samples of South African groundwater from alkalic rocks ranged from 0.7-35.1 ppm (average $8.7 \mathrm{ppm}$ ) compared with values of 0-9.0 ppm in all other samples (average about $0.2 \mathrm{ppm}$ ) (Bond 1946).

Thermal springs and hot waters obtained by drilling hydrothermal areas tend to have higher levels of $\mathrm{F}$ and $\mathrm{Al}$ but the dominant $\mathrm{F}$ phase of precipitates is always fluorite (White 1957) (table 5, analyses 4-6). A notable exception is at the Hortense Hot Spring, Colorado (Sharp 1970; Pabst \& Sharp 1973) where sublimates of opal and kogarkoite $\left(\mathrm{Na}_{2} \mathrm{SO}_{4} \cdot \mathrm{NaF}\right)$ have formed. Aluminofluorides (creedite and gearksutite) were developed at Wagon Wheel Gap, Colorado, and Hot Springs, Virginia, by reaction between large volumes of underground thermal waters and aluminosilicate (rhyolite, clay) materials.

High $F$ levels were found in the early surface runoff following the 1947-1948 eruption of Mt. Hekla, Iceland (Stefánsson \& Sigurjánsson 1957). $6-35 \mathrm{mg}$ of fluoride could be extracted from $100 \mathrm{gm}$ of the Hekla ash. Thus groundwaters may leach $F$ loosely held on the surface of fine grained particles and react with porous ash layers.

Table 5. Contents of $F$ and other ions in natural waters (in ppm).

\begin{tabular}{|c|c|c|c|c|c|c|c|}
\hline & $\therefore \mathrm{Na}^{+}$ & $\mathrm{Al}^{3+}$ & $F^{-}$ & $\mathrm{HCO}_{3}^{-}$ & $\mathrm{SO}_{4}{ }^{2-}$ & $\mathrm{Cl}^{-}$ & $\mathrm{Ca}^{2+}$ \\
\hline 1 & 6.3 & 0.2 & 0.15 & 58.4 & 11.2 & 7.8 & 15 \\
\hline 2 & 10760 & 0.001 & 1.3 & 142 & 2712 & 19353 & 411 \\
\hline 3 & 35 & 0.04 & 0.2 & 215 & 36 & 16 & 50 \\
\hline 4 & 815 & - & 7.2 & 177 & 53 & 1255 & 24 \\
\hline 5 & : 94 & 0.40 & 13 & 44 & 101. & 9.5 & 3.4 \\
\hline 6 & 477 & 0.35 & 6.8 & 1020 & 169 & 206 & 67 \\
\hline 7 & 44.5 & - & 0.4 & 227 & 120.5 & 18 & 61.4 \\
\hline 8 & 130000 & - & 1500 & $110000^{* 1}$ & 2300 & 85000 & $0.015^{* 2}$ \\
\hline 9 & 99650 & - & 77 & 9000 & 47350 & 161000 & 3.5 \\
\hline 10 & 108100 & - & 13 & $17400^{\infty 1}$ & 40200 & 130200 & n.f. \\
\hline 11 & 23230 & $\sim 1000$ & 12500 & $2314^{* 1}$ & n.f. & 70 & n.f. \\
\hline
\end{tabular}

*1 Total carbonates, $\$ 2$ Estimated from absence of fluorite at $20^{\circ} \mathrm{C}$, n.f. not found

1 River water, median world values (Livingstone 1963).

2 Seawater (Turekion 1969).

3 Groundwater, average (Davis \& DeWiest 1966).

4 Volcanic hot springs, average of five (White 1957).

5 Hortense Hot Spring, Colorado (Sharp 1970).

6 Wagon Wheel Gap Hot Spring, Colorado (Hem, personal communication, 1977).

7 Postulated source water for Green River Formation (Wolfbaver 1971).

8 Final saturated brine, Lake Magadi, Kenya (Eugster 1970, Table 2).

9 Interstitial brine in mud, Deep Springs Lake, California (Jones 1965).

10 Brine from 5 feet depth, core HH, Upper Salt, Searles Lake, California (Smith 1979, Table 16).

11 Deep mine water, sample 119, Lovozero, U.S.S.R. (Kroynov et al. 1969). 
This is the process suggested by Bernauer (1941) to explain the formation of gearksutite at Vulcano, Italy.

Volcanic hot springs and groundwaters are the natural successors to the higher temperature fumarole deposits where ralstonite is widely reported.

\section{Alkaline lake sediments}

F-rich brines develop in Ca-poor alkaline lakes following a complex history of evaporation. Most salt lakes rich in $\mathrm{Ca}^{2+}, \mathrm{Cl}^{-}$and $\mathrm{CO}_{3}{ }^{2-}$ or with $\mathrm{NO}_{3}{ }^{2-}$ or $\mathrm{BO}_{3}{ }^{-}$do not concentrate $\mathrm{F}$ during evaporation and it is probably removed by fluorite, clay minerals and biota.

The alkaline waters of Lake Magadi, Kenya, are considered to be modern equivalents to the parent lake for the Green River Formation (see Cryolite (16)) (Eugster 1970; Jones et al. 1977). Lake Magadi is sited in an area of active alkaline and carbonatitic volcanism and block-faulting. The hydrology is characterised by an extensive inflow of stream water and high evaporation rates in a closed basin. The $F$ levels of feeder rivers are not notably high (0.1-1.9 ppm) and only a little $F$ is removed by early fluorite precipitation. $\mathrm{F}$ increases significantly through evaporative concentration because $\mathrm{CaF}_{2}$ precipitation is avoided following the removal of $\mathrm{Ca}$ by calcite and dolomite. F levels rise rapidly until villiaumite $(\mathrm{NaF})$ saturation is reached shortly after trona begins to crystallise. Concentration is less rapid thereafter but rises to about $1500 \mathrm{ppm}$ in the final saturated brines (table 5 , analysis 8 ). $1-2 \%$ villiaumite commonly occurs in trona from the upper part of the series, but locally there is as much as $22 \%$ (Baker 1958; Sheppard \& Gude 1969). Fluorite also occurs in Magadi cores and older lake beds where it probably formed by interaction of F-rich brines with gaylussite- and calcite-bearing sediments. Cryolite has not been recorded.

The postulated runoff feeding the Eocene Green River Formation is also not notably rich in $\mathrm{Na}$ and $\mathrm{F}$ (table 5, analysis 7). $\mathrm{F}$ build-up probably followed a pattern similar to that established for Lake Magadi though villiaumite appears not to have formed. Formation of fluorides, including cryolite, occurred after burial presumably by the interaction of F-rich interstitial brines with aluminosilicate sediments (oil shales, dolomitic oil shales). There is probably no need to postulate
F-rich feeder waters (e.g. with a volcanic F component) for the Green River Formation (cf. Gross \& Heinrich 1966, p. 321).

The alkaline Deep Springs Lake, California, also exhibits a significant concentration of $\mathrm{F}$ in the final brines (table 5, analysis 9) (Jones 1965). Carbonates and sulphates, but not fluorides, are recorded so far. At the alkaline Searles Lake evaporite deposit, California, fluorine occurs in the authigenic minerals galeite, schairerite and sulfohalite - mixed salts of $\mathrm{Na}_{2} \mathrm{SO}_{4}, \mathrm{NaF}$ and $\mathrm{NaCl}$ (Smith \& Haines 1964) but the brines at this locality are relatively poor in F (table 5, analysis 10) (Smith 1979).

Other low temperature sediments possess high $\mathrm{Na}$ and $\mathrm{Al}$ contents but low $\mathrm{F}$. Thus the highly alkaline tidal or supratidal flat environment can develop authigenic dawsonite (Goldbery \& Loughnan 1970). Dawsonite is also recorded from saline soils at Olduvai Gorge, Tanzania (Hay 1963).

\section{Agpaitic massifs}

The highest recorded F levels in "natural" water were encountered in deep mines in the alkali-F-rich, agpaitic Lovozero intrusion, U.S.S.R; (table 5, analysis 11). Highly alkaline ( $\mathrm{pH}$ up to 12), waters which had undergone evaporation in the mines contained 1 to $1.5 \% \mathrm{~F}$; they occur in rocks with very high levels of villiaumite (about $3 \%$ ). These waters contain $2.02-2.63 \% \mathrm{Na}$, $0.9-1.3 \% \quad \mathrm{SiO}_{2}$ but relatively low $\mathrm{Al}$ (about $0.1 \%$, single sample), total carbonates $(0.14-0.27 \%)$ and $\mathrm{Cl}(0.006-0.0085 \%)$. This fluosilicate water precipitates stalactites of Na-bearing opal and $\mathrm{Na}$ minerals (trona etc.) (Kraynov et al. 1969). Considerable F occurs in Lovozero natro-opal (0.08-1.27\%) and natron $(6.41 \%)$ (Vlasov et al. 1966).

Cryolite is associated with supergene Lovozero opal (Semenov in Stepanov, 1963), though Dorfman et al. (1967) regard its occurrence as very rare. These authors predicted that cryolite, trona and silica (opal) could develop when nepheline reacts with aqueous solutions rich in $\mathrm{NaF}$ and $\mathrm{CO}_{2}$. Increase in temperature slows down the reaction because of falling concentrations of $\mathrm{CO}_{2}$ and increase in $\mathrm{pH}$ of the solution. Thus the relatively low carbonate contents and high $\mathrm{pH}$ values of the fluosilicate mine waters are not especially favourable for cryolite formation. 
In the agpaitic Ilimaussaq intrusion of South Greenland, powdery trona and thermonatrite have been described from late solution cavities in the mineral ussingite (Sørensen et al. 1970). Semenov (1969, p. 29) noted the presence of white films, probably of secondary aluminofluorides, associated with earthy fluorite in kakortokite pegmatite. Inclusions in quartz from a quartz vein in alkali granite, and in chkalovite from a hydrothermal vein, contain phases with refractive indices close to 1.34 which were tentatively identified as cryolite (Micheelsen 1975).

\section{Alteration of F-rich rocks and minerals}

Various hydrated aluminofluorides are occasionally formed at shallow depths just below or within the oxidation zones of F-rich localities. Examples include mineral deposits with abundant fluorite, sellaite, fluellite or topaz in Kazakhstan, Transbaikal, Tuva, Utah etc. Fault and crush zones combined with suitable hydrography promote the flow of groundwater.

$\mathrm{Na}-$ and $\mathrm{Mg}$-bearing clay gouge from crush zones appears to be a praticularly suitable host material for $\mathrm{Na}-$, $\mathrm{Mg}$-bearing ralstonite (Stepanov \& Moleva 1962). REE-bearing chukhrovite developed in association with supergene REE-rich fluorite and the Sr-bearing tikhonenkovite is found associated with celestine and strontianite. Further discoveries of aluminofluoride species and varieties can be expected from the careful investigation of F-rich mineral deposits.

Weathering crusts containing aluminofluorides have been recorded on skarns in central Kazakhstan, villiaumite at Lovozero, ? fluorite at Ilímaussaq and, in the case of gearksutite, at virtually all occurrences of cryolite.

Precipitation of cryolite and ralstonite Cryolite is more soluble in water than fluorite but less soluble than villiaumite. Cryolite solubility in water increases from $0.30 \mathrm{~g} / \mathrm{l}$ at $0^{\circ} \mathrm{C}$ to $0.75 \mathrm{~g} / \mathrm{l}$ at about $95^{\circ} \mathrm{C}$ (Buchwald 1940) and is probably. even higher in the presence of other solutes as in natural waters.

According to Roberson \& Hem (1968 1973) cryolite and a ralstonite-like material can be readily precipitated from aqueous solutions in the laboratory. At $25^{\circ} \mathrm{C}$ and 1 atmosphere pressure, the activity product for the reaction (in water):

$$
\mathrm{Na}_{3} \mathrm{AlF}_{6} \rightleftharpoons 3 \mathrm{Na}^{+}+\mathrm{Al}^{3+}+6 \mathrm{~F}^{-}
$$

can be taken as $10^{-34.0+0.3}$. Equilibrium was approached from both supersaturation and undersaturation. Cryolite was precipitated in relatively pure form if the $\mathrm{pH}$ was above 8.3. At lower $\mathrm{pH}$ values, the precipitates are mixtures of cryolite and a basic aluminium fluoride with the $\mathrm{X}$-ray pattern of ralstonite.

In terms of ionic species, contents of $\mathrm{AlF}_{6}{ }^{3-}$ are probably negligible in natural waters. In the presence of $\mathrm{Al}^{3+}$ and $\mathrm{Fe}^{3+}$, fluoride ions will preferentially form $\mathrm{AlF}^{2+}, \mathrm{AlF}_{2}^{+}$and $\mathrm{FeF}^{2+}$ while $\mathrm{SiF}_{6}^{2-}$ is a possible species in the $\mathrm{Si}-$, F-rich waters which occasionally occur in volcanic condensates (Roberson \& Barnes 1978).

Hem (1972) thought that cryolite could limit the solubility of aluminium in natural solutions having more fluoride than is normal. At higher sodium concentrations, less fluoride is required. However, in nature the need for unusually high concentrations of $\mathrm{F}, \mathrm{Na}$ and $\mathrm{Al}$ explains the rarity of cryolite. In addition, the presence of solutes other than those occurring in the cryolite structure may inhibit or prevent its formation, though this has not been extensively tested. In the presence of $45-300 \mathrm{mg} / 1 \mathrm{SiO}_{2}$, cryolite is still readily precipitated (Hem et al. 1973). Natural phases competing for the constituent ions of cryolite include gibbsite, fluorite, sellaite $\left(\mathrm{MgF}_{2}\right)$, halite, fluorapatite, trona, dawsonite and villiaumite. The distribution of $F$ in the normally dilute, natural waters is generally controlled by the solubility of fluorite (Ellis \& Mahon 1967) and to a lesser extent by fluorapatite, clays and biota. F-rich natural waters also precipitate fluorite and more rarely villiaumite, sellaite, kogarkoite and F-bearing opal. The low-temperature precipitation of cryolite or ralstonite, as in the experiments of Roberson \& Hem (1968 1973), is only known from late fissures and vughs in aluminofluoride deposits, e.g. Ivigtut. The aluminofluorides of oxidation zones, weathering crusts, alkaline lakes, hot springs and volcanic ash were all formed by the interaction of groundwater (or trapped brines) with rocks and minerals. 


\section{Role of $\mathrm{CO}_{2}$ in aluminofluoride formation}

While there is clear evidence that aluminosilicates may react with $\mathrm{F}^{-}$-bearing solutions to form aluminofluorides, it seems that these reactions can also be promoted by the presence of $\mathrm{CO}_{2}$ or carbonate ions. The possible role of $\mathrm{CO}_{2}$ in the Ivigtut cryolite deposit was considered by Stormer \& Carmichael (1970) using the reaction:

$$
\begin{gathered}
\text { albite }+ \text { acmite }+\mathrm{F}_{2}+\mathrm{CO}_{2} \rightarrow \mathrm{Na}_{3} \mathrm{AlF}_{6}+\text { sid- } \\
\text { erite }+ \text { quartz }+\mathrm{O}_{2}
\end{gathered}
$$

When the activity of the other components is fixed, greater $\mathrm{CO}_{2}$ fugacities will promote cryolite formation. Dorfman et al. (1967) found that solutions of $\mathrm{NaF}$ only decomposed nepheline to give cryolite when $\mathrm{CO}_{2}$ was present. Similarly, beryl only breaks down to aluminofluorides when reaction solutions contain $\mathrm{Al}^{3+}, \mathrm{F}^{-}$and $\mathrm{CO}_{3}{ }^{2-}$. Reaction with aqueous $\mathrm{AlF}_{3}$ solutions yields topaz, quartz and bertrandite (Klyakhin \& Lebedev 1974).

The importance of $\mathrm{CO}_{2}$ in natural aluminofluoride formation is indicated by (i) the occurrence of siderite at cryolite localities $1,4,8$, 9,13 and 17, (ii) carbonatites at localities 12 and 13, (iii) limestone at locality 11 and varied sedimentary carbonates at 14 and several gearksutite localities, (iv) the presence of the fluocarbonate phase bastnäsite at localities 5,9 and 20 and ( $v$ ) the restriction of tikhonenkovite to a siderite deposit. Thus, according to these natural occurrences and the isotopic work on carbon at Volynia, the $\mathrm{CO}_{2}$ may be either magmatic or endogene.

Acknowledgements. The continued interest and stimulation of Professor H. Pauly is gratefully acknowledged. Dr. Emil Makovicky and stud. scient. Kai Willadsen kindly translated several Russian articles. Thanks are due to $O$. Larsen, mag. scient. and ing. Aelita Demina for respectively providing the Danish and Russian abstracts.

\section{Dansk sammendrag}

Oversigten bygger på en gennemgang af 17 sikre forekomster af kryolit og 19 forekomster af andre aluminiumfluorider. Det fremgår, at aluminiumfluorider kan koncentreres i 4 geologiske miljøer: i det granitiske, i det karbonatitiske, i det vulkanske og i det exogene miljø.

Kryolit, delvis replaceret af andre aluminiumfluorider, dannes under det post-magmatiske stadium af graniters udvikling $\mathbf{i}$ pegmatiter tilhørende alkaligraniter, i albitiserede riebeckitgraniter og $i$ hydrotermale malmforekomster. De tilhørende graniter er post- eller non-orogene, sene intrusioner ofte knyttet til regional forkastningstektonik. De er rige på $\mathrm{Na}$ og F, fattige på $\mathrm{Ca}$ og har et lavt indhold af normativ anorthit, akmit og natriumsilikat. Disse graniter karakteriseres også ved høje indhold af $\mathrm{Rb}, \mathrm{Zr}_{\mathbf{r}}$, Nb og de sjaldne jordarter. De afspekler ligevagte ved 1-2 kilobar vanddamptryk i overensstemmelse med deres epizonale placering. Eksperimenter i granit- $\mathrm{H}_{2} \mathrm{O}-\mathrm{HF}$ systemet viser, at aluminiumfluorider dannes $i$ den coexisterende superkritiske dampfase. Afkøling af denne har i Volyn pegmatiterne $i$ Ukraine ført til dannelse af inklusioner med flere faser, blandt andet kryolit og elpasolit. Ved post-magmatisk autometasomatose ekstraheres og derpå genafsattes $\mathrm{F}$, Na og andre grundstoffer via vasker, der indeholder fluoridholdige kompleksioner. Metasomatiske kvarts-feldspat-bjergarter i Østsibirien er dannet $i$ tilknytning til regional metamorfose og deformationer langs dybtgående forkastninger.

Sjældent forekommende karbonatiter og silico-karbonatiter med høje indhold af $\mathrm{Na}$ koncentrerer $\mathrm{F}$ i sene hydrotermale opløsninger, hvilket har ført til kryolitdannelse ved Goldie, Colorado, og Francon Quarry, Montreal.

Ralstonit er udbredt, hvorimod elpasolit og weberit er sjaldne, ved fumaroler og HF-metasomatisk omdannede lavaer tilhørende basiske til intermediære vulkaner. Disse mineraler blev dannet ved temperaturer på $300-100^{\circ} \mathrm{C}$. Varme kilder og afstrømningsvand fra vulkaner har relativt højt F-indhold, og lejlighedsvis dannes gearksutit og creedit ved reaktion med aluminiumsilikater. Kryolit optræder som et sjældent authigent mineral i sedimenter tilhorende Green River formationen i det vestlige USA. F-rige interstitielle saltopløsninger, udviklet som i nutidens Lake Magadi i Kenya, har sandsynligvis været i stand til at reagere med aluminiumsilikater i værtssedimentet. Gearksutit og creedit samt fem andre nyligt opdagede aluminiumfluorider findes tilknyttet nogle F-rige malmforekomster, hvor de optræder $i$ eller lige under oxidationszonen eller $i$ forvitringsskorper. Syntetisk har man udfældet aluminiumfluorider ved lav temperatur, men denne dannelsesmåde kendes ikke i naturen.

Det eneste okonomisk betydningsfulde aluminiumfluorid, kryolit, fandtes i en mængde på flere millioner tons ved Ivigtut $i$ Sydgrønland. Fluor blev koncentreret umiddelbart under et uigennemtrangeligt tag i et smalt, cylindrisk granitlegeme.

\section{References}

Afanas'ev, M. S. 1949: Cryolithionite: In: Minerals of the Ilmen reservation. Akad. Nauk S.S.S.R., Moscow-Leningrad, p. 579 (in Russian).

Allmann, R. \& Koritnig, S. 1972: Fluorine. In: K. H. Wedepohl (Editor), Handbook of Geochemistry, Vol. II/1. Springer, Berlin, Chapter 9.

Arkhangel'skaya, V. V. 1968: Tantal-niobium ores in ancient metasomatic rocks of E. Siberia. Geol. Rudn. Mestorozhd. 10 (5): $29-40$ (in Russian).

Arkhangel'skaya, V. V. 1974: Neighborite from eastern Siberia. Dokl. Acad. Sci, U.S.S.R., Earth Sci. Sect. 210: 131-134.

Arkhipchuk, R. Z. 1971: Gearksutite from the Manzhinsk deposit. L'vov Gos. Univ. Mineral. Sb. 25 (2): 181-184 (in Russian).

Bailey, J: C. 1977: Fluorine in granitic rocks and melts: A review. Chem. Geol. 19: 1-42.

Bailey, J. C. Geology and geochemistry of the Ivigtut granite. (in preparation).

Baker, B. H. 1958: Geology of the Magadi area. Kenya, Geol. Surv. Kenya, Rep. 42: 1-81. 
Baker P. E., Gass, I. G., Harris, P. G. \& Le Maitre, R. W. 1964: The volcanological report of the Royal Society Expedition to Tristan da Cunha. Philos. Trans. R. Soc. London Ser. A 256: 439-575.

Baldauf, R. 1910: Über das Kryolith-Vorkommen in Grönland. Z. Prakt. Geol. 18: 11-12.

Barker, F., Wones, D. R., Sharp, W. N. \& Desborough, G. A. 1975: The Pikes Peak batholith, Colorado Front Range, and a model for the origin of the gabbro-anorthosite-syenite-potassic granite suite. Precambrian Res. 2: 97-160.

Baumann, L. \& Schlegel, G. 1967: Zur Geologie und Mineralisation der Zinnerzlagerstätte Altenberg. Freiberg. Forschungsh. C218: 9-34.

Beer, K. E. 1951: The petrology of some of the riebeckite-granites of Nigeria. Geol. Surv. G. B., Rep. 116.

Beer, K. E. 1952: The petrography of some of the riebeckite-granites of Nigeria. Rep. Geol. Surv. At. Energy Div. 116: 1-38.

Bernauer, F. von 1941: Eine Gearksutit-Lagerstätte auf der Insel Vulcano. Z. Dtsch. Geol. Ges. 93: 65-80.

Berthelsen, A. 1962: On the geology of the country around Ivigtut, SW-Greenland. Geol. Rundsch. 52: 269-280.

Berthelsen, A. \& Henriksen, N. 1975: Geological map of Greenland 1:100,000. Ivigtut 61 V. 1 Syd. The orogenic and cratogenic geology of a Precambrian shield area. Medd. Granl. 186 (1).

Berthelsen, A. \& Noe-Nygaard, A. 1965: The Precambrian of Greenland. In: K. Rankama (Editor), The Precambrian 2. Wiley, New York, pp. 113-262.

Beus, A. A., Severov, E. A., Sitnin, A. A. \& Subbotin, K. D. 1962: Albitized and greisenized granites (apogranites). Nauka, Moscow (in Russian).

Birnie, R. W. \& Hall, J. H. 1974: The geochemistry of El Misti volcano, Peru fumaroles. Bull. Volcanol. 38 (1): 1-15.

Birrell, K. S. 1961: Ion fixation by allophane. N.Z.J. Sci. 4: $393-414$.

Blaxland, A. B. 1976: Rb-Sr isotopic evidence for the age and origin of the Ivigtut granite and associated cryolite body, South Greenland. Econ. Geol. 71: 864-869.

Bond, G. W. 1945: A geochemical survey of the underground water supplies of the Union of South Africa. Geol. Surv. S. Afr. Mem. 41: 1-208.

Borley, G. D., Beckinsale, R. D., Suddaby, P. \& Durham, J. J. 1976: Variations in composition and $\delta^{18} \mathrm{O}$ values within the Kaffo albite-riebeckite granite of Liruei Complex, Younger Granites of Nigeria. Chem. Geol. 18: 297-308.

Bowden, P. 1970: Origin of the Younger Granites of northern Nigeria. Contrib. Mineral. Petrol. 25: 153-162.

Bowden, P. \& van Breemen, O. 1972: Isotopic and chemical studies on Younger Granites from northern Nigeria. In: T. F. J. Dessauvagie \& A. J. Whiteman (Editors), African Geology, Ibadan 1970. Geol. Dept. Univ. Ibadan, Nigeria, pp. 105-120.

Bowden, P. \& Turner, D. C. 1974: Peralkaline and associated ring-complexes in the Nigeria-Niger province, West Africa. In: H. Sørensen (Editor), The Alkaline Rocks. Wiley, London, pp. 330-351.

Bower, C. A. \& Hatcher, J. T. 1967: Adsorption of fluoride by soils and minerals. Soil Sci. 103: 151-154.

Bridge, P. J. 1968: List of cave minerals in the Simpson and Mineral Division collections of Western Australian Government Chemical Laboratories. Western Caver 8: 43-55.

Bridge, P. J. 1973: List of minerals in the Simpson and Mineral Division collections of Western Australian Government Chemical Laboratories. Western Caver 13: 193-197.

Brown, G. C. \& Bowden, P. 1973: Experimental studies concerning the genesis of the Nigerian Younger Granites. Contrib. Mineral. Petrol. 40: 131-139.
Buchanan, M. S., MacLeod, W. N. \& Turner, D. C. 1971: The geology of the Jos Plateau. Vol. 2, Younger Granite Complexes. Geol. Surv. Niger., Bull. 32: 1-169.

Buchwald, H. 1940: Kryolits opløselighed og dissociation in vandige opløsningsmidler. Nordiske Kemikermøde, Forh. 5: 259-260.

Butuzov, B. P., Khetchikov, L. N. \& Shaposhnikov, A. A. 1971: Inclusions in synthetic crystals and their significance in thermobarometry of minerals. In: N. P. Ermakov \& L. N. Khetchikov (Editors), Investigations of mineral-forming solutions and melts in inclusions in minerals. Tr. Vses. Nauchno-Issled. Inst. Sint. Miner. Syrya, 14: 7-14 (in Russian).

Bøggild, O. B. 1953: The mineralogy of Greenland. $\overline{M e} \bar{d} \bar{d}$. Grønl. 149 (3): 1-442.

Campbell, D. F. 1947: Geology of the Colquiri tin mine. Econ. Geol. 42: 1-21.

Carmichael, I. S. E. \& MacKenzie, W. S. 1963: Feldspar-liquid equilibria in pantellerites: An experimental study. $A m$. $J$. Sci. 261: 382-396.

Carobbi, G. 1936: Eluoro di alluminio, magnesio e calcio, bisolfato sodico, merkallite ed hierarite fra i prodotti della attivita fumarollica vesuviana del 1934. Atti Mem. Accad. Naz. Sci. Lett. Arti, Modena ser. 5, 1: 33-42.

Carobbi, G. \& Cipriani, C. 1951: Richerche su alcuni prodotti delle fumarole vesuviane. Rend. Soc. Ital. Mineral. Petrol. 7: 43-44.

Chao, E. C. T., Evans, H. T., Jr., Skinner, B. J. \& Milton, C. 1961: Neighborite, $\mathrm{NaMgF}_{3}$, a new mineral from the Green River Formation, South Ouray, Utah. Am. Mineral.' 46: 379-393.

Chukhrov, F. V. 1960: Mineralogy and zoning in the Eastern Kounrad. Tr. Inst. Geol. Rudn. Mestorozhd., Petrogr., Mineral. i Geokhim. 50: 5-237 (in Russian).

Clark, T. H. 1972: Montreal area. Que. Dep. Nat. Res., Geol. Rep. 152.

Cook, R. B., Jr. 1975: The occurrence of creedite at Colquiri, Inquisivi Province, Department of La Paz, Bolivia. Mineral. Rec. 6: 278-281.

Cooper, A. F., Gittins, J. \& Tuttle, O. F. 1975: The system $\mathrm{Na}_{2} \mathrm{CO}_{3}-\mathrm{K}_{2} \mathrm{CO}_{3}-\mathrm{CaCO}_{3}$ at 1 kilobar and its significance in carbonatite petrogenesis. Am. J. Sci. 275: 534-560.

Craig, D. F., Cassidy, R. T. \& Brown, J. J., Jr. 1978: A review of phase equilibriums in the cryolite $\left(\mathrm{Na}_{3} \mathrm{AlF}_{6}\right)$ - lithium fluoride - calcium fluoride - aluminium fluoride - alumina system. Natl. Bur. Stand. (U.S.), Spec. Publ. 496 (Vol. 1): 272-345.

Cross, W. \& Hillebrand, W. F. 1883: On minerals of the cryolite group recently found in Colorado. Am. J. Sci. 26: 271-294.

Cross, W. \& Hillebrand, W. F. 1885: Contributions to the mineralogy of the Rocky Mountains. U.S. Geol. Surv., Bull. 20: 40-74.

Davies, W. E. 1958: Caverns of West Virginia. W. Va., Geol. Econ. Surv., Bull. 19A.

Davis, S. N. \& DeWiest, R. J. M. 1966: Hydrogeology. Wiley, New York.

Dawson, J. B. 1966: Oldoinyo Lengai - an active volcano with sodium carbonatite lava flows. In: O. F. Tuttle \& J. Gittins (Editors), Carbonatites. Interscience, New York, pp. 155-168.

Day, D. T. 1887: Mineral resources of the United States. Calendar Year 1886. Government Printing Office, Washington, D. C.

Deans, T. 1966: Economic mineralogy of African carbonatites. In: O. F. Tuttle \& J. Gittins (Editors), Carbonatites. Interscience, New York, pp. 385-413.

Deans, T., Sukheswala, R. N., Sethna, S. F. \& Viladkar, S. G. 1972: Metasomatic feldspar rocks (potash fenites) as- 
sociated with the fluorite deposits and carbonatites of Amba Dongar, Gujarat, India. Trans. Inst. Min. Metall. Sec. B, v. 81, Bull. 783: B1-B9.

Desborough, G. A., Pitman, J. K. \& Huffman, C., Jr. 1976: Concentration and mineralogical residence of elements in rich oil shales of the Green River Formation, Piceance Creek basin, Colorado, and the Uinta Basin, Utah. Chem. Geol. 17: 13-26.

Dietrich, R. V., Heier, K. S. \& Taylor, S. R. 1965: Studies on the igneous rock complex of the Oslo Region. XX Petrology and geochemistry of ekerite. Skr. Nor. Vidensk.Akad. Oslo, I, Mat.-Naturvidensk., Kl., Ny Ser., 19: 31 pp.

Di Girolamo, P. \& Franco, E. 1968: Ralstonit nelle fratture fumarolizzate del tufo campano di S. Prisco (Caserta). Atti Accad. Sci. Fis. Mat. Napoli 7, ser. 3, 1: 1-18.

Dontsova, E. I., Milovskiy, A. V. \& Mel'nikov, F. P. 1972: Fractionation of oxygen isotopes during formation of pegmatites. Geochem. Int. 9: 351-355.

Dorfman, M. D., Goroshchenko, Ya.G., Sikorskaya, E. K. \& Dorfman, A. M. 1967: Reaction between nepheline and aqueous solutions of sodium fluoride and carbon dioxide. Geochem. Int. 4: 669 (abstract) and Geokhimiya: 786-795 (in Russian).

Dunn, P. J. \& Fryer, C. W. 1976: Prosopite, an effective turquoise substitute. J. Gemmol. 15: 165-171.

Dunn, P. J., Peacor, D. R. \& Sturman, B. D. 1979: Carlhintzeite, a new calcium aluminium fluoride hydrate from the Hagendorf pegmatites, Bavaria, Germany. Can. Mineral. 17: 103-105.

Eadington, P. J. \& Nashar, B. 1978: Evidence for the magmatic origin of quartz-topaz rocks from the New England batholith, Australia. Contrib. Mineral. Petrol. 67: 433-438.

Eborall, M. I. \& Wright, J. B. 1974: Comments on "Experimental studies concerning the genesis of the Nigerian Younger Granites" by G. C. Brown \& P. Bowden (Contr. Mineral. and Petrol. 40, 131-139, 1973). Contrib. Mineral. Petrol. 43: 159-161.

Efimov, A. F. \& Ganzeev, A. A. 1972: Microclinized granite-aplites of the Burpala massif (mineralogy and problems of genesis). In: Deposits of rare metals, genesis and methods of investigation. Moscow, pp. 179-189 (in Russian).

Ellis, A. J. \& Mahon, W. A. J. 1967: Natural hydrothermal systems and experimental hot water/rock interaction (Part II). Geochim. Cosmochim. Acta 31: 519-538.

Emel'yanova, E. N. \& Zigareva, T. A. 1960: Production of tourmaline under hydrothermal conditions. Kristallografiya 5: 955-957 (in Russian).

Emmons, W. H. \& Larsen, E. S. 1913: The hot springs and the mineral deposits of Wagon Wheel Gap, Colorado. Econ. Geol. 8: 235-246.

Ermilova, L. P. 1963a: Gearksutite. In: F. V. Chukhrov \& E. M. Bonshtedt-Kupletskaya (Editors), Minerals. Vol. IL, Part 1. Halogenides. Akad. Nauk S.S.S.R., Moscow, pp. 103-107 (in Russian).

Ermilova, L. P. 1963b: Creedite. In: F. V. Chukhrov \& E. M. Bonshtedt-Kupletskaya (Editors), Minerals. Vol. II, Part 1. Halogenides. Akad. Nauk S.S.S.R., Moscow, pp. 98-102 (in Russian).

Ermilova, L. P. 1964: Minerals of the molybdenum-wolfram deposit of Karaoba in central Kazakhstan. Akad. Nauk S.S.S.R., Inst. Geol. Rudn. Mestorozhd., Petrogr., Mineral. $i$ Geokhim. Nauka, Moscow, 175 pp. (in Russian)

Ermilova, L. P. \& Moleva, V. A. 1953: On creedite from Kazakhstan. Dokl. Akad. Nauk, S.S.S.R. 88 (5): 905-908 (in Russian).
Ermilova, L. P., Moleva, V. A. \& Klevtsova, R. F. 1960: Chukhrovite - a new mineral from Central Kazakhstan. Zap. Vses. Mineral. Ova. 89 (1): 15-25 (in Russian).

Eugster, H. P. 1970: Chemistry and origin of the brines of Lake Magadi, Kenya. Mineral. Soc. Am., Spec. Pap. 3: 213-235.

Evtyukhina, I. A., Kogarko, L. N., Kunin, L. L., Malkin, V. I. \& Rudchenko, L. N. 1967: The acid-base properties of some aluminosilicate melts. Simplified rock analog. Dokl. Akad. Nauk, S.S.S.R. 175: 1369-1371 (in Russian).

Fersman, A. E. 1940: Pegmatites. Vol. I. Granite pegmatites. Akad. Nauk S.S.S.R., Moscow (in Russian).

Fijal, J. \& Tokarz, M. 1975: Studies on the fluoderivatives of silicate minerals with layered structure. I Some aspects of the reaction of kaolinite with fluoride solutions. Miner. Polonica 6: 59-69.

Foshag, W. F. 1921: The crystallography and chemical composition of creedite. Proc. Natl. Mus. 59: 419-424.

Foshag, W. F. 1932: Creedite from Nevada. Am. Mineral. 17: $75-77$.

Freeth, S. J. 1972: The petrogenesis of the Younger Granites of northern Nigeria and southern Niger. In: T. F. J. Dessauvagie \& A. J. Whiteman (Editors), African Geology, Ibadan 1970. Geol. Dept. Univ. Ibadan, Nigeria, pp. 121-126.

Frenzel, G. 1953: Über Creedit von Colquiri, Bolivien. Neues Jahr. Mineral. Monatsh. 241-246.

Frondel, C. 1948: New data on elpasolite and hagemannite. Am. Mineral. 33: 84-87.

Galetskii, L. S. \& Zinchenko, O. V. 1972: Fluorine in rocks of the northwestern part of the Ukrainian Shield. Sb. Nauchn. Rab., Nauchno-lssled. Sekt., Kiev. Gos. Univ. 8: 97-102 (in Russian).

Ganzeev, A. A. \& Sotskov, Yu. P. 1976: Rare earth elements in fluorite of different genesis. Geokhimiya (3): 390-395 (in Russian).

Ganzeev, A. A., Yefimov, A. F. \& Lyubomilova, G. B. 1969: Plumbobetafite - a new mineral variety from the pyrochlore group. Tr. Mineral. Muz., Akad. Nauk S.S.S.R. 19: 135-137 (in Russian).

Gavrusevich, B. A. 1932: Contributions a l'étude de la minéralogie des pegmatites de topaze en Ukraïne. Dokl. Akad. Nauk, S.S.S.R. 173-181.

Gemitz, F. E. 1876: Nakrit nach Prosopit und ? Topas. Neues Jahr. Mineral. Geol. Palaeontol. 492-494.

Ginzburg, A. I. \& Fel'dman, L. G. 1977: Deposits of tantalum and niobium. In: V. I. Smirnov (Editor), Ore Deposits of the USSR, Vol. III. Pitman, London, pp. 372-424.

Ginzburg, A. I., Kudrin, V. S. \& Atkhangel'skaya, V. V. 1970: Metasomatic rocks of alkali granite composition $=\mathbf{a}$ new possible source for cryolite. Razved. Okhr. Nedr. 5: 5-8 (in Russian).

Glyuk, D. S. \& Anfilogov, V. N. 1973: Phase equilibria in the system granite- $\mathrm{H}_{2} \mathrm{O}-\mathrm{HF}$ at a pressure of $1000 \mathrm{~kg} / \mathrm{cm}^{2}$. Geochem. Int. 10: 321-325.

Goldbery, R. \& Loughnan, F. C. 1970: Dawsonite and nordstrandite in the Permian Berry Formation of the Sydney Basin, New South Wales. Am. Mineral. 55: 477-491.

Gorokhov, I. M. 1964: Whole-rock Rb-Sr ages of the Korosten' granites, Dnieper migmatites and metamorphosed mafic rocks of the Ukraine. Geochem. Int. 738-746.

Govorov, I. N. 1958: Features of the mineralogy and genesis of the tin-beryllium-fluorite deposits of the Far East. Akad. Nauk S.S.S.R., Ser. Geol. 47-55.

Grigoriev, I. F. \& Dolomanova, E. I. 1959: On gearksite. Tr. Mineral. Muz., Akad. Nauk S.S.S.R. 10: 185-186 (in Russian). 
Gross, E. B. \& Heinrich, E. W. 1965: Petrology and mineralogy of the Mount Rosa area, El Paso and Teller counties, Colorado. I The granites. Am. Mineral. 50: 1273-1295.

Gross, E. B. \& Heinrich, E. W. 1966: Petrology and mineralogy of the Mount Rosa area, El Paso and Teller counties, Colorado. II Pegmatites. Am. Mineral. 51: 299-323.

Gruner, J. W., Fetzer, W. G. \& Rapaport, I. 1951: The uranium deposits near Marysvale, Piute county, Utah. Econ. Geol. 46: 243-251.

Gurov, Ye. P. \& Gurova, Ye. P. 1970: Prosopite and its alteration products from metasomatic rocks in the northwestern part of the Ukrainian shield. Dokl. Acad. Sci., U.S.S.R., Earth Sci. Sect. 194: 125-127.

Gurov, Ye. P. \& Gurova, Ye. P. 1973: Pachnolite and thomsenolite from crystalline rocks of the Ukraine. Dokl. Acad. Sci., U.S.S.R., Earth Sci. Sect. 202: 143-145.

Gurov, Ye. P. \& Gurova, Ye. P. 1974: Fluocerite from metasomatic rocks of the Ukrainian Shield. L'vov Gos. Univ. Mineral. $S b .28$ (4): 41-43 (in Russian).

Gurov, Ye. P. \& Marchenko, Ye. Ya. 1970: Relation of genthelvite and phenakite in beryllium-bearing metasomatites. Geol. Rudn. Mestorozhd. 12: 107-110.

Gurov, Ye. P., Gurova, Ye. P. \& Marchenko, Ye. Ya. 1969: Gearksutite from metasomatic rocks in the northwest Ukrainian crystalline shield. Dopov. Akad. Nauk Ukr. R.S.R. Ser. B, 2: 109-112 (in Ukrainian).

Gurov, Ye. P., Gurova, Ye. P. \& Marchenko, Ye. Ya. 1970: Weberite from metasomatic rocks of the Ukrainian shield. Dokl. Acad. Sci., U.S.S.R., Earth Sci. Sect. 191: 103-105.

Gurov, Ye. P., Gurova, Ye. P. \& Marchenko, Ye. Ya. 1971: First occurrence of cerian fluorite in the Ukraine. Dopov. Akad. Nauk Ukr. R.S.R. Ser. B, 4: 297-299 (in Ukrainian).

Gurov, Ye. P., Marchenko, Ye. Ya. \& Ponomar'ova, R. G. 1972: New data on the mineralogy of aluminium fluorides in metasomatic rocks of the Ukraine. Dopov. Akad. Nauk $U k r$. R.S.R. Ser. B, 7: 582-585 (in Ukrainian).

Gurov, Ye. P., Gurova, Ye. P., Ponomareva, R. G. \& Slysh, R. A. 1975a: On the form of alumofluorides development in the rare-metal metasomatites of the Ukraine. Geol. Zh. 35 (4): 35-41 (in Russian).

Gurov, Ye. P., Gurova, Ye. P., Loginova, L. G. \& Lavitskaya, Yu. A. 1975b: Fluocerite from pegmatites and metasomatites of the northwestern part of the Ukrainian Shield. Zap. Vses. Mineral. Ova. 104: 455-458 (in Russian).

Guy, B. B. \& Jeffrey, G. A. 1966: The crystal structure of fluellite, $\mathrm{Al}_{2} \mathrm{PO}_{4} \mathrm{~F}_{2}(\mathrm{OH}) .7 \mathrm{H}_{2} \mathrm{O}$. 'Am. Mineral. 51: 1579-1592.

Hards, N. 1976: Distribution of elements between the fluid phase and silicate melt phase of granites and nepheline syenites. In: G. M. Biggar (Editor), Progress in Experimental Petrology. Third Progress Report of Research Supported by N.E.R.C. at Edinburgh and Manchester Universities, 1972-1975. The Natural Environment Research Council Publication Series D, No. 6: 88-90.

Hay, R. L. 1963: Zeolitic weathering in Olduvai Gorge, Tanzania. Bull. Geol. Soc. Am. 74: 1281-1286.

Heinrich, E. W. 1977: Aluminofluoride minerals of the Goldie carbonatite, Fremont County, Colorado. Mt. Geol. 14(2): 33-46.

Heinrich, E. W. \& Anderson, R. J. 1965: Carbonatites and alkalic rocks of the Arkansas River area, Fremont County, Colorado. 2. Fetid gas from carbonatite and related rocks. Am. Mineral. 50: 1914-1920.

Heinrich, E. W. \& Dahlem, D. H. 1970: Dikes of the McClure Mountain-Iron Mountain alkalic complex, Fremont County, Colorado, U.S.A. Bull. Volcanol. 33: 960-976.

Heinrich, E. W. \& Quon, S. H. 1963: New type of deposit of aluminofluoride minerals from Fremont County, Colorado. (abstract). Geol. Soc. Am., Spec. Pap. 73: 169.
Heinrich, E. W. \& Shappirio, J. R. 1966: Alkalic rocks and carbonatites of the Arkansas River Canyon, Fremont County, Colorado. 3. The amethyst carbonatites. Am. Mineral. 51: 1088-1106.

Hem, J. D. 1972: Aluminium, G-L. In: K. H. Wedepohl (Editor), Handbook of Geochemistry, Vol. II/1. Springer, Berlin, Chapter 13.

Hem, J. D., Roberson, C. E., Lind, C. J. \& Polzer, W. L. 1973: Chemical interactions of aluminium with aqueous silica at $25^{\circ}$ C. U.S. Geol. Surv., Water-Supply Pap. 1827-E: 57 pp.

Henderson, E. P. 1929: Gearksutite from Virginia. Am. Mineral. 14: 281-285.

Herman, P., Vanderstappen, R. \& Hubaux, A. 1960: Sublimates of Nyiragongo (Kivu). Bull. Acad. Roy. Sci. d'Outre-Mer, Brussels 6: 961-971.

Herzenberg, R. 1949: Novedades de la mineralogía Boliviana. Publ. Tecn. Inst. Boliviano Ingen. Minas y. Geol. 4 pp.

Hillebrand, W. F. 1899: Mineralogical notes: Analyses of tysonite, bastnäsite, prosopite, jeffersonite, covellite, etc. $A m$. J. Sci. 7: 51-57.

Hitchon, B., Holloway, L. R. \& Bayliss, P. 1976: Formation of ralstonite during low-temperature acid digestion of shales. Can. Mineral. 14: 391-392.

Holm, J. L. 1963: Undersøkelser av struktur og faseforhold for a en del systemer med tilknyting til aluminiumelektrolysen. Lic. thesis, Institute of Inorganic Chemistry, The Technical University of Norway, Trondheim. $105 \mathrm{pp}$.

Huang, P. M. \& Jackson, M. L. 1965: Mechanism of reaction of neutral fluoride solution with layer silicates and oxides of soils. Soil Sci. Soc. Am., Proc. 29: 661-665.

Ivantishin, M. I., Koulskaya, O. A., Gornyi, G. Y. \& Eliseeva, G. D. 1964: Granitoids of Ukrainian crystalline shield, their geologic and geochemical peculiarities and their rare-earth mineralization. Geochem. Int. 1: 372-387.

Jacobson, R. R. E., McLeod, W. N. \& Black, R. 1958: Ring-complexes in the Younger Granite province of Northern Nigeria. Mem. Geol. Soc. London 1: 1-72.

Jambor, J. L., Fong, D. G. \& Sabina, Ann P. 1969: Dresserite, the new barium analogue of dundasite. Can. Mineral. 10: 84-89.

Jambor, J. L., Plant, A. G. \& Steacy, H. R. 1976: A dawsonite-bearing silicocarbonatite sill from Montreal Island, Quebec. Geol. Surv. Can., Pap. 76-1B: 357-362.

James, R. S. \& Hamilton, D. L. 1969: Phase relations in the system $\mathrm{NaAlSi}_{3} \mathrm{O}_{8}-\mathrm{KAISi}_{3} \mathrm{O}_{8}-\mathrm{CaAl}_{2} \mathrm{Si}_{2} \mathrm{O}_{8}-\mathrm{SiO}_{2}$ at 1 kilobar water vapour pressure. Contrib. Mineral. Petrol. 21: 111-141.

Jones, B. F. 1965: The hydrology and mineralogy of Deep Springs Lake, Inyo County, California. U.S. Geol. Surv., Prof. Pap. 502-A: 56 pp.

Jones, B. F., Eugster, H. P. \& Rettig, S. L. 1977: Hydrochemistry of the Lake Magadi basin, Kenya. Geochim. Cosmochim. Acta 41: 53-72.

Kalyuzhny, V. A. 1956: Phase transformations in liquid inclusions. Mineral. Sb. L'vov Geol. Ova. pri Univ. 10: 77-80 (in Russian).

Kalyuzhny, V. A. 1962: The study of the composition of captive minerals in polyphase inclusions: L'vov. Int. Geol. Rev. 4: 127-138.

Kalyuzhny, V. A. \& Gigashvili, G. M. 1972: Physical-chemical properties of the formation of cavity pegmatites of the Ukraine. L'vov Gos. Univ. Mineral. Sb. 26 (3): 247-256 (in Russian).

Kalyuzhnaya, K. M., Muzhanovskiy, F. V. \& Solovieva, T. V. 1973: On the metasomatic changes of the pegmatites of Volhyn. Vop. Litol. Petrogr. 2: 143-152 (in Russian).

Karup-Meller, S. 1973: A gustavite-cosalite-galena bearing mineral suite from the cryolite deposit at Ivigtut, south Greenland. Medd. Grønl. 195 (5): 40 pp. 
Karup-Møller, S. \& Pauly, H. Galena and associated ore minerals from the cryolite deposit at Ivigtut, South Greenland. Greenland Geo-Science Ser. 2: 1-25 (in press).

Khamatova, N. A., Mogarovskiy, V. V. \& Talaluyeva, N. I. 1970: Creedite from the oxidation zone of the Dzhaamba fluorite deposits, eastern Pamir. Dokl. Akad. Nauk Tadzh. S.S.R. 13 (10): $42-45$ (in Russian).

Khomyakov, A. P., Stepanov, V. I., Moleva, V. A. \& Pudovkina, Z. V. 1964: The new mineral tikhonenkovite, $\mathrm{SrAlF}_{4}(\mathrm{OH}) \cdot \mathrm{H}_{2} \mathrm{O}$. Dokl. Akad. Nauk S.S.S.R. 156: 345-347 (in Russian).

Klominsky, J. \& Groves, D. I. 1970: The contrast in granitic rock types associated with tin and gold mineralization in Tasmania. Proc. Aust. Inst. Min. Metall. 234: 71-77.

Klyakhin, V. A. \& Lebedev, A. S. 1974: Effect of potassium, lithium, ammonium, calcium, and magnesium on the behaviour of beryl in carbonate and fluoride-carbonate solutions. Eksp. Issled. Mineral. 1972-1973: 136-141 (in Russian).

Kogarko, L. N. 1966: Physico-chemical analysis of cryolite paragenesis. Geokhimiya 1966 (11): 1300-1310 (in Russian).

Kogarko, L. N. 1968 (Publ. 1971): Stability of cryolite under hydrothermal conditions. Tr. Soveshch. Eksp. Tekh. Mineral. Petrogr. 8: 116-120 (in Russian).

Kokscharov, N. von 1862: Materialen zur Mineralogie Russlands. Band IV. Alexander Jacobson, St. Petersburg.

Korzhinskiy, A. F., Vasil'ev, E. K. \& Lebedeva, V. S. 1960 : Phase composition of annealed gearksutite from the Dzhida deposit. Zap. Vses. Mineral. Ova. 89: 669-681.

Kovalenko, N. I. 1977: The reactions between granite and aqueous hydrofluoric acid in relation to the origin of fluorine-bearing granites. Geochem. Int. 14: 108-118.

Kovalenko, V. I. 1973: Distribution of fluorine in a topaz-bearing quartz keratophyre (ongonite) and solubility of fluorine in granitic melts. Geochem. Int. 10: 41-49.

Kozyreva, L. V., Zorina, M. L. \& Romanova, T. S. 1976: Finding of cryolite and dawsonite in the Khibiny Massif. Miner. Paragenezisy Miner. Gorn. Porod. 67-70 (in Russian).

Kraynov, S. R., Mer'kov, A. N., Petrova, N. G., Baturinskaya, I. V. \& Zharikova, V. M. 1969: Highly alkaline (pH 12) fluosilicate waters in the deeper zones of the Lovozero massif. Geochemistry 1969 (6): 635-640.

Kudrin, V. S. 1972: On formation of rare-metallic alkali quartz-feldspar metasomatites in zones of regional metamorphism. Geol. Rudn. Mestorozhd. 14 (5): 41-55 (in Russian).

Kudrin, V. S. \& Kudrina, M. A. 1968: Cryolite and other complex fluorides from metasomatic rocks of East Tuva. $T r$. Mineral. Muz., Akad. Nauk S.S.S.R. 18: 80-91 (in Russian).

Kudrin, V. S., Kudrina, M. A. \& Shuriga, T. N. 1965: Rare-metal metasomatic formations associated with subalkaline granitoids. Geol. Mestorozhd. Redk. Elem. 25. Nedra, Moscow (in Russian).

Kukovskii, E. G. 1962: Effect of certain acids on the structure of palygorskite. Dopov. Nauk Ukr. R.S.R. 8: 1076-1079 (in Ukrainian).

Landes, K. K. 1935: Colorado pegmatites. Am. Mineral. 20: 322-326.

Larsen, E. S. \& Wells, R. C. 1916: Some minerals from the fluorite-barite veins near Wagon Wheel Gap, Colorado. Proc. Natl. Acad. Sci. U.S.A. 2: 360-365.

Lazarenko, N. Ye. 1974: Cryolite - prisoner of Volhynian topaz. L'vov Gos. Univ. Mineral. Sb. 24 (4): 43-45 (in Russian).
Lemmlein, G. G., Kliya, M. O. \& Ostrovskii, I. A. 1962: The conditions for the formation of minerals in pegmatites according to the data on primary inclusions in topaz. Dokl. Akad. Nauk S.S.S.R. 7(1): 4-6 (in Russian).

Leonard, R. J. 1927: The hydrothermal alteration of certain silicate minerals. Econ. Geol. 22: 18-43.

Lewis, J. V. \& Hawkins, A. C. 1931: A Manual of Determinative Mineralogy with Tables. Wiley, New York.

Livingstone, D. A. 1963: Chemical composition of rivers and lakes. In: Data of Geochemistry, 6th Edition. U.S. Geol. Surv., Prof. Pap. 440-G, Ch. G, 64 pp.

Luth, W. C. 1969: The systems $\mathrm{NaAlSi}_{3} \mathrm{O}_{8}-\mathrm{SiO}_{2}$ and $\mathrm{KAl}$ $\mathrm{Si}_{3} \mathrm{O}_{8}-\mathrm{SiO}_{2}$ to $20 \mathrm{~kb}$ and the relationship between $\mathrm{H}_{2} \mathrm{O}$ content, $\mathrm{P}_{\mathrm{H} 2 \mathrm{O}}$ and $\mathrm{P}_{\text {total }}$ in granitic magmas. Am. J. Sci. 267-A: 325-341.

Luth, W. C., Jahns, R. H. \& Tuttle, O. F. 1964: The granite system at pressures of 4 to 10 kilobars. J. Geophys. Res. 69: 759-773.

Lyakhov, Yu. V. 1967: Mineral composition of multiphase inclusions in morions from Volynian pegmatites. Geochem. Int. 4: 618-625.

McIntyre, W. H. 1945: Fluorine content of soil and its determination. Soil Sci. 59: 105-109.

Mackay, R. A. \& Beer, K. E. 1952: The albite-riebeckite granites of Nigeria. Rep. Geol. Surv. At. Energy Div. 95.

Mackay, R. A., Greenwood, R. \& Rockingham, J. E. 1949: The geology of the Plateau tinfields - Re-survey, 1945-48. Geol. Surv. Nigeria, Bull. 19.

Mackay, R. A., Rockingham, J. E. \& Beer, K. E. 1952: The albite-riebeckite granites of Nigeria. H. M. Stat. Off., London.

Mahon, W. A. J. 1964: Fluorine in the natural thermal waters of New Zealand. N. Z. J. Sci. 7: 3-28.

Mamchur, G. P., Matviyenko, A. D. \& Yarynych, O. A. 1975: The genesis of chamber pegmatites in Volhyn based on $\mathrm{C}^{13}$ data. Geol. $2 h .35$ (3): 91-98 (in Russian).

Melcher, G. C. 1966: The carbonatites of Jacupiranga, Sao Paulo, Brazil. In: O. F. Tuttle \& J. Gittins (Editors), Carbonatites. Interscience, New York, pp. 169-181.

Mel'nik, Yu. M. \& Rasumeeva, N. N. 1969: Gearksutite from the Perzhansky granite of Volhyn. L'vov Gos. Univ. Mineral. $S b .23$ (1): 77-81 (in Russian).

Micheelsen, H. 1975: In situ measurements of the refractive indices of liquid and gaseous inclusions in minerals. Fortschr. Mineral. 52: 465-473.

Michel-Lévy, A. \& Wyart, J. 1948: Reproduction synthétique de la chiolite. Bull. Soc. Franc. Mineral. 70: 168-171.

Milton, C. 1971: Authigenic minerals in the Green River Formation. Contrib. Geol., Univ. Wyo. 10 (1): 57-64.

Milton, C. 1977: Mineralogy of the Green River Formation. Mineral. Rec. 8 (5): 368-379.

Mineev, D. A. 1963: Geochemical differentiation of the rare earths. Geochemistry 1129-1149.

Mineev, D. A. 1968: Geochemistry of apogranites and rare-metal metasomatites of northwest Tarbagatay. Nauka, Moscow, 183 pp.

Miroshnichenko, L. A. 1955: On creedite from a skarn deposit in Central Kazakhstan. Akad. Nauk Kaz. S.S.R., Ser. Geol. 19: 135-140 (in Russian).

Mücke, A. 1977: Mineralien aus dem Pegmatite von Hagendorf. Aufschluss 28: 353-358.

Muzhanovsky, F. V., Sorokin, U. G., Panchenko, V. I., Lavrenchuk, M. A. \& Sheigas, N. P. 1970: Distribution peculiarities of some accessory minerals in Ukraine granites lying close to pegmatites. L'vov Gos. Univ. Mineral. Sb. 24 (3): 348-355 (in Russian).

Naboko, S. I. 1941: On a new fluoric mineral occurring in the sublimates of the volcano Klyuchevsky. Dokl. Akad. Nauk S.S.S.R. 33: 140-143 (in Russian). 
Naboko, S. I. 1957: A case of gaseous fluorine metasomatism at an active volcano. Geochemistry $452-455$.

Naboko, S. I. 1959a: Volcanic exhalations and the products of their reactions. Tr. Lab. Vulk. Akad. Nauk S.S.S.R. 16: 303 pp (in Russian).

Naboko, S. I. 1959b: Volcanic exhalations and products of their reactions as exemplified by Kamchatka-Kuriles volcanoes. Bull. Volcanol. 20: 121-136.

Naughton, J. J., Greenberg, V. A. \& Goguel, R. 1976: Incrustations and fumarolic condensates at Kilauea volcano, Hawaii: field, drill-hole and laboratory observations. $J$. Volcanol. Geotherm. Res. 1 (2): 149-165.

Naydenov, B. M., Bogolepov, V. G., Polyvyannyy, E. Ya. \& Zakharchenko, A. I. 1972: Behaviour of argon isotopes in pegmatite mineralizing solutions. Geochem. Int. 9: $471-473$.

Nockolds; S. R. 1954: Average chemical compositions of some igneous rocks. Bull. Geol. Soc. Am. 65: 1007-1032.

Novikova, M. I. 1973: The finding of chukhrovite in Siberia. Zap. Vses. Mineral. Ova. 102 (2): 200-202 (in Russian).

Novikova, M. I., Sidorenko, G. A. \& Kuznetsova, N. N. 1966: Yaroslavite, a new calcium aluminium fluoride. Zap. Vses. Mineral. Ova. 95 (1): $39-44$ (in Russian).

Nozhkin, A. D., Gavrilenko, V. A. \& Moleva, V. A. 1967: Usovite, a new barium fluoaluminate. Zap. Vses. Mineral. Ova. 96: 63-66 (in Russian).

Nozhkin, A. D., Moleva, V. A. \& Chubkova, T. P. 1970: First find of jarlite in the USSR. Zap. Vses. Mineral. Ova. 99: 458-462 (in Russian).

Pabst, A. 1952: A new locality for creedite (Calif.). Rocks Miner. 27: 19.

Pabst, A. \& Sharp, W. N. 1973: Kogarkoite, a new natural phase in the system $\mathrm{Na}_{2} \mathrm{SO}_{4}-\mathrm{NaF}-\mathrm{NaCl}$. Am. Mineral. 58: 116-127.

Parker, R. L. \& Sharp, W. N. 1970: Mafic-ultramafic igneous rocks and associated carbonatites of the Gem Park Complex, Custer and Fremont Counties, Colorado. U.S. Geol. Surv. Prof. Pap. 649: 24 pp.

Pauly, H. 1954: Weberite from Pikes Peak, Colorado. Am. Mineral. 39: 669-674.

Pauly, H. 1956: Bøggildite, a new phosphate-fluoride from Ivigtut, South Greenland. Medd. Grønl. 137 (6): 1-16.

Pauly, H. 1960: Paragenetic relations in the main cryolite ore of Ivigtut, South Greenland. Neues Jahr. Mineral. Abh. 94: 121-139.

Pauly, H. 1962: Stenonite, a new carbonate-fluoride from Ivigtut, South Greenland. Medd. Gronl. 169 (9): 24 pp.

Pauly, H. 1965: Ralstonite from Ivigtut, South Greenland. Am. Mineral. 50: 1851-1864.

Pauly, H. 1974: Ivigtut cryolite deposit, SW-Greenland. In: M. Stemprok (Editor), Metallization Associated with Acid Magmatism, Vol. 1. Geological Survey, Prague, pp. 393-399.

Pauly, H. \& Aho, L. 1959: Petrographic and mineralogical examination of Nigeria granite containing cryolite. Internal Report, Cryolite Company, Copenhagen. 4 pp.

Pavlenko, A. S. 1974: The Mongol-Tuva province of alkaline rocks. In: H. Sørensen (Editor), The Alkaline Rocks. Wiley, London, pp. 271-293.

Pavlenko, A. S., Vainshtein, E. E. \& Shevaleevskii, I. D. 1957: On the hafnium-zirconium ratio in zircons of igneous and metasomatic rocks. Geochemistry 411-430.

Pavlenko, A. S., Chung-Yang, H. \& Morozov, L. N. 1960: Geochemical description of granitoids with accessory tantalo-niobates. Geochemistry 125-143.

Philpotts, A. R. 1974: The Monteregian province. In: H. Sørensen (Editor), The Alkaline Rocks. Wiley, London, pp. 293-310.
Pouclet, A. 1973: Contribution a la connaissance du Volcan Nyiragongo (Rift ouest-africain). Les éruptions intra-craterales de juillet 1971 a avril 1972. Bull. Volcanol. 37: $37-72$.

Povarennykh, A. S. 1973: The new mineral species calcjarlite. Konst. Svoistva Miner. 7: 131-135 (in Russian).

Povarennykh, A. S., Egorova, L. N., Litvin, A. L. \& Nozhkin, A. D. 1974: Chemical composition and unit cell of usovite. Dopov. Akad. Nauk Ukr. R.S.R. 36B (10): 891-893 (in Ukrainian).

Povilyatis, M. M. 1960: Main features of the mineralogy of Dzhida molybdenum-tungsten deposit. Tr. Inst. Geol. Rudn. Mestorozhd., Petrogr. Mineral. i Geokhim. 24: 3-167.

Pudovkina, Z. V. \& Pyatenko, Yu. A. 1970: Structure of prosopite, $\mathrm{Ca}\left(\mathrm{Al}_{2} \mathrm{~F}_{4}(\mathrm{OH})_{4}\right)$, and some crystallochemical features of fluoraluminates. Dokl. Acad. Sci. U.S.S.R., Earth Sci. Sect. 190: 131-133.

Raade, G. 1927: Mineralogy of the miarolitic cavities in the plutonic rocks of the Oslo Region, Norway. Mineral. Rec. 3: 7-11.

Ridge, J. D. 1972: Annotated bibliographies of mineral deposits in the western hemisphere. Geol. Soc. Am., Mem. 131.

Roberson, C. E. \& Barnes, R. B. 1978: Stability of fluoride complex with silica and its distribution in natural water systems. Chem. Geol. 21: 239-256.

Roberson, C. E. \& Hem, J. D. 1968: Activity product constant of cryolite at $25^{\circ} \mathrm{C}$ and one atmosphere using selective-ion electrodes to estimate sodium and fluoride activities. Geochim. Cosmochim. Acta 32: 1343-1351.

Roberson, C. E. \& Hem, J. D. 1973: Solubility of cryolite at $25^{\circ} \mathrm{C}$ and 1 atmosphere pressure. U.S. Geol. Surv., J. Res. 1: $483-485$.

Robinson, W. C. \& Edgington, G. 1946: Fluorine in soils. Soil Sci. 61: 341-355.

Romo, L. A. \& Roy, R. 1957: Studies of the substitution of $\mathrm{OH}^{-}$by $\mathrm{F}^{-}$in various hydroxylic minerals. Am. Mineral. 42: 165-177.

Rub, M. G. 1960: Granitic rocks of the Khanka Lake region and their basic metalliferous characteristics. Tr. Inst. Geol. Rudn. Mestorozhd., Petrogr., Mineral. i Geokhim. 33: 3-357.

Rub, M. G. 1972: The role of the gaseous phase during the formation of ore-bearing magmatic complexes. Chem. Geol. 10: 89-98.

Sabina, Ann P. 1976: The Francon quarry, a mineral locality. Geol. Surv. Can., Pap. 76-1B: 15-19.

Sabina, Ann P., Jambor, J. L. \& Plant, A. G. 1968: Weloganite, a new strontium, zirconium carbonate from Montreal Island, Canada. Can. Mineral. 9: 468-477.

Scheerer, T. 1854: Ueber Pseudomorphosen, nebst Beiträgen zur Charakteristik einiger Arten derselben. Ann. Phys. Chem. 92: 612-623.

Semenov, E. I. 1969: Mineralogy of the Ilimaussaq Alkaline Massif. Nauka, Moscow, 165 pp. (in Russian).

Semmens, B. \& Meggy, A. B. 1966: Reaction of kaolin with fluorides. I. Effect of neutral and acid sodium fluoride solutions. J. Appl. Chem. 16 (4): 122-125.

Sharp, W. N. 1970: Extensive zeolitization associated with hot springs in Central Colorado. U.S. Geol. Surv, Prof. Pap. 700-B: B14-B20.

Shawe, D. R. \& Van Alstine, R. E. 1976: Geologic environments and distribution of fluorine. In: D. R. Shawe (Editor), Geology and resources of fluorine in the United States. U.S. Geol. Surv., Prof. Pap. 933: 17-22.

Shcherba, G. N. 1970: Greisens. Int. Geol. Rev. 12 (2): $114-150$ and 12 (3): 239-255. 
Sheppard, R. A. \& Gude, A. J., 3d 1969: Authigenic fluorite in Pliocene lacustrine rocks near Rome, Malheur County, Oregon. U.S. Geol. Surv., Prof. Pap. 650-D: D69-D74.

Simpson, E. S. 1920: On gearksutite at Gingin, Western Australia. Mineral. Mag. 19: 23-39.

Smith, G. I. 1979: Subsurface stratigraphy and geochemistry of late Quaternary evaporites, Searles Lake, Calif. U.S. Geol. Surv., Prof. Pap. 1043; 1-130.

Smith, G. I. \& Haines, D. V. 1964: Character and distribution of nonclastic minerals in the Searles Lake evaporite deposit, California. U.S. Geol. Surv., Bull. 1181-P: 58 pp.

Smolyaninov, N. A. \& Isakov, E. P. 1958: New alumocalcium fluorides. D. S. Belyankin Jubilee Vol., Acad. Sci. U.S.S.R. pp. 145-151 (in Russian).

Smol'yaninova, N. N. 1966: Morphology of creedite crystals in some central Kazakhstan deposits. Tr. Mineral. Muz., Akad. Nauk S.S.S.R. 17: 134-149 (in Russian).

Soloviev, A. T. \& Levando, E. P. 1958: Gearksutite from easten Transbaikalia. Dokl. Akad. Nauk, S.S.S.R. 119: 158-160 (in Russian).

Sotnikov, V. I., Berzina, A. \& Kuznetsova, I. K. 1971: Fluoride minerals of the Sor deposit and their genesis. Mater. Genet. Eksp. Mineral. 6: 123-130 (in Russian).

Stavrov, O. D. \& Bykova, T. A. 1961: Distribution of some rare and volatile elements in the rocks and pegmatites of the Korosten'skii pluton. Geochemistry 370-374.

Steacy, H. R. \& Jambor, J. L. 1969: Nature, distribution and content of zirconium and niobium in a silico-carbonatite sill at St-Michel, Montreal Island, Quebec. Geol. Surv. Can., Pap. 69-20: 7 pp.

Stefánsson, K. \& Sigurjónsson, J. 1957: Temporary increase in fluorine content of water following the eruption. In: T. Einarsson, G. Kjartansson \& S. Thorarinsson (Editors), The eruption of Hekla 1947-1948. Visindafelag Isl., (Rit) 3 (1/3): 13 pp.

Stepanov, V. I. 1963: Cryolite. In: F. V. Chukhrov \& E. M. Bonshtedt-Kupletskaya (Editors), Minerals. Vol. Il, Part 1. Halogenides. Akad. Nauk S.S.S.R., Moscow, pp. 39-50 (in Russian).

Stepanov, V. I. \& Moleva, V. A. 1962: On the ralstonite from Ilmen Mountain, central Kazakhstan and Kamchatka. Zap. Vses. Mineral. Ova. 91 (5): 556-572 (in Russian).

Stepanov, V. I. \& Severov, E. A. 1961: Gagarinite - A new rare-earth mineral. Dokl. Acad. Sci. U.S.S.R., Earth Sci. Sect. 141: 1290-1293.

Stepanov, V. I. \& Sokolova, M. N. 1963: Ralstonite. In: F. V. Chukhrov \& E. M. Bonshtedt-Kupletskaya (Editors), Minerals. Vol. II, Part 1. Halogenides. Akad. Nauk S.S.S.R., Moscow, pp. 55-60 (in Russian).

Stevenson, J. S. \& Stevenson, L. S. 1975: Fluorite-dawsonite relationships at a new Montreal locality. Can. Mineral. 13: 313.

Stinton, D. P. \& Brown, J. J., Jr. 1975: Phase equilibria in the system $\mathrm{Na}_{3} \mathrm{AlF}_{6}-\mathrm{Li}_{3} \mathrm{AlF}_{6}$. J. Am. Ceram. Soc. 58: 257.

Stoiber, R. E. \& Rose, W. I., Jr. 1969: Recent volcanic and fumarolic activity at Santiaguito volcano, Guatemala. Bull. Volcanol. 33: 475-502.

Stoiber, R. E. \& Rose, W. I., Jr. 1974: Fumarole incrustations at active Central American volcanoes. Geochim. Cosmochim. Acta 38: 495-516.

Stormer, J. C. \& Carmichael, I. S. E. 1970: Villiaumite and the occurrence of fluoride minerals in igneous rocks. Am. Mineral. 55: 126-134.

Strakhov, N. M. \& Borneman-Starynkevich, I. D. 1946: On strontium, boron, and bromine in the rocks of the Lower Permian halogenic series of Bashkirian suburalian district. In: Problems in Mineralogy, Geochemistry and Petrography. Fersman Memorial Volume. Akad. Nauk S.S.S.R., Moscow and Leningrad, pp. 262-274 (in Russian).
Sugiura, T., Mizutani, Y. \& Oana, S. 1963: Fluorine, chlorine, bromine and iodine in volcanic gases. J. Earth Sci., Nagoya Univ. 11: 272-278.

Sæbø, P. C. 1966: A short comment on some Norwegian mineral deposits within the Igneous Rock Complex of the Oslo Region. Nor. Geol. Tidsskr. 46: 260-261.

Sørensen, H., Leonardsen, E. S. \& Petersen, O. V. 1970: Trona and thermonatrite from the Ilímaussaq alkaline intrusion, South Greenland. Bull. Geol. Soc. Den. 20: 1-19.

Tischendorf, M. I. 1973: The metallogenetic basis of tin exploration in the Erzgebirge. Trans. Inst. Min. Metall. Sec. B, 82: B9-B24.

Tolstoy, M. I., Ostafiychuk, I. M. \& Molyavko, V. G. 1973: Geochemical characteristics of granitoids of the Korosten'sk intrusive complex, Ukrainian shield. Geochem. Int. 10: $1215-1232$.

Turekian, K. K. 1969: The oceans, streams, and atmosphere. In: K. H. Wedepohl (Editor), Handbook of Geochemistry, Vol. I, Chapter 10.

Tuttle, O. F. \& Bowen, N. L. 1958: Origin of granite in the light of experimental studies in the system $\mathrm{NaAlSi}_{3} \mathrm{O}_{8}-\mathrm{KAl}$ $\mathrm{Si}_{3} \mathrm{O}_{8}-\mathrm{SiO}_{2}-\mathrm{H}_{2} \mathrm{O}$. Geol. Soc. Am., Mem. 74: $153 \mathrm{pp}$.

Ulrych, T. J. 1964: The anomalous nature of Ivigtut lead. Geochim. Cosmochim. Acta 28: 1389-1396.

Upton, B. G. J. 1974: The alkaline province of south-west Greenland. In: H. Sørensen (Editor), The Alkaline Rocks. Wiley, London, pp. 221- 238.

Viramonte, J. G., Sureda, R. J., Bossi, G. E., Fourcade, N. H. \& Omarini, R. H. 1976: Geochemical and mineralogical study of the high temperature fumaroles from Deception Island, South Shetland, Antarctic. In: O. Gonzales Ferran (Editor), Proceedings of the Symposium on "Andean and Antarctic Volcanology Problems." Francesco Giannini \& Figli, Napoli, pp. 543-561.

Vlasov, K. A. 1966: Geochemistry and mineralogy of rare elements and genetic types of their deposits. Vol. III Genetic types of rare-element deposits. Acad. Sci., U.S.S.R., Moscow (Translated 1968, Israel Program for Scientific Translations, Jerusalem).

Vlasov, K. A., Kuzmenko, M. V. \& Eskova, E. M. 1959: The Lovozero Alkaline Massif. Akad. Nauk S.S.S.R., Moscow (in Russian). (Translated 1966, The Lovozero alkali massif. Oliver \& Boyd, Edinburgh).

Von Eckerman, H. 1948: The alkaline district of Alnö Island. Sver. Geol. Unders. Ser. Ca, No. 36.

Von Platen, H. 1965: Kristallisation granitischer Schmelzen. Beitr. Mineral. Petrogr. 11: 334-381.

Voskrenskaya, I. E. 1976: Phase transformation in experiments on tourmaline synthesis. L'vov Gos. Univ. Mineral. Sb. 30 (1): 14-17.

Voznyak, D. K. 1971: Primary inclusions in Volynian topaz. In: V. A. Kalyuzhnyi (Editor), Mineral-forming fluids and paragenesis of minerals of pegmatites of the "chamber" type in the Ukraine. Naukova Dymka Press, Kiev, pp. 73-81 (in Ukrainian).

Weil, R., Siat, A. \& Fluck, P. 1975: Unpublished or rare mineral species of the Vosges. Sci. Geol., Bull., Inst. Geol., Univ. Louis Pasteur Strasbourg 28 (4): 261-282.

White, D. E. 1957: Magmatic, connate, and metamorphic waters. Bull. Geol. Soc. Am. 68: 1659-1682.

White, D. E. \& Waring, G. A. 1963: Volcanic emanations. In: Data of Geochemistry, 6th Edition. U.S. Geol. Surv., Prof. Pap. 440-K, Ch. K., pp. KI-K29.

Williams, F. A., Meehan, J. A., Paulo, K. L., John, T. V. \& Rushton, H. G. 1956: Economic geology of the decomposed columbite-bearing granites, Jos Plateau, Nigeria. Econ. Geol. 51: 303-322.

Winkler, H. G. F., Boese, M. \& Marcopoulos, T. 1975: Low temperature granitic melts. Neues Jahr. Mineral. Monatsh. 6: $245-268$. 
Wittheft, B. W. 1936: Preliminary results of the expedition of the Geological Section of the Far Eastern Department of the Academy of Science in 1935. Report of the Far Eastern Department of the Academy of Science of the USSR. 17: 87-94. Vladivostok (in Russian).

Wolfbauer, C. A. 1971: Geologic framework of the Green River Formation in Wyoming. Contrib. Geol, Univ. Wyo. $10(1): 3-8$.

Wright, J. B. 1970: Origin of the Younger Granites of Northern Nigeria by P. Bowden. Contr. Mineral. and Petrol. 25, 153-162 (1970). Contrib. Mineral. Petrol. 29: 89-90.

Wyllie, P. J. 1966: Experimental studies of carbonatite problems. In: O. F. Tuttle \& J. Gittin (Editors), Carbonatites. Interscience, New York, pp. 311-352.

Wyllie, P. J. \& Tuttle, O. F. 1961: Experimental investigation of silicate systems containing two volatile components, II. The effects of $\mathrm{NH}_{3}$ and $\mathrm{HF}$, in addition to $\mathrm{H}_{2} \mathrm{O}$, on the melting temperatures of albite and granite. Am. J. Sci. 259: 128-143.

Yurk, Yu. Yu., Gurov, Ye. P. \& Gurova, Ye. P. 1970: First occurrence of thomsenolite in the Ukraine. Dopov. Akad. Nauk Ukr. R.S.R. Ser. B, 5: 408-410 (in Ukrainian).

Yurk, Yu. Yu., Gurov, Ye. P. \& Gurova, Ye. P. 1974: Genesis of cryolite in metasomatic rocks of the Ukrainian Shield. Dokl. Acad. Sci. U.S.S.R., Earth Sci. Sect. 208: 143-145.
Zakharchenko, A. I. 1971: On time and physico-chemical conditions of mobilization, transport and precipitation of tungsten and tin in postmagmatic processes (exemplified by intragranitic chamber pegmatites). In: Mineralogy and geochemistry of tungsten deposits (Materials of 2nd All-Union Symposium on Mineralogy, Geochemistry and Genesis of Tungsten Deposits of USSR). Leningrad Univ. Publishing House, Leningrad, pp. 287-306 (in Russian). Extended abstract in English in Fluid Inclusion Research: Proceedings of COFFI 6: 191-194.

Zarayskiy, G. P. \& Zyryanov, G. P. 1973: Experimental studies of alkaline metasomatism of granites. In: V. A. Zharikov et al. (Editors) Contributions to Physico-Chemical Petrology. Vol. 3. Nauka, Moscow, pp. 119-156 (in Russian).

Zavaritsky, A. N. 1939: Geological and petrographical sketch of llmen mineralogical reservation and its mines. Main department of reservations, Moscow, 315 pp (in Russian).

Zavaritsky, A. \& Kryjanovsky, W. 1937: Ilmen State Mineralogical Reservation. Congr. Geol. Int., XVII Sess., USSR. Uralian Excursion - southern part, pp. 5-17.

Zinchenko, O. V. 1968: On a find of accessory cryolite in the Perzhansky granites (Volhynia). L'vov Gos. Univ. Mineral. $S b .22$ (3): 304-308 (in Russian). 